Portland State University

PDXScholar

$5-9-2008$

\title{
"Whose streets? Our streets!" Urban Social Movements and the Transformation of Everyday Life in Pacific Northwest Cities, 1990-1999
}

Leanne Claire Serbulo

Portland State University

Follow this and additional works at: https://pdxscholar.library.pdx.edu/open_access_etds

Part of the Civic and Community Engagement Commons, Public Policy Commons, Urban Studies Commons, and the Urban Studies and Planning Commons

Let us know how access to this document benefits you.

\section{Recommended Citation}

Serbulo, Leanne Claire, "'Whose streets? Our streets!" Urban Social Movements and the Transformation of Everyday Life in Pacific Northwest Cities, 1990-1999" (2008). Dissertations and Theses. Paper 737.

https://doi.org/10.15760/etd.737

This Dissertation is brought to you for free and open access. It has been accepted for inclusion in Dissertations and Theses by an authorized administrator of PDXScholar. Please contact us if we can make this document more accessible: pdxscholar@pdx.edu. 


\section{DISSERTATION APPROVAL}

The abstract and dissertation of Leanne Claire Serbulo for the Doctor of Philosophy in Urban Studies were presented May 9, 2008, and accepted by the dissertation committee and the doctoral program. COMMITTEE APPROVALS:
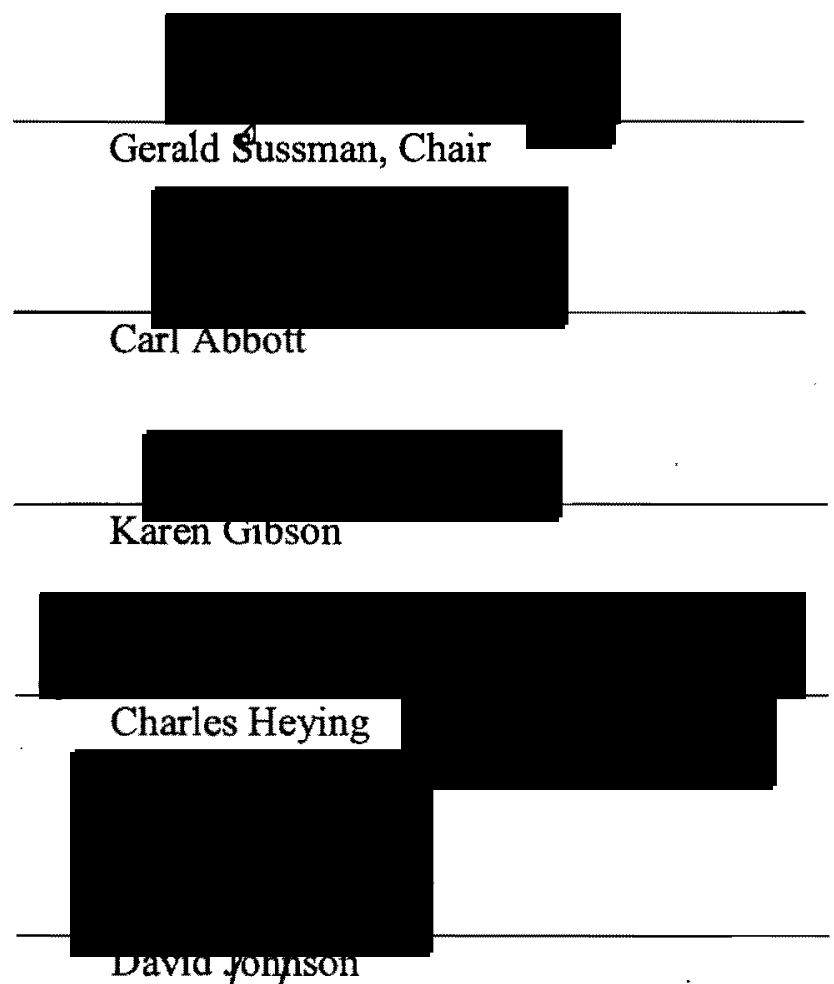

Representative of the Office of Graduate Studies

DOCTORAL PROGRAM APPROVAL:

Anthony Rufolo, Director

Urban Studies Ph.D. Program 


\begin{abstract}
An abstract of the dissertation of Leanne Claire Serbulo for the Doctor of Philosophy in Urban Studies presented May 9, 2008.
\end{abstract}

Title: "Whose streets? Our streets!" Urban social movements and the transformation of everyday life in Pacific Northwest cities, 1990-1999

This project returns to the questions that were once at the center of the urban studies debate over social movements. What are urban social movements, and what impacts do they leave on the cities where they occur? Urban protests in Portland, Oregon and Seattle, Washington are used as the foundation for exploring the following research questions: What urban social movements occurred in the Pacific Northwest during 1990s? What goals were these movements struggling for? What impacts did urban social movements have on daily life in Portland and Seattle?

While this project has continuity with earlier attempts to identify, describe, and assess the role that urban social movements play in cities, it also represents a significant departure from the established ways of understanding this phenomenon. Manuel Castells' (1983) theory on urban social movements considered local activism ineffectual, if it could not produce serious revolutionary change. A different portrait of urban social movements emerged in this project. Pacific Northwest urban protests 
challenged existing social relationships in neighborhoods, at work, in public services, in the construction and use of urban space, and in the imagination of the city. These protests grew out of the everyday life experiences of their participants and sought to transform the patterns and relationships of daily life.

Since urban social movements arise from everyday life, their impacts will be evident in a community's use of time, construction of space, development of social relationships, and sense of possibility. The ability of urban social movements to radically alter the everyday lives of their participants and communities of interest is, in and of itself, significant. As these changes reverberate beyond the boundaries of these directly impacted communities, they have the potential to create broader citywide changes. It is these transformations that are the building blocks for the active construction of our urban cultures, spaces, and communities. 


\title{
"WHOSE STREETS? OUR STREETS!" \\ URBAN SOCIAL MOVEMENTS AND THE TRANSFORMATION \\ OF EVERYDAY LIFE IN PACIFIC NORTHWEST CITIES, 1990-1999
}

\author{
by \\ LEANNE CLAIRE SERBULO
}

A dissertation submitted in partial fulfillment of the requirements for the degree of
DOCTOR OF PHILOSOPHY
in
URBAN STUDIES

Portland State University

2008 


\section{TABLE OF CONTENTS}

$\begin{array}{lc} & \text { Page } \\ \text { List of Tables } & \text { ii } \\ \text { List of Figures } & \text { iii } \\ \text { Preface } & \text { iv }\end{array}$

Part One "Whose Streets?" The City, the Grassroots 1

and the Meaning of Local Protest

Chapter One The Study of Urban Social Movements 2

in the Pacific Northwest: An Introduction

Chapter Two The Urban Social Movement Revisited:

A Literature Review

Chapter Three What Are Urban Movements and How

Do They Matter: Research Questions and Methodology

Chapter Four Urban Social Movements in a Global

and Regional City: A Decade of Local Protest in the

Pacific Northwest 1990-1999

Chapter Five The Urban Social Movement and

Everyday Life

Part Two "Out Streets!" The Impacts of Urban Social

Movements on Everyday City Life

Chapter Six How Urban Social Movements Matter:

Measuring Their Impacts on Everyday Life

Chapter Seven Stories of Protest in the Pacific Northwest:

Five Urban Movements from the 1990s

Chapter Eight The Impacts of Urban Social Movements on Everyday City Life

References 


\section{LIST OF TABLES}

\section{$\underline{\text { Page }}$}

Table 4-1 Protest in the Pacific Northwest 1990-1999

Table 4-2 Urban Protest in the Pacific Northwest 1990-1999

Table 5-1 Five Aspects of Everyday Life Evident in

Pacific Northwest Protests 1990-1999

Table 5-2 Characteristics of Protest in Each of the Five

Aspects of Everyday Life

Table 8-1 The Impacts of Urban Social Movements on

Everyday Life 


\section{LIST OF FIGURES}

\section{$\underline{\text { Page }}$}

Figure 4-1 Categories of Urban Protest: Portland and 58

Seattle, 1990-1999

Figure 6- $I$ Communities Impacted by Urban Movements

Figure 8-1 The Interaction of Everyday Life Variables 152 in Urban Social Movements

Figure 8-2 Urban Movement Impacts Beyond the Boundaries of Community 


\section{PREFACE}

While I was writing this dissertation, the school district announced plans to demolish my children's elementary school. Our neighborhood school sits in the path of an expanding private college campus. The school district has a history of closing schools in our community, promising new facilities, but never building them. My children love their school, because it is a small, supportive community. If this dissertation were not completely dominating my life, I would have worked with parents, teachers, community members, and students to launch an organized response to the district's plan. This situation is a living example of how urban movements are made. Our everyday lives are threatened by institutional forces and we respond in the only way we can, by organizing. The strong, multicultural community my family has been an active part of for the past five years might soon disappear, and protest is the only way I know to stop that.

Sixteen years ago, I took part in an occupation of a vacant building in downtown Seattle. For almost a week, 200 homeless and housed people camped out in the Pacific Hotel. A few months later, this building was turned into permanent affordable housing. That victory showed me the power of direct action and protest. When people get together, we can overcome seemingly impossible odds.

After the occupation, my friends and I started a free food program where we fed 300 homeless people every Sunday. In spite of the fact that most of us were squatting or homeless, we managed to sustain that program for over four years. We 
started off intending to make a political statement by serving in the parks where the police had banned food programs, but soon realized that serving a plate of food with politics was no different than serving soup with a sermon. We moved to a safer park and spent week after week preparing tasty, nutritious food and serving it with respect and dignity for those were eating. Soon, those we fed starting taking ownership of the project, and we worked side by side each Sunday. The relationships I built with people in the park each week completely transformed how I saw my city. I couldn't walk downtown without running into someone whom I knew on the streets. The parks, the library, and public squares became places to meet and socialize with the homeless community. For me, the streets of Seattle were the safest place in the city. Experiences as dramatic as the Pacific Hotel occupation, and as mundane as my conversations with my homeless friends in the park, inspired this research project. I have been participating in urban social movements for a long time, and I wanted to understand how the mechanisms of urban social change work. How can a militant, organized effort by hundreds of people and a simple act by a few marginalized souls both completely transform my city? If I could become conscious of the role and potential these actions have for creating social change, I could become a better advocate for a more just, equitable and democratic city.

Just like any social movement requires many heads and hands, this research project was in many ways a collaborative effort. Without the generous support and cooperation of numerous people, this project would have never come to fruition. I am 
grateful to all of my committee members who offered insightful comments and continued encouragement. Dr. Gerry Sussman was especially supportive. $\mathrm{He}$ remained patient through my many grammatical errors and was always willing to talk through any theoretical dilemmas. A special thanks to Dr. Karen Gibson for giving such detailed feedback. She is my mentor and more importantly, my friend, and I would like to thank her for everything she has done.

Thanks to the activists who shared their stories with me. You are an inspiration. Thanks to my family: to my mom who instilled the values of compassion and consideration in all of us, and to my sisters who I can always count on. Thanks to my children, Arabella and Emiliano, for putting up with a distracted mom and for knowing when and how to make me smile. You amaze me each and every day, give me hope, and teach me how to see the world in new ways. My deepest thanks go to my love, Jonathan, for always being there, for always believing in me, and for always standing up for what is right no matter what the cost. This is for you. 
PART ONE

"WHOSE STREETS?"

THE CITY, THE GRASSROOTS, AND THE MEANING OF LOCAL PROTEST 


\section{CHAPTER ONE \\ THE STUDY OF URBAN MOVEMENTS IN THE PACIFIC NORTHWEST: AN INTRODUCTION}

"Whose streets? Our streets!" 50,000 protesters jubilantly called out as they shut down the World Trade Organization meetings in Seattle in 1999 (Postman, Broom and King, 1999). Television viewers across the globe watched as masked anarchists used hammers to break out Nordstrom's windows, artists burned a pair of khakis in front of the Gap, and turtle-costumed activists and Teamsters marched side by side. These events became known as the "Battle of Seattle," a phrase lifted from the t-shirts a protest group started selling one week before the trade meetings (Postman and Mapes, 1999, A1). Years afterwards, commentators and scholars continue to debate the significance of the events in Seattle. One scholar argued that there is "no resisting the trend for social movements to go global," and he urged activists to "get over their nostalgia for the local" (Banks, 2000,66). Others proclaimed the Battle in Seattle was an inevitable response to neoliberal globalization, and it signaled the new "internationalization of protest" (Brand and Wissen, 2005, 9).

These commentators seemed to heed the words of Seattle Mayor Paul Schell who pleaded in midst of the battle, "Be tough on your issues but be gentle on my town" (Postman et al., 1999, A1). In all of the scholarly articles published about this watershed event, not a whisper was made about the city these protests took place in. Long before the streets of Seattle became a battlefield, protesters used marches, rallies, sit-ins, occupations, and occasionally, riots to create change in that city. On the day that protesters shut down the World Trade Organization meetings, Seattle cab drivers 
were staging a one-day strike (Postman et al., 1999). One hundred and fifty drivers stayed off the downtown streets, adding to the mayhem that day. The cab drivers were protesting a city ordinance that required them to wear uniforms and identification badges and levied steep fines on taxis while the limousine and town car industries remained unregulated. Drivers felt the city had "thumbed their noses" at the cabbies, and they decided to strike (Robin, 1999, A22). Yet no social movement analysts remarked on the impact that the cab drivers strike had on the Seattle labor movement or the city in general. Social movement scholarship was enamored with the new transnational forms of activism, so when locally-based mobilizations occurred, they went comparatively unnoticed and under-theorized (Della Porta and Tarrow, 2005).

This project examines the decade of local protests that preceded the WTO events in two major Pacific Northwest cities and analyzes how those movements shaped daily urban life. Rather than looking at transnational protests, the focus is on urban-level activism. Local movements enjoyed a brief heyday in the social science literature. The riots that shook U.S. cities in the late 1960s, the May 1968 Paris rebellion that spread across Europe, and the rise of the squatters' movements throughout Latin America in the 1970s roused scholarly attention to the possibilities of urban movements. These events sparked a vigorous debate about the relationship between movements, social change, and cities as well as discussion about the revolutionary potential of urban-based activism (Fainstein and Fainstein, 1974; Castells, 1977; Castells, 1983; Lowe, 1986). 
This study returns to the questions that were once at the center of the urban studies debate around social movements: What are urban social movements, and what impacts do they leave on the cities where they occur? Urban protests in Portland, Oregon and Seattle, Washington are used as the foundation for exploring the following research questions:

- What urban social movements occurred in the Pacific Northwest during 1990s?

- What goals were these movements struggling for?

- What impacts did urban social movements have on daily life in Portland and Seattle?

\section{What are urban social movements and how should they be studied?}

Social movements are easy to identify but difficult to define. Movement scholar, Charles Tilly (2004) avoided the using the term social movement, because of its amorphous meaning. Finally, after decades of writing on the subject, Tilly came up with three criteria that mobilizations must meet in order to be considered a social movement. Movements consist of sustained campaigns that engage in a repertoire of public performances to display their worthiness, unity, numbers, and commitment to a cause (Tilly 2004, 3). Campaigns refer to the multiple events that are organized by diverse collectivities of groups and individuals. Social movement repertoires include protest, meetings, vigils, electoral campaigns, press conferences, and sometimes street fighting or property damage. The purpose of these actions is to convince others of the righteousness of a particular position or cause. Donatella Della Porta and Mario Diani (1999) offer a similar definition. Social movements are informal networks of 
organizations and individuals whose participants share deeply held beliefs. These networks are involved in social conflicts over their beliefs. They use protest, and other forms of collective action, to express their positions and to engineer social change.

Urban social movements display all of these characteristics; what makes them distinct from other forms of contentious action is the geographic scope of their concerns and the scale on which they are organized (Lake, 2006). Urban movements can be distinguished from other levels of mobilization because they are organized by locally based groups, inspired by city events, and aim towards making urban-level changes (Nicholls and Beaumont, 2004). Not every demonstration that winds through a city's downtown streets is part of an urban social movement. Some protesters base their movements "in the city" while trying to create national or international scale change (Fontan, Hamel, Morin and Shragge, 2007). The "Battle of Seattle" was fought to change international trade relationships. It happened to take place in Seattle, but the movement later repeated these protests in Cancun and Genoa. Urban social movements are organized to create changes "on the city" (Fontan et al., 2007).

The purpose of this project is to identify the movements that happened "on the city" in Portland, Oregon and Seattle, Washington during the 1990s and to evaluate how they impacted daily urban life in the Pacific Northwest. A protest event analysis was conducted to identify these movements,. Protest event analysis is a research method that uses newspaper and media reports to collect data about the campaigns of a particular social movement or to measure the density of movement activity in a 
specific place, during a certain historical moment (Koopmans and Rucht, 2002). A protest event analysis was used to answer the research question: What urban social movements occurred in Portland and Seattle during the 1990s? The events were also analyzed to determine if they took place "in the city" or were directed "on the city" (Fontan et al., 2007). In order to be considered an urban protest, the event had to be locally organized, driven by community events or directed at a city institution (Nichols and Beaumont, 2004). Three-hundred and three, or $44 \%$ of all of the events, were urban protests.

What goals were urban protesters fighting for in these more than three hundred events? To answer this question, a narrative analysis was used. Bits and pieces of protesters' narratives were stitched together from the newspaper reports of events. These snippets were drawn from quotes of interviewed protesters, chants, press release statements, slogans, and actions that were recorded in the event articles. Through protesters' narratives, the goals and meaning of urban social movements were discovered. Additionally, these narratives were used to test the explanatory relevance of existing urban social movement theory. When this theory failed to capture the scope of urban protest in Portland and Seattle, the narrative data were analyzed to construct an alternative explanation of the role that urban social movements play in cities.

Protesters' stories revealed that urban social movements in the Pacific Northwest organized to transform the everyday lives of their constituents. Everyday life refers to the taken-for-granted routines that we participate in, from work to family 
life to leisure activities (Lefebvre, 2005a; 2005b; 2005c). Protesters contested five aspects of everyday urban life: labor, collective consumption, neighborhood, urban space and imagination. Protesters wanted to change the social relationships within their cities, and they did so by organizing around issues in their workplace, neighborhoods and within the public goods and services they consumed. Movements also fought for the right to occupy public space and to determine who the built environment would be designed for and serve. Finally, protesters struggled to be included in the collective identity of the city.

The last research question asked how urban movements transformed daily life in Portland and Seattle during the 1990s. Urban movement impacts were analyzed at the community level. All urban movements identify constituencies, or communities of interest (DeFillipis and North, 2004). Five mini-case studies were conducted to answer the question: How did urban movements impacted the daily lives of their communities of interest in Portland and Seattle? One case study movement was chosen from each of the five aspects of daily urban life that protesters contested in the Pacific Northwest: labor, collective consumption, neighborhood, urban space and imagination. To be selected as a case, each of these protest events had to meet the basic criteria that define a social movement. According to Tilly (2004), social movements are not only distinguished by their public protest performances, they also must be able to sustain a diverse campaign over a prolonged period of time. Only movements that had multiple protest events attributed to them were considered. In 
addition, these protests had to take place over a period of months or years, and have more than one organization associated with their actions.

The five case study movements chosen were the Hotel Workers' Organizing Committee, the Black United Front's school boycotts, the coalition against Weed and Seed, Operation Homestead's building takeovers, and the Rose Festival pageant protests. The Hotel Workers' Organizing Committee (HWOC) contested the working conditions that low-wage immigrant workers faced in Portland. The Black United Front organized for racial equality in the provision of educational services in Portland. Neighbors in Seattle's Central District fought the Weed and Seed federal policing program that targeted their community. Operation Homestead led numerous building takeovers in downtown Seattle to ensure poor people's right to live in an increasingly expensive community. High school students challenged the portrayals of women in the annual Rose Festival Princess pageant.

Four criteria were developed to assess how these movements impacted the daily lives of their communities of interest. These criteria originated in Henri Lefebvre's philosophical writings on the organization of everyday life (Lefebvre, 1991; 2005a; 2005b; 2005c). The criteria included: time, space, social relationships, and sense of possibility. Not only did the five case study movements change the daily routines of their communities, they also constructed alternative spaces in the city. These movements forged new social relationships and communities, and they communicated a sense of hope and possibility to their constituencies. Occasionally, urban movement impacts rippled out beyond their immediate communities and 
changed everyday life in larger communities or beyond the borders of the cities they took place in.

\section{Studying Protest in the Urban Pacific Northwest}

Portland and Seattle are ideal sites for studying urban protest. The Pacific Northwest region lies along the northern edge of the United States' politically progressive "Left Coast" (DeLeon, 1992). Both Portland and Seattle are recognized for their high levels of neighborhood activism and civic engagement (Berry, Portney and Thomson, 1993; Diers, 2004; Ozawa, 2004). During the 1990s, these two cities briefly earned notoriety for their rowdy protests. At the beginning of the decade, Portland was rocked by a series of unruly demonstrations that coincided with the visits of President George H.W. Bush and Vice President Dan Quayle to the city. After the third raucous protest, the White House nicknamed the city "Little Beirut" (Mapes, 1990, A1). By the end of the 1990s, it was Seattle that captured the headlines as protesters took over the downtown streets and shut down the World Trade Organization meetings (Postman et al., 1999).

In between these well-publicized events, many smaller protests occurred. These protests targeted the specific living conditions and political situations in Portland and Seattle. The Pacific Northwest may not seem like the best case for studying urban movements in the United States. Portland and Seattle rarely make any list of world cities (Sassen, 1991). While protests like the Tompkins Square Park riots in New York get national acclaim, the locally-based movements in the Pacific Northwest are basically unknown outside of the region (Smith, 1996). However, this 
very commonplace nature of Pacific Northwest movements make them the perfect case for studying the role that collective action plays in shaping the everyday lives of city dwellers. These are ordinary cities, where ordinary movements take place.

In addition to their ordinary features, Portland and Seattle were chosen because access to movement activists and adequate information were available for these cases. Informational availability is an appropriate rationale for selecting a case (Flyvbjerg, 2006). As a participant in various urban social movements in both Portland and Seattle during the 1990s, I have a strong base of knowledge about the local protest scene, access to some area activists, and a personal understanding of inner workings of grassroots organizations. I made a conscious effort to avoid studying movements that I was intimately involved with. In the fall of 1992, I participated in the Operation Homestead's occupation of the Pacific Hotel in Seattle, but I was not involved in the organizing or decision-making processes that led to this action.

The issues that urban movements in the Pacific Northwest addressed may, or may not be important elsewhere in the United States, but the role that movements played in shaping the everyday lives of their immediate communities of interest are replicated in cites all over the globe. This is a study of the process of social change. It is a tale of how ordinary people in ordinary cities got together to transform the daily lives of themselves and those around them. While these changes never resulted in a total transformation of everyday urban life, they nevertheless profoundly shape the communities where they occurred in profound ways. 


\section{Contributions and Limitations of this Study}

There was vigorous debate about urban social movements during the 1970 s and 1980s (Fainstein and Fainstein, 1974; Castells, 1977; Pickvance, 1976;

Katznelson, 1981; Castells, 1983; Lowe, 1986). Urban movement scholars debated the nature and impacts of urban-based activism. By the late 1980s, the question of urban movements disappeared as theorists became increasingly concerned with global issues. Rather than discussing the role that movements played within cities, urban researchers debated the new positions that were emerging for cities in the global political economy and highlighted the limitations of localism. Even when a few contemporary scholars revived the urban movement debate, they were mainly interested in understanding how globalization created new areas of contention for local activists (Mayer, 2000; 2003; 2006). Questions about the role that urban movements play within cities were seemingly forgotten.

This study returns to the original concerns of urban movement theorists: What are urban social movements and what impacts do they have on cities? Despite the global theoretical turn, data in this project showed that local movements continue to occur and continue to matter. Urban movements made up almost half of all protest activity in the Pacific Northwest during the 1990s. Even in this decade of globalization, activists continued to try and make local, grassroots change.

These findings were discovered by systematically cataloguing all of the urban protests that occurred in Portland and Seattle. Urban movement researchers in Europe and Canada frequently use protest event analysis to study grassroots activism, but this 
method is rarely applied to U.S. cities (Rucht and Koopmans, 2002; Fontan et al., 2007). This study created one of the first catalogues of U.S. urban-specific protest activity. Although protest event analysis has been used to study other questions about U.S. movements, this is the first time this method was used to study urban movements in the United States (Rucht and Koopmans, 2002).

The debate about urban movements ended in the mid-1980s and did not resurface until the end of the 1990s (Mayer, 2000). During this hiatus, locally-based activism flew under the radar of urban and social movement theorists. The movements of the 1990s did not draw the same attention that earlier community-based activism did. The revolutionary tenor that was so prevalent in the community movements of the 1960s and 1970s had given way to a more pragmatist approach. Movements no longer claimed to be creating fundamental social changes, and as a result, researchers dismissed these efforts as "militant particularisms" that were incapable of defeating global social structures (Harvey, 1996, 168). Due to this global bias, the scope of U.S. urban movement activity in the 1990s is not well researched or understood.

Given the revolutionary intentions of the grassroots activism that originally sparked the urban social movement debate, it is not surprising that when researchers evaluated the impacts of local organizing, they looked for large-scale transformative changes (Fainstein and Fainstein, 1974; Castells, 1983). Under these criteria, the prognosis for the efficacy of urban movements was not good. For the most part, urban activists failed to transform state and national politics or to change the role and 
functions of the cities they took place in. This study shows that despite earlier rhetoric, the purpose of urban movements is not to create larger-scale revolutionary social change. Urban movements are sparked by and organized around issues of everyday city life. These movements want to change the ways in which urban dwellers lead their everyday lives and need to be evaluated accordingly.

This project identified the impacts that urban movements make within cities, rather than beyond them. Movement impacts were evaluated at the level of protesters' immediate "communities of interest," or their stated constituencies (DeFillipis and North, 2004). Theorists had previously examined movement impacts either on individual protest participants or on local, state, national, or international political structures (Melucci, 1989; Giugni, 1999). Examining the daily life routines of a community within a city creates an alternative scale by which the transformative impacts of urban social change can be evaluated.

The five case study movements in this project created changes in the daily lives of their constituencies. All of these movements introduced new possibilities for organizing daily life, and most transformed existing social relationships or formed new communities. All of these movements made modifications to the daily routines of their constituents, although some of these changes were temporary. Many of these movements were able to transform urban space and subsequently created more permanent alterations to urban dwellers' daily routines.

The changes that urban movements made in Portland and Seattle were not limited to their immediate communities. Some movements failed to create a 
significant local impact but were able to influence activists in other places. Other movements made such a strong local impact that their transformations echoed out beyond the barriers of their immediate communities and into the city as a whole.

This study argues for a wholesale reconsideration of the role that urban movements play in cities. These movements need to be understood from an everyday life perspective. The concept of everyday life encompasses all of our taken-forgranted daily rhythms and routines (Lefebvre, 2005a; 2005b; 2005c). Everyday life is both a product and residue of the capitalist system. An everyday life perspective examines meta-institutions and social relationships from an experiential point of view. Looking at movements from the standpoint of daily life requires that attention be paid to the differences among various movements across places, cultures, and time. The lack of attention to cross-cultural and historical differences is one of the limitations of this research. While Portland and Seattle provide a glimpse of the social movement processes at work in two different cities, these places still share a common geography, demographic and history. How are urban movements manifested in places outside the Pacific Northwest? The five aspects of everyday life that movements contested in the Pacific Northwest may not translate to other places or in different historical eras. More research is needed to contextualize the role and impacts that urban movements have on cities.

This study also indicates that urban movements have the potential to create changes beyond the boundaries of their immediate communities and outside of the borders of their cities, but it fails to outline the exact preconditions and processes that 
spark these changes that can transcend beyond the community-scale. Social movement researchers identified and discuss how movement diffuse across space and time, but more research is needed to see how these mechanisms work on the urban scale (Della Porta and Diani, 1999).

\section{Outline of the study}

This study opens with a review of the brief literature on urban social movements. Chapter Two explores the key debates that occurred over what constitutes an urban movement and how these grassroots actions change cities. Chapter Three discusses the gaps in this literature and outlines the basic research questions, methodologies, and concepts that were used in this project. Chapter Four introduces the results from the protest event analysis of the two cities. The general circumstances of protest in each city are discussed and analyzed. Urban movements are then separated from the larger catalogue of protest, described, and contextualized in each city. Chapter Five addresses the research questions about urban movements' goals and meaning. When the existing urban social movement theory fails to explain these Pacific Northwest protests, a new theory built around the concept of everyday life.

The second section of the study is devoted to the question of urban movement impacts. Chapter Six outlines the framework that was used to analyze urban movement impacts from the perspective of everyday life. Chapter Seven tells the stories of the five case-study movements. Chapter Eight discusses the results of the analysis of urban movement impacts. The impact of these five case study movements 
on the construction of time, space, social relationships, and sense of possibility within their communities of interest is described, and the interaction of these four variables is explored. Urban social movements are considered in their broader context, as well. The diffusion of these impacts beyond their communities and into the city as a whole is examined. This chapter concludes with a reflection on how the lessons learned from this study can be applied to urban theory and adapted to create more equitable and just cities in the Pacific Northwest and beyond. 


\section{CHAPTER TWO \\ THE URBAN SOCIAL MOVEMENT REVISITED: \\ A LITERATURE REVIEW}

During the late 1960 s, cities were alive with protest. Fires burned in Watts as residents rose up against police brutality, slum living conditions and entrenched racism. Parisians built barricades and workers and students united with cries of "Change life! Change society!" (Lefebvre, 1991, 59) Chileans marched through the streets of Santiago to demand justice for urban and rural laborers. Urban theorists witnessed, and occasionally joined, these popular movements then began to construct theories that explained the role that protest played in transforming cities (Fainstein and Fainstein, 1974; Castells, 1977; Katznelson, 1981; Castells, 1983; Lowe, 1986). A literature arose around the concept of the urban social movement. Scholars explored the potential that these urban-based social movements had for igniting broader, fundamental change. The urban social movement field developed separately from social movement studies, an emerging sub-discipline in sociology. Sociologists were primarily interested in the processes of movement formation and were divided into two general theoretical camps. Resource mobilization theorists focused on quantifying the human, social, and economic capital necessary for social movement success, and political process theorists examined the broader social contexts that allowed for movement formation, growth and development (Della Porta and Diani, 1999). Meanwhile, urban social movement theorists analyzed how contentious action impacted social relationships within cities and debated what potential these locally 
based mobilizations showed for creating larger transformative change (Castells, 1983; Pickvance, 2003).

This chapter reviews that brief literature that developed in the 1970s and 1980s around the concept of the urban social movement. That literature debated the definition, distinguishing characteristics, and influence of urban movements. The resulting knowledge about the defining characteristics and lasting impacts of grassroots, urban-based organizing is described, critiqued, and evaluated. The direction of recent debates about urban movements is examined in light of the original questions that urban researchers asked. The chapter concludes with a summary of the gaps that exist in this brief literature.

Urban social movement literature developed during the wave of urban uprisings that swept through the U.S. and Europe in the late 1960s and early 1970s. One of the earliest studies was Susan Fainstein and Norman Fainstein's (1974) Urban Political Movements, an account of minority neighborhood organizing in east coast cities. Fainstein and Fainstein shared the pluralist assumptions of their contemporaries in political science, and they argued that urban movements were the result of the lack of opportunities for mainstream political representation in these communities. They believed the demise of machine politics created a situation where political parties could write-off minority neighborhoods. Candidates no longer had to offer concessions to the poor in exchange for their votes, and therefore urban minorities became divorced from the political system. Fainstein and Fainstein's view of urban political movements corresponded with the classical sociological explanation for 
movement formation. In this view, collective action emerges in response to societal strain, and it weakens as marginalized groups are gradually incorporated into the political system (Tumer and Killian, 1987).

European sociologist, Manuel Castells (1977) offered an alternative description of urban social movements. Writing from a Marxist perspective, he viewed local movements as the neighborhood equivalents of trade unions. These movements were organized around the distribution of collective consumption resources in the city. Collective consumption resources referred to the public goods and services such as housing, land tenure and education that are provided by the local authorities. Castells' urban social movement was class-conflict waged in neighborhoods. Political scientist, Ira Katznelson (1981) also used a Marxist framework to examine neighborhood mobilizations in the Washington Heights area of New York, but he arrived at a different conclusion. Rather than sites of class-conflict that Castells had witnessed in Europe, Katznelson argued that neighborhood movements inhibited the development of a class-consciousness in the United States. Working-class New Yorkers remained divided by the "city trenches" of ethnic and racial politics, when they could have been uniting over class-based issues in their workplaces.

There is a long history of ethnic and racially based movements in the urban United States, while workers' organizations dominated in the cities of Europe. European social movement theorists conceptualized the city in terms of class-conflict (Edelman, 2001). When youth, citizens', women's, and environmental movements began to flourish during the late 1960 s and early 1970 s, European social movement 
theory underwent a radical transformation. Alain Touraine (1988) called these growing, non-class based conflicts "new social movements." Theorists believed that new social movements were a post-industrial phenomenon, and these movements were a response to the rapid capitalist encroachment of the everyday lives of urban dwellers (Melucci, 1989).

In the context of new social movement theory, Castells continued to work on questions regarding the urban social movement. After years of study and participation in movements on three different continents, Castells published his tour de force, The City and the Grassroots in 1983. The purpose of this book was to build a definitive theory that could classify the nature of urban social movements and qualify how they contribute to the construction of social relationships in the city (Castells, 1983). Castells distinguished the urban social movement from the conflict between capital and labor as well as from Touraine's new social movements. He defined the urban social movement as an "urban- oriented mobilization that influences structural and social change and transforms urban meaning" (Castells, 1983, 305). Using crosscultural case studies of urban movements throughout history, Castells identified three primary areas of urban social movement conflicts: collective consumption, political autonomy, and cultural identity. Movements that fought for collective consumption issues were neighborhood manifestations of the conflict between capital and labor. Movements that wanted political autonomy organized for decentralized decisionmaking. Identity movements sought cultural recognition and freedom from the forces of technocracy and assimilation. Castells argued that only when urban social 
movements incorporated all three of these demands, did they have a chance to successfully transform the city.

Urban social movement theory stalled quickly after the publication of The City and the Grassroots. A few theorists criticized Castells' methodologies and conclusions, but no one offered a viable alternative to his theory (Pickvance, 1976; Molotch, 1984; Lowe, 1986). Urban theorists, including Castells, soon switched their focus to global issues and relationships. The urban social movement was forgotten. A few social scientists recently began to pay attention to locally based organizing, by they are primarily concerned with the constraints and opportunities that globalization poses for urban movements (Mayer, 2000, 2003, 2006).

German political scientist, Margit Mayer (2006) recently assessed the theoretical contributions Castells made in The City and the Grassroots. While still agreeing with his basic classifications of urban social movement activity, Mayer viewed his work as a relic of the "historical moment of high Fordism" that is no longer relevant in a post-Fordist, or globalized, world (Mayer, 2006, 205). Her own studies of contemporary urban protest uncovered two new areas of concern for local activists. Conflicts are now currently waged between service recipients and their non-profit providers, and local organizations have begun to build connections with new transnational movements.

While Mayer elaborated on Castells' triad of urban social movement goals, she did not challenge his basic assumption that local movements could be differentiated from their larger-scale counterparts by their particular sets of demands. Collective 
consumption, political autonomy, and cultural recognition are not merely an artifact of an earlier era, they are also so broad that they could reasonably be applied to almost any social movement, regardless of its geographic scale. Instead of analyzing the particular demands of urban movements to discover what makes them unique, the distinct processes of local collective action needs to be considered.

Francis Fox Piven and Richard Cloward's (1979) Poor People's Movements outlined the distinctive mobilization processes that distinguish local movements from other scales of resistance. Although they did not label their movements "urban" mobilizations, the poor peoples' protests they studied all sought to make changes on cities in which they occurred. Piven and Cloward's research supported Castells' assertion that the urban-based social movement is a distinct phenomenon that opens up new arenas of conflict outside of the traditional struggles for redistribution or recognition. Rather than identifying urban or poor peoples' movements by their specific sets of demands, Piven and Cloward instead paid attention to the dynamics and characteristics unique to this type of mobilization. Poor people's protest actions were waged in their neighborhoods they lived in and targeted the institutions that directly impacted their lives. The unemployed leagues did not march on Washington to demand higher benefits; they shut down local relief offices. The anti-eviction movement did not lobby City Hall for a rent-freeze; they surrounded apartment buildings to prevent tenant's evictions. In Street Politics, a contemporary study of poor people's movements in Iran, similar characteristics of urban-based activism were identified (Bayat, 1997). Tehran's poor protested for the right set up stalls on the 
city's streets, to get tenure to squatted lands on the urban periphery, and to permanently occupy abandoned apartment buildings. In other words, the urban movements of the poor grew out of their everyday lives and sought to make changes that would immediately impact their daily routines, improve the quality of life in their neighborhoods, and expand their opportunities for survival.

Poor people's movements struggle within an extremely localized framework. Geographic scale is the defining feature of urban social movements as well. These movements can be distinguished from other scales of grassroots mobilizations by their concern for the local (Lake, 2006). Byron Miller (2006) argued that the spatiality of urban movements is what differentiates them from other scales of mobilization. Manuel Castells agreed: "Urban space is a fundamental component in the process of, formation of social movements as well as the expression of these movements that aims at the transformation of the urban environment" (Castells, 2006, 202).

The fact that urban movements seek grassroots changes on a local level led some theorists to downplay the potential these mobilizations have for creating transformative change. Geographer, Andy Merrifield celebrated the alternative urbanism that local social movements struggle for and create, but he still insisted that urban activists need to "learn to generalize as they particularize" in order to confront global economic forces (Merrifield, 2002, 172). Fellow geographer, David Harvey cautioned against the "militant particularisms" of movements that are "empowered in place but not across space" and therefore incapable of transforming contemporary urban communities which are increasingly held captive by the forces of global capital 
(Harvey, 1996, 168). Even Castells, who elevated the urban movement to a discrete category of resistance, ultimately saw the greatest potential of these movements in their ability to "nurture the embryos of tomorrow's social movements within local Utopias" (Castells, 1983, 313).

Rather than analyzing the impacts of urban social movements have on their local contexts, these scholars attempted to transcend geographical scales and focus on the potential that local movements have for creating fundamental national or international level changes. Fainstein and Fainstein (1974) measured the impacts that urban political movements had on participation in party politics. When no nationallevel impact could be found, they concluded that community organizing efforts created negligible changes outside of the neighborhoods they took place in. Fainstein and Fainstein never explored what the effects of those movements were within their neighborhoods or how the daily routines of people in those communities were transformed. In The City and the Grassroots, Castells (1983) measured the impacts that local movements had on a city's urban meaning, urban function, and urban form. Urban meaning referred to the role that cities play in a particular social system during a specific historical moment. A city's urban meaning encompasses its mode of production, form of political organization, relationship to other cities and territories, and its cultural significance. Urban meaning is historically produced, implying that it is born out of a conflictual process that is constantly renegotiated. For example, the urban function of a colonial city is to export the raw materials of its hinterlands to the colonizing nation and to facilitate direct rule. Urban meaning is manifested through a 
city's urban function, the social relationships and institutions that carry out its meaning. Urban form referred to the built environment that is representative of a city's urban meaning.

Castells (1983) used this typology of urban meaning, function, and form to evaluate the impacts his case study movements had on the city. Clearly, Castells was searching for movements that had the potential to transform urban meaning. He reserved the title "urban social movement" to describe only those conflicts that achieved such a transformation. Those that impacted urban form were dismissed as merely changing a city's design without affecting its function. Movements that challenged urban functions were viewed as reformist efforts. Of all of his case studies, only the Madrid Citizens' Movement accomplished a change in urban meaning by achieving a complete transformation of the politics, economics and culture of that city.

Castells was criticized for his methodological inconsistencies. Stuart Lowe (1986) took issue with Castells' choice of the Madrid Citizen's Movement as the benchmark by which all other mobilizations were judged. Lowe argued that the Madrid case was an historical anomaly, and it created a false measure of the impact and effects of community politics. Chris Pickvance (1976) critiqued Castells earlier work where he also relied upon the Madrid case. Pickvance believed Castells was too movement-centric, and he did not acknowledge role that local politics played in facilitating social change. Pickvance argued for an urban social movement theory that pays more attention to the unique political and historical contexts of its cases. 
Harvey Molotch (1984) was so dismayed by the complex coding schemes Castells used that he questioned the validity of urban social movements as an appropriate level of analysis.

While these critics addressed the methodological problems of Castells' work, no one questioned his assumption that the purpose of urban social movements is to create large-scale revolutionary change. By focusing on the three lofty demands of urban movements, Castells failed to recognize the true aims of these urban protests, which is to transform the immediate neighborhoods, routines, access to resources, and local status of city dwellers. Therefore, he could not evaluate their potential contributions. Piven and Cloward (1979) discovered that urban movements were successful because they were able to disrupt daily routines. Once these movements became institutionalized and organized into larger-scale efforts, they lost the ability to disrupt and spark immediate and direct changes in the lives of their participants. Although Piven and Cloward's arguments were written as a critique against the dominant assumptions of resource mobilization theory, their conclusions support the idea that when movements are particularized, their strength lies in the ability to create micro-level change. The effectiveness of local-scale movements needs to be measured in terms of the impacts it has on people's everyday lives. When Castells asked, how do urban social movements matter, what he really wanted to know was do they have the potential to create larger-scale revolutionary change?

This project tries to understand urban social movements on their own terms. The aim of this study is to discover the changes that urban movements can make on a 
localized level. Rather than evaluating the revolutionary potential of these movements, I revisit the questions that initially mattered to urban social movement researchers: What are urban movements and how do they make a difference? The brevity of urban social movement research never allowed for a full testing and evaluation of its key concepts and theories. This project will use an empirically grounded approach to explore the key concepts of urban social movement research. By looking at a decade of protest in the urban Pacific Northwest, questions about the definition, role and impact of local movements will be answered. The following chapter introduces the questions that framed this study and the methodologies that were used to answer them. 


\section{CHAPTER THREE \\ WHAT ARE URBAN MOVEMENTS AND HOW DO THEY MATTER? RESEARCH QUESTIONS AND METHODOLOGY}

This chapter outlines the main research questions, methodological approaches, and theoretical constructs that are used throughout this study. The purpose of this study is to return to that original problem that urban social movement theorists set out to resolve: What are urban movements and what impacts do they leave on the cities they take place in? Our knowledge of urban movements is based upon a brief twentyyear old debate that rarely approached these questions using a systematic and empirical method (Pickvance, 1976; Molotch, 1984; Lowe, 1986). In this project, the urban protests that occurred in Portland and Seattle during the 1990s are used as a foundation to explore the following questions:

- What urban movements occurred in the Pacific Northwest during the 1990s?

- What goals were these movements struggling for?

- What impacts did urban movements have on the daily lives of their communities of interest in Portland and Seattle?

This project builds upon earlier efforts to create a theory of urban movements by taking an empirically grounded approach to explore the role that urban movements play in constructing cities.

What urban movements occurred in the Pacific Northwest during the 1990s? Castells chose his case study movements from an array of resistance that took spanned centuries and took place on three different continents. The scope of this 
project is much smaller. Seattle and Portland are comparatively ordinary cities, although Seattle gained an international reputation for activism after the shutdown of the World Trade Organization meetings. During the 1990s, there was little debate about urban movements, and the protests that took place throughout this time frame did not elicit the same level of critical attention that the local movements in the 1960 s and 1970s did.

A protest event analysis was conducted to find out what urban movements took place in the Pacific Northwest from 1990 to 1999 . Protest event analysis is a catalogue of all protests that took place in a particular geographic area over a certain period of time. Event data is collected through newspaper reports. Protest event analysis was initially used by scholars who studied strikes, riots and political violence (Tilly, Tilly and Tilly, 1975; Tarrow, 1989). It was later adapted by researchers and applied to the study of the development of particular movements (McAdam, 1982). Protest event analysis is now widely used in social movement studies to analyze the interactions between movements, their setting and the political contexts that give rise to them (Koopmans and Rucht, 2002). Two large data sets of protest events are currently being collected in Europe and Canadian scholars are also using this technique to catalogue urban protests in Montreal (Koopmans and Rucht, 2002; Fontan et al., 2007).

Protest event data is collected from newspaper reports on demonstrations, rallies, strikes and other forms of collective action. Some historians also rely on court and police records or municipal notices to catalog protest (Clemens and Hughes, 
2002). Once protests are identified, researchers then code the data for specific variables of interest, such as size of the event, protesters' issues, tactics used and the police reaction to it. The advantages of conducting a protest event analysis are that researchers can detect movement patterns over a given time frame, link protests to their political contexts and identify the themes that are evident among a series of events. The disadvantages of this method are that it relies on mainstream newsprint sources which are often biased against grassroots movements, and it fails capture the organizational dynamics that contribute to a movements' formation (Rucht and Koopmans, 2002).

Protest is an indicator of social movement activity. By definition, social movements must engage in protest or some public performance of contention (Della Porta and Diani, 1999; Tilly, 2004). Nevertheless, not every protest is supported by a social movement. Some protests are organized to express public outrage over a specific event or political incident and never develop into a sustained campaign or organized network. While not every protest is a social movement, every movement engages in protest. In that respect, protests are a reliable gauge of social movement activity. Recording protest events is a useful method for identifying social movements. A cluster of events about a particular issue can indicate the presence of the larger campaigns and networks that define social movements.

The public performances of a movement are its most visible parts, yet before a protest can happen, a lot of organizing has to take place behind the scenes. Issues must be identified, organizations formed, meetings called and advertized. Goals, 
missions, strategies and tactics must all be agreed upon; then an event can be planned. Volunteers need to be motivated and organized, phone calls made, posters hung up, press releases written, speeches composed, banners painted and march routes plotted out. Newspaper articles leave out these invisible tasks that go into organizing a protest and instead feature sound bites from a particularly glib speaker or slogans from the most creative signs or banners. However, these signs, banners and sound bites are the way that social movements communicate their issues with the larger public.

Protest event analysis was criticized for its dependence upon mainstream newspaper reports of movement activity. Newspapers are thought to under-represent the level of protest and to overemphasize the importance of violent movements (McCarthy et al., 1996). Although these critiques are certainly well-founded, media coverage can also represent a baseline measurement of social movement success. In contemporary society, the mass media is one of the most effective means of communicating with a wider audience. For that reason, protesters are often fully aware of the impacts that a positive, or negative, media portrayal of an event has on a movement. When masked anarchists broke out corporate chain-store windows during the WTO protests, other activists tried to distance themselves from the negative publicity (Postman and Mapes, 1999). In this way, The Battle of Seattle was coconstructed by the protesters and the media. Protests that make the news already have entered the public's consciousness because of their size, visibility or the zealousness of their actions. Protest reporting also highlights actions that perceived to be "threatening" to the status quo (Clemens and Hughes, 2002). Even though 
newspapers don't capture every protest that occurs, they will report on those that have potential to make an impact on local politics or culture.

These critiques of media bias were taken into account in this project. To correct for these biases, data were collected from both mainstream and alternative sources. Portland event data were gathered from The Oregonian, a mainstream daily paper, The Skanner, an African-American community weekly, and The Alliance, an alternative news-monthly. Seattle event data were collected from the Seattle Times, one of two mainstream daily papers, and The Skanner, a local African-American weekly. These newspapers were chosen because they had consistent formats for indexing and access for the entire decade of interest. The keywords "protest and demonstrations" were used as a search term in each of the publications' databases. Event data were first collected from the mainstream papers and then supplemented by alternative coverage.

Protest events were recorded if they were collective not individual actions, extra-institutional yet not criminal in nature, and they took place within the boundaries of the city, not in its suburban or metropolitan area. Once the data were compiled, the protests were coded for the following variables: protest topic, protesters' political orientation, number of participants, protest target, police presence, tactics used and the protesters' goals. The protests were also analyzed to determine if they merely took place in the city or if they meant to produce changes on the city (Fontan et al., 2007). In order to be considered an urban social movement, a protest needed to be sparked by a local event, organized by a city-based group or targeted towards an urban institution 
(Nicholls and Beaumont, 2004). Appendix I lists all of the urban protests that took place in Portland and Seattle during the 1990s.

\section{What goals did urban social movements struggle for in Portland and Seattle?}

Narrative analysis was used to answer this question about the goals that urban movements struggled for in the 1990s. The purpose of this question is to understand what local activists were trying to achieve in the Pacific Northwest and to test the relevance of existing urban movement theory on this more contemporary case. A narrative approach was adopted when the coded answers from the protest event analysis did not provide sufficient data to delve into this question. The newspaper articles provided an additional, rich source of qualitative data that could be used to answer this question. The newspaper reports contained narratives of each particular event that could be analyzed for further meaning. Protesters' narratives were contained in their direct quotes, statements from press releases, slogans on signs and banners, protest chants and protesters' actions. All of these narrative data were collected and recorded for those events that occurred "on the city," or those which were considered urban social movements (Fontan et al., 2007). These data were analyzed to determine how applicable Castells' (1983) theory was to this particular case. When Castells' theory did not fully encapsulate the experience of Pacific Northwest urban movements, a new explanation was developed based on the protesters' narratives of these events.

Narrative analysis is an emerging tool in social movement research. Narrative analysis was first used by researchers interested in the relationship between social 
movement participation and the formation of collective identities (Polletta, 1998a). The use of narrative analysis was later expanded into other areas of social movement research. Narratives have been used to answer questions about how movements form, what activists do in times of repression and how politicians are influenced by protest (Polletta, 1998b). The stories that protesters tell can also reveal the meanings that social movement activism has for its participants (Davis, 2002; Auyero, 2003b).

In this project, the narrative data were used to uncover the goals that urban protesters were struggling for. It was important to try and get a movement-centric perspective of these protests. While acknowledging that the media co-constructs protest events, limiting the data to protesters' direct quotes and statements offered a relatively first-person account of these events.

According to Manuel Castells (1983), urban protesters fight for three defining goals: collective consumption, political autonomy and cultural identity. Protesters' narratives were coded using these three variables. Many events fit into more than one of Castells' categories. This was not incompatible with his theory, which states that in order to be successful, urban movements must combine all three demands. However, a few of the events in Portland and Seattle did not match any of Castells' goals. Urban labor movements, some neighborhood protests and exclusionary movements did not struggle for collective consumption resources, political decentralization or cultural autonomy. These movements fought: for better wages and working conditions, against drugs and crime in their communities, for the exclusion of groups from the city and for the defense of a community against exclusionary movements. 
When Castells' (1983) theory could not explain all of the goals that protesters fought for in the Pacific Northwest during the 1990s, a new classification of urban movement activity was developed. I created a coding schema that fit the patterns evident within the protesters' narratives. I discovered that protesters fought over five different aspects of the urban experience: labor, collective consumption, neighborhood, urban space and imagination. These five areas reflected the range of everyday uses of the city. The city is a place of employment, a home, a place to access public institutions and services, a built environment and a space of identity and belonging. The five categories revealed that urban protesters had diverse goals that grew out of their everyday life experiences in the city.

Everyday life is a philosophical notion that was originally developed to separate the mundane aspects of life from higher-order artistic pursuits (Sheringham, 2006). This concept was appropriated and more fully explored through a Marxist lens by the French philosopher Henri Lefebvre (2005a; 2005b; 2005c). Lefebvre conceptualized everyday life as both the product and residue of the capitalist system (Roberts, 2006). He believed the everyday was not separate from artistic pursuits, but the foundation for all higher-order thinking. Lefebvre viewed everyday life as simultaneously the sphere of alienation and appropriation. Once the everyday was exposed as such, it was instantly transformed to something beyond day-to-day existence.

This project uses a Lefebvrian interpretation of everyday life (Lefebvre, 2005a; $2005 \mathrm{~b} ; 2005 \mathrm{c})$. In this study, the concept of everyday life is used to capture the daily 
patterns, routines, paths and interactions that city dwellers and urban communities engage in. These are the taken-for-granted habits and activities that occupy our time. The everyday encompasses all of the structures, spaces and social relationships that facilitate our daily routines, constrict our opportunities and determine our quality of life. Urban movements disrupt everyday life by presenting alternatives to automatic daily routines and proposing new patterns of living and interacting. What impacts did urban movements leave on the daily lives of their communities of interest?

Urban movement theory first argued for a separate consideration of locallybased activism from national and international scale movements. The second issue that urban movement theory tried to address was the question of impacts. It is important to understand how urban movements impact the cities they take place in, so the role that movements play in constructing urban relationships, cultures, and institutions can be better understood. Urban movement theorists concentrated on examining the potential that local organizing had for making changes beyond the city; and in the process, they ignored the impacts these movements produced within it (Fainstein and Fainstein, 1974; Castells, 1983).

This question was designed to address how urban movements make changes within cities. Cities are not homogenous entities; they are dense, interconnected webs of social relationships. Social movements struggle to transform life for more than just those who participate in them; every movement defines a specific constituency that it is fighting for (Olsen, 1963). This constituency, or community of interest, was the 
level of analysis that was used to explore the question of urban movement impacts (DeFillipis and North, 2004).

While protesters' narratives were useful for uncovering the goals and meanings of each event from a participants' point of view, multiple perspectives and longerrange narratives were needed to determine how urban movements transform the lives of people in their communities of interest, so a case study approach was chosen. Case studies are commonly used in social movement research (Snow and Trom, 2002). Case study research was the primary method used to develop urban social movement theory (Fainstein and Fainstein, 1974; Castells, 1983; Lowe, 1986; Merrifield, 2002). The case study is so frequently used in social movement analysis, because it has the capacity to capture social processes (Stoecker, 1991). A case study is chosen when researchers want to address questions that ask how or why (Yin, 1984). Case study research allows for high-quality and in-depth observation about social process that may not be visible in broader-based survey and experimental designs (Flyvbjerg, 2006). Understanding how movements impact cities is a question of social process that requires the longitude and breadth that case study research offers.

Five mini-case studies were conducted to answer the question about urban movement impacts. It was not necessary to conduct exhaustive research into each of these cases, because the purpose of the research was to identify commonalities and trends across these cases. Five movements were chosen; one to represent each of the five areas of everyday life that protesters contested in Portland and Seattle during the 1990s. These cases were chosen from the wider protest event analysis. Each case 
needed to meet specific criteria to ensure that it was not just a single protest event, but a social movement. In order to be considered, a case needed to consist of multiple events, over an extended time period. These criteria ensured that the protests fit Tilly's definition of a social movement, a sustained campaign that engages in protest to demonstrate worthiness, unity, numbers and commitment to a particular cause (Tilly, 2004, 3). An effort was made to distribute the cases evenly between the two cities. In the end, three cases from Portland (The Hotel Workers' Organizing Committee, The Black United Front's school boycotts and the Rose Festival princess pageant protests) were chosen and two were selected from Seattle (the coalition against the Weed and Seed policing program and Operation Homestead's occupations of downtown buildings).

The cases were analyzed to determine how these movements transformed the daily lives of their communities of interest. Since everyday life is all of our taken-forgranted habits and routines, it had to be operationalized into smaller, discrete categories in order to evaluate the process of its transformation. The philosophical writings of Henri Lefebvre (2005a; 2005b; 2005c) were used as a basis for choosing the aspects of everyday life that would be examined in this project. To Lefebvre $(1991 ; 2005 \mathrm{a} ; 2005 \mathrm{~b} ; 2005 \mathrm{c})$, time, space, and social relationships were the principal forces that shape daily life. In addition to these three categories, sense of possibility was also considered. Movements transform daily life by exposing automatic routines as mutable. For this reason, the sense of possibility that movements provide to their constituencies was considered an important factor. These four aspects of daily life-- 
time, space, social relationships and sense of possibility-were furthered operationalized into the following research questions:

1. Time: How did these movements change the daily routines of their community members?

2. Space: Did these movements construct new spaces in the city or transform the way the built environment was used?

3. Social Relations: Did these movements create a new community, new identity or change the ways in which people within a community related to one another?

4. Sense of Possibility: What new ideas did these movements present about city policy, social relationships and the responsibility for urban problems and solutions?

These questions guided the data collection and analysis for the five mini-case study movements.

Data were collected from municipal and institutional archives and newspaper reports. The Stanley Parr Archives and Records Center in Portland contained movement and public documents for the Hotel Workers' Organizing Committee and the Black United Front. The archives at Portland Public Schools had a record of all media reports on the school boycotts as well as a record of discussions that took place in school board and committee meetings. The Seattle Municipal Archives contained movement and public documents about the Weed and Seed opposition and Operation Homestead. The journalism department at Portland's Cleveland High School had 
back issues of the school newspaper that reported on the Rose Festival pageant protests.

The archival documents and newspaper accounts provided a timeline of movement activity and a record of the policy impacts that these actions had on the city. However, these data did not fully address the question of the transformations that these urban movements made in the daily lives of their constituents. In addition to archival data, interviews were also conducted. At least one protest organizer from each movement was interviewed either by phone or in-person. In most of the cases, just one organizer was interviewed because it was difficult to track down protest organizers from the 1990s. Those who were interviewed were organizers who remained in town and remained active in their communities. Protest organizers were chosen instead of participants, because the organizers were more likely to be aware of the entire range of community experiences. In addition to this movement-wide perspective, organizers had historical knowledge of their movement's development.

In conclusion, this study returns to the questions that were at the forefront of the urban social movement debate: What are urban movements and how do they matter? It addresses the methodological issues that plagued earlier urban movement research by using an empirically grounded approach. The protest event analysis coded and narrative data provided a foundation for exploring the questions about movement definitions and goals. A portrait of urban social movements as transformative actors in the sphere of everyday city life emerged from this data set. The mini-case studies built upon these connections between urban movements and everyday life. The case 
study research evaluated the successes these movements had in transforming the use of time, construction of space, development of social relationships and sense of possibility within their communities of interest.

The following chapter addresses the question: What urban social movements occurred in Portland and Seattle during the 1990s? It explores the context of protest in each city and describes the urban movements that took place throughout the decade. The next chapter examines the question of movement goals and further develops the notion of movements as a transformative actor on everyday urban life. The second part of the dissertation is devoted to the question of movement impacts. 


\section{CHAPTER FOUR \\ URBAN SOCIAL MOVEMENTS IN A GLOBAL AND REGIONAL CITY: A DECADE OF LOCAL PROTEST IN THE PACIFIC NORTHWEST 1990-1999}

In the early 1990s, the state Republican Party chairman told the Oregonian newspaper that White House officials "jokingly refer to Portland as the Beirut of the United States" (Mapes, 1991, A1). Portland earned the nickname "Little Beirut" after a series of violent demonstrations greeted presidential and vice presidential visits to the city. Ten years after the smoke cleared from the streets of downtown Portland, rowdy demonstrations in the Pacific Northwest again drew national attention when fifty thousand people marched in the streets, blockaded intersections, barricaded doors and broke windows, effectively shutting down of the World Trade Organization meetings in Seattle. Yet these popular outbursts were just a handful of the over six hundred protests that took place in Portland and Seattle during the 1990s. Table 4-1 shows the distribution of protest between the two cities. Demonstrations were often more routine than the Little Beirut and WTO events, but urban residents in the Pacific Northwest frequently used protest to express their political views.

Table 4-1 Protest in the Pacific Northwest 1990-1999

\begin{tabular}{l|l|l} 
& Number of Events & Percentage of Events \\
\hline Seattle & 354 & $51.45 \%$ \\
\hline Portland & 334 & $48.55 \%$ \\
\hline Total & 688 & $100 \%$
\end{tabular}

Protesters in the urban Pacific Northwest joined together to effect economic, social and cultural changes on the international, national and local levels. Peace and justice issues made up a large segment of protest activity. Peace and justice issues are 
frequently associated with protest; however, residents concerned with education, housing, neighborhood conditions, and police conduct also used rallies, marches and civil disobedience to make their voices heard.

This chapter introduces the two case study cities and examines the urban social movements that occurred in each. The first section explores the different protest environments in Portland and Seattle and describes the types of protest, their political contexts, and the police responses that emerged in each place during the 1990s. The next section defines urban social movements and presents the results from the protest event analysis catalogue of "on the city" movements in the Pacific Northwest (Fontan et al., 2007). The development of the housing movement in Seattle, which was the primary issue that grassroots activists organized around during the 1990s, is discussed. In Portland, urban activism was dominated by racial politics, and race relations in the city of Portland are further explored.

\section{Seattle: Protest in a "Pacific City"}

According to Carl Abbott, Seattle is a "Pacific City" oriented towards its role in a global Pacific Rim economy, while Portland is remains a "Northwest City" acting as a regional urban hub for the Columbia River Basin (Abbott, 1992, 317). During the 1990s, Seattle aggressively marketed itself as the prototypical information age city (Lyons, 2004). Boasting the headquarters of Microsoft, a bustling trade with Asia, and a new pop music sound known as grunge rock, Seattle self-consciously styled itself as the archetypical, globalized city. The city bolstered its growing reputation with an assertive campaign to attract multiple large-scale national and international events. In 
1990, Seattle hosted the Goodwill Games, a sporting event designed to foster harmony between eastern and western- bloc nations. In 1993, the city sponsored a NAFTA conference and welcomed the APEC (Asian Pacific Economic Conference) summit. In 1994, various heads of state visited for a NAFTA trade exhibition. In 1995, the city held the Final Four college basketball tournament for the third time in a decade and sports boosters were gearing up to make a bid on the 2008 Olympics. Finally in 1999 , the infamous World Trade Organization meetings took place in the city.

Each of these large-scale events drew protestors. During the APEC conference, Tibetan monks, AIDS activists, and displaced homeless residents all organized protests ("Schedule of APEC Events," 1993). The Goodwill Games drew activists concerned about Central America as well as those opposed to the violence in boxing (King, 1990). These events provided a global stage for the East Timor Action Network, U.N. Membership for Taiwan, and forest and fisheries activists to catch the attention of the international press and power brokers.

Even when no large-scale events were in town, Seattle remained a hub for peace and justice organizing. In 1990, one-third of protests challenged U.S. militarism and foreign policy. In January, over sixty demonstrators opposing U.S. aid to El Salvador were arrested at the federal building (Angelos and Broom, 1990). In June, a Soweto Day march and rally called for local divestment from the apartheid government of South Africa (Mann, 1990). In August, when the Navy docked in Seattle's port for the annual Sea-Fair event, they were greeted by anti-nuclear protesters (Angelos, 1990a). In the fall of 1990, peace and justice activists concerned 
with many different issues began to come together to protest the U.S. military build-up in the Persian Gulf. These anti-war marches were considerably larger than previous events, drawing thousands of demostrators. By the time the U.S. invaded Kuwait, Seattle peace and justice activists had temporarily put aside their individual political issues to work in coalition against the war.

In 1991, peace and justice concerns dominated the protest landscape in Seattle. Half of the events recorded for that year were peace protests, and $88 \%$ of those were actions against the Persian Gulf War. While the peace movement grew in size in 1991, the overall number of protest events actually declined. Instead of multiple activists from various groups organizing events, the war brought disparate organizations and issues together to support fewer, yet larger-sized, anti-war protests. The quick resolution of the conflict in the Persian Gulf was reflected in the decline of peace and justice organizing. By 1992 , peace marches accounted for only $5 \%$ of protest events that year.

Seattle's peace and justice protesters were disproportionately likely to draw a police response. Activists were arrested at thirty-two percent of all peace and justice protests during the 1990s. The rowdy demonstrations that took place during the World Trade Organization meetings inflate this percentage, but Central American, anti-nuclear and anti-apartheid protesters in the early 1990s frequently engaged in civil disobedience. The police facilitated activists' desires to challenge U.S. foreign policy through symbolic and direct actions by arresting protesters without incident and releasing them with only a citation. Protesters did their part by self-policing the 
actions of the crowd. When demonstrators broke out the windows of the federal building at the start of the Gulf War, protestors who were occupying the plaza collected money to repair them (Guillen, Broom, Norton and Henderson, 1991). Later during the WTO protests, some activists repaired Starbucks' windows that more radical protesters had broken out (Postman et al., 1999).

This collaboration between police and activists in Seattle helped facilitate the city's global ambitions. A tolerant, yet effective, police response to protest ensured the security of global leaders without compromising the civil liberties of protesters who played by the rules. Protest garners media attention, which adds to the global reputation of the city. While protest may not always generate a positive media image, getting any press is better than no press at all. Tolerance of protest also helps a city sell itself as a cosmopolitan metropolis, sophisticated enough to deal with a diversity of opinions and actors.

The Seattle Police Department's tolerance of protest was as much a product of public pressure as it was city policy. The public desired a tolerant police response to protest and were willing to take to the streets when they felt the police were out of line. In 1992, community activists protested the felony charges levied against Rodney King rioters. The activists argued that the rioters should be charged with misdemeanors because "they will learn a lot more from community service than from jail....We cannot allow what they did to happen but this is not LA" (Norton and Birkland, 1992, B2). 
When anti-racist and homeless youth rioted in the Capitol Hill neighborhood, activists protested the police handling of the incident (Haines, 1994a). In 1997, the bike advocacy group Critical Mass demonstrated against the police conduct at a weekly ride, but they were careful to reassure the city: "We wish no confrontation with the police" (Broom and Bymes, 1997, B1). Critical Mass even encouraged the iconic Seattle bicycle officers to join them on future rides. When the World Trade Organization riots hit Capitol Hill, neighborhood residents were tear-gassed and beaten by Seattle police, and they promptly protested this treatment. Within days, the city set up a committee to investigate the incident (Ith and Burkitt, 1999).

Although Seattle's status as a "Pacific City" generated large numbers of internationally focused protests like those against the WTO, it also fueled local conflicts. David Harvey (2001) writes that capital constantly searches for a new "spatial fix." In the 1990s, international capital found its fix in the real estate markets of cities like Tokyo, New York and Seattle (Sassen, 1991). High-tech companies bought up downtown office spaces, and six-figure salary employees drove-up rents and real estate taxes (Moody, 2004). Meanwhile, the city funneled major subsidies into mega-projects, like a new sports arena and an expansion of the convention center to compete for international capital and investment (Olds, 2001). This growing valorization of urban real estate sparked intense conflicts. Housing protests were the third most frequent category of protest in Seattle, accounting for $13 \%$ of all demonstrations. In contrast, housing actions made up only $4 \%$ of Portland's protests. Housing protesters decried the effects of the hyper-valorization of real estate by 
contesting rent increases, displacement, homelessness, and the destruction of lowincome housing. The burgeoning real estate market not only impacted the cost and availability of housing, it also fostered an atmosphere where low-income renters and homeless people were no longer welcome in downtown neighborhoods. In 1990, housing activists protested the demolition of a single room occupancy hotel located across from the Convention Center noting: "It's a sad day when a building is torn down for no reason except that conventioneers don't want to walk past a class of people other than their own" (Plank, 1990a, B1).

In 1993, conflicts over housing intensified after City Attorney Mark Sidran proposed an ordinance to criminalize homelessness by banning sitting on downtown sidewalks, public urination, and panhandling. Homeless people, their housed supporters, and civil libertarians launched a spirited protest campaign and eventually filed a legal challenge to the Sidran laws. Protests died out after the courts upheld the law, and it went into effect in the summer of 1994 (Jung, 1994). Sporadic demonstrations continued that year, but homeless activists focused their priorities elsewhere, as the remaining court challenges snaked their way through the appeals system.

The Seattle Police Department's overall tolerance of protest did not always extend to low-income and non-white activists. Civil disobedience tactics were used by a great variety of movements, but the police response to these tactics was not always as conciliatory as it was with the primarily white middle-class peace and justice movement. Homeless and other low-income protesters who engaged in civil 
disobedience often did not negotiate with the police prior to their actions and were more likely to be victims of excessive force or to be arrested without adequate warning. In 1992, during the Rodney King protests, some participants were beaten by the police (Norton and Birkland, 1992). The first night of protest and rioting, the Seattle police attempted to use their customary, appeasing style of policing. Twentyfive people were arrested (Gupta et al., 1992). The second night of unrest prompted a larger police presence and resulted in one hundred and twenty-five arrests. As if making up for the hands-off stance of the night before, police indiscriminately arrested people on the streets. One activist who participated in a peaceful protest march commented: "I feel confused and frustrated and just disbelieving. I don't know what we've done that was so unlawful. We came out and wanted to demonstrate peacefully, and it seemed peaceful but the police cut us off at every opportunity" (Angelos et al., 1992).

\section{Portland: Protest in a "Regional City"}

In contrast to Seattle's globally driven protest scene, Portland activists confronted Pacific Northwest regional issues. In the 1990s, the Pacific Northwest was in the midst of a war over the use of the region's most valuable resource-forests (Durbin, 1996). This war pitted environmentalists against loggers and urban interests against rural. Portland hosted two major events during the decade, both focused on the fate of Northwest forests. The 1992 "God Squad" hearings listed the spotted owl as an endangered species, curtailing the logging in old growth forests (House, 1992). In 1995, the Northwest Forest Conference produced a compromise federal forest 
policy that temporarily ended the timber wars between environmentalists and logging companies (Durbin, 1996). Both of these events attracted protesters, from log-truck brigades to local Earth Firsters dressed as Smokey the Bear (Laatz, 1995). Unlike the globally-oriented events in Seattle, Portland hosted conferences to discuss and solve regional issues.

Until the 1980s, the Pacific Northwest regional economy was dominated by the timber industry. When the timber industry collapsed, the region entered into a prolonged period of economic and social turmoil. While struggling to redefine its niche in the global economy, the Pacific Northwest also grappled with its cultural identity. Conflicts between environmentalists and loggers were just one battle in this new cultural divide. The Oregon Citizens' Alliance (OCA) campaigned against gays and lesbians, and anti-abortion groups targeted feminists. Neo-Nazis attacked anyone who wasn't straight, white and of Nordic heritage. These battles between the right and left dominated politics in Portland in the early 1990s, mirroring the wider regional turmoil that was taking place in the vacuum left by the demise of timber industry.

During the 1980s and 1990s, Portland was a center for far-right and white supremacist organizing. In 1988, after a series of escalating anti-gay and racist attacks, neo-Nazi skinheads murdered a young Ethiopian immigrant named Mulugeta Seraw (Langer, 2003). This crime captured the public's attention and generated a wide array of political responses, from peaceful rallies and marches to outright brawls between young anti-racists and skinheads. Groups like Anti-Racist Action occasionally resorted to violence to drive skinheads out the community. One young 
member declared: "We have to expose them and the chance of violence we feel is a risk we need to take" (Rollins, 1990, C5). While the fight against skinheads was being literally slugged out in the streets of Portland, national anti-racist organizations joined into the fray. In 1991, the Southern Poverty Law Center filed a civil suit against California white supremacist Tom Metzger, charging him with wrongful death liability in the Mulugeta Seraw case. The Portland skinheads that murdered Seraw were members of Metzger's White Aryan Resistance organization.

In addition to the skinhead movement, Portland was home to other right-wing campaigns. While the neo-Nazis used violence to achieve their goals, the antiabortion movement used protest. Portland's three women's health clinics were constant targets of pickets, blockades, and acts of vandalism. In 1989, clinic defenders spent eight hours trapped inside the Feminist Women's Health Center after antiabortion protestors had surrounded the building (Boule, 1989). By 1990, local clinics won civil injunctions against anti-abortion protestors, requiring the police to enforce a boundary around health care centers. In 1990, eight anti-abortion protestors spent months in jail for refusing to abide by the conditions of the injunction. The refusal of the so-called "Lovejoy Eight" to agree to follow the rules of the injunction catalyzed Portland's anti-abortion movement (Leeson, 1990, D1).

While violence and protest brought media attention to right-wing causes, their strongest victories were won through the ballot box. In 1988, the Oregon Citizens' Alliance (OCA) passed Measure 8 which reversed a state order banning discrimination against gays and lesbians. In response to the passage of Measure 8, gay and lesbian 
activists blocked traffic on Portland bridges, the first in a series of more militant protests (Blackmaun, 1988). Activists from the gay and lesbian rights movement, clinic defenders, and anti-racist youth eventually organized the protests against Bush and Quayle that earned the city the nickname "Little Beirut" (Mapes, 1990, A1).

By 1992, the political landscape in Portland had shifted. The Southern Poverty Law Center won their suit against Tom Metzger and skinhead attacks lessened. The Lovejoy Clinic prevailed in their case against the eight anti-abortion protesters. Only the OCA remained unscathed and on the offensive. In 1992, they sponsored Measure 9, a new anti-gay statewide initiative. The gay and lesbian rights movement was forced on the defensive and went from organizing protests in support of amnesty for gay and lesbian immigrants to fundraising for a media campaign to defeat the measure. The need to defeat Measure 9 became even more pressing after the OCA successfully passed a similar measure in Springfield, Oregon, less than six months before the statewide election (Brown, 1992). The intensity of the divide over Measure 9 forced activists to abandon their protest tactics in favor of running a more traditional political campaign that could appeal to large numbers of voters. This shift to an electoral focus contributed to a steep decline in protest activity in 1992. After Measure 9 was defeated in November, the right-wing began to retreat. The electoral victory against Measure 9 signified the demise of the right-wing in Oregon. With the successful defeat of the skinheads, anti-abortion protesters, and the OCA, left-wing activists no longer had to protest to defend their ideal of a progressive Portland. 
A more aggressive and intolerant policing strategy emerged in Portland in response to these battles between right and left. While the majority of arrestees in Seattle were peace and justice activists engaged in civil-disobedience, the Portland police were often called in to separate two adversarial movements. When neo-Nazi skinheads held a "White Workers' Day" rally, the police stood as a physical barrier between the skinheads and a much larger anti-racist crowd (Rollins, 1991, D1). The police were also called in to remove anti-abortion protesters who blockaded access to clinics, harassed patients, and engaged in property destruction. Oregon's anti-abortion movement was one of the most radical in the nation. When extremists began murdering doctors in the mid-1990s, Portland based Advocates for Life issued a statement of support and published a pamphlet called A Time to Kill, in spite of the fact that every other anti-abortion group in the nation distanced themselves from these crimes (Bates, 1994).

The police were initially reluctant to confront militant right-wing activists. Prior to the murder of Mulugeta Seraw, the police ignored skinheads who were engaging in escalating attacks against black and gay Portlanders (Lagner, 2003). The police also refused to clear anti-abortion protesters away from women's clinics until health care workers got a court injunction compelling them to do so (Laatz, 1989). In the absence of a strong police response, gay and lesbian activists, clinic defenders and anti-racist youth began organizing grassroots defense movements to confront the growing strength of right-wing campaigns in Portland. 
Unlike their Seattle counterparts, police in Portland were often hostile to protesters and frequently behaved as if demonstrators posed a threat to the city. In 1991, during a "Little Beirut" demonstration, one activist complained the police "charged the crowds" and "grabbed people by the hair" (Manzano 1990, B8). A few days later, demonstrators held a press conference to complain about the violent police response. Mayor Bud Clark issued a statement chastising both the police and demonstrators, claiming the police "were provoking the crowd as much as the crowd was provoking them" (Manzano, 1990, B8). Stan Peters, the president of the Portland police union called Mayor Clark "incredibly stupid" and reminded the public that the demonstrators were just "scum, knee-jerk liberals" (Ames, 1990b, B4). Peters claimed: "The people on the streets of that demonstration are not our citizens of this city. They are street scum, and they become part of that scum when they use an incident like this to attack the police" (Ames, 1990b, B4).

The differences between demonstration policing and the character of protests in each city reflect the wider gulf between the distinct roles that Portland and Seattle chose to play in their region, nation and the world. Seattle's urban meaning was to be a significant node in the wider Pacific Rim economic network, while Portland remained a regional capital for its changing hinterlands (Castells, 1983; Abbott, 1992). These two divergent roles shaped the conflicts that occurred in each place and constrained protesters' opportunities for influencing international, national, and local change. 


\section{Urban Social Movements in the Pacific Northwest 1990-1999}

In 1994, on a rainy afternoon in downtown Portland, more than 3,000 environmental protesters sang along with a student choir to call for protection of the Opal Creek wilderness area ("Opal Creek Demonstration," 1994). Earlier that year, activists had gathered in a sunnier central downtown Pioneer Courthouse Square to demand an end to the U.S. embargo against Cuba (Darienzo, 1994). The previous spring, a vigil for murdered indigenous rights activist Anna Mae Aquash was held in front of the Bureau of Indian Affairs building (Lockhart, 1994). Though the Opal Creek wilderness area lies one hundred miles southeast of the city, and Anna Mae Aquash lived and died on the Pine Ridge reservation in South Dakota, activists still saw Portland as a viable soapbox for getting their protest messages out. Cities, regardless of their size or status, are often sites of protest aimed at larger scale decision-makers. Cities function as nodes in national and international power networks providing protesters with connections to higher-level leaders. Even if the pleas to end the embargo against Cuba never reached the Senate Foreign Affairs Committee, both senators from Oregon maintained staffed offices in downtown Portland. Cities are also home to symbolic outposts of power. Although the local Bureau of Indian Affairs office had no jurisdiction over the Pine Ridge reservation, it was representative of the institution that did. Even when the real or symbolic representations of decision-making power are not present, the city can still be an ideal setting for protest. Through its role as a communication hub, the city offers protesters access to wider audiences. The rainy environmental rally could have been held on the 
banks of Opal Creek, but television cameras and choirs of singing children would not have likely attended.

Cities are not only sites of protest aimed at higher-scale decision-makers, some movements want to make political changes on the urban level. In 1990, numerous protests for, and against, U.S. military intervention in the Persian Gulf took place the Seattle Federal Building, but protesters also had other grievances (Gough, 1990b). Public housing tenants staged sit-ins at the Seattle Housing Authority to challenge their high heating costs ("Once-Chilly Tenants," 1990). Union electricians disrupted the opening ceremonies of the downtown bus tunnel to demand that the city pay a prevailing wage ("Making a Scene," 1990). While the protests at the Federal Building happened to take place "in the city," the actions of public housing tenants and underpaid electricians occurred "on the city" (Fontan et al., 2007). Protests that happen "on the city" are urban social movements. For a protest to be considered part of an urban social movement it must be sparked by a local event, organized by a locally based group, and/or targeted at local power holders (Nicholls and Beaumont, 2004).

Public housing protesters and anti-war activists both linked their arms and refused to leave the buildings they occupied. Although the tactics and organization of urban and larger-scale protests may look the same, there is a marked difference in the relationship these movements have to the city. When a protest is held "in the city" but aimed at making larger-scale changes, its locale is an important resource. Metropolitan areas provide large population bases that movements can draw on, offer 
closer access to real or symbolic representations of power and ensure the broadcast of activists' messages out to a wider audience, through the proximity to urban media outlets. For urban protests, the city is more than just a locale; these movements attempt to actively transform and construct their location. In these cases, locality is not merely a setting; it is both the boundary and producer of the social relationships that "on the city" movements want to transform. Locality is "a social construction...the creation of social, political, and economic (inter)actions rather than a backdrop for such behavior" (Kirby, 1993). These are the conflicts that produce, challenge and reconstitute particular local institutions and relationships.

Urban social movements accounted for almost half of all protest activity in Portland and Seattle during the 1990s. ${ }^{1}$ Table 4-2 shows the frequency of urban Table 4-2 Urban Protests in the Pacific Northwest 1990-1999

\begin{tabular}{l|c|c|c} 
& $\begin{array}{l}\text { Protest Events } \\
(1990-1999)\end{array}$ & $\begin{array}{l}\text { Urban Protest Events } \\
(1990-1999)\end{array}$ & $\begin{array}{l}\text { Urban Protests Events as } \\
\text { Percentage of Total }\end{array}$ \\
\hline Portland & 334 & 154 & $46.11 \%$ \\
\hline Seattle & 354 & 149 & $42.09 \%$ \\
\hline Total & 688 & 303 & $44.04 \%$
\end{tabular}

protest in each city. From the Seattle Musicians' Union's pickets of the Beauty and the Beast musical to the marches and rallies against youth curfew laws in Portland, urban protests confronted multiple issues and were organizedby diverse communities (Benson, 1997; Gaynair, 1999). Figure 4-1 shows the top seven categories of protest in the two cities. In Seattle, housing was the primary issue that urban protesters

\footnotetext{
'See Appendix for a listing of all of the urban movements that took place in Portland and Seattle during the 1990s
} 
contested. Housing actions made up $23 \%$ of all urban protests in that city. In Portland, neighborhood, race and labor issues were equally as important, but no one category of protest dominated. The women's movement was stronger in Portland,

Figure 4-1 Categories of Urban Protest: Portland and Seattle 1990-1999

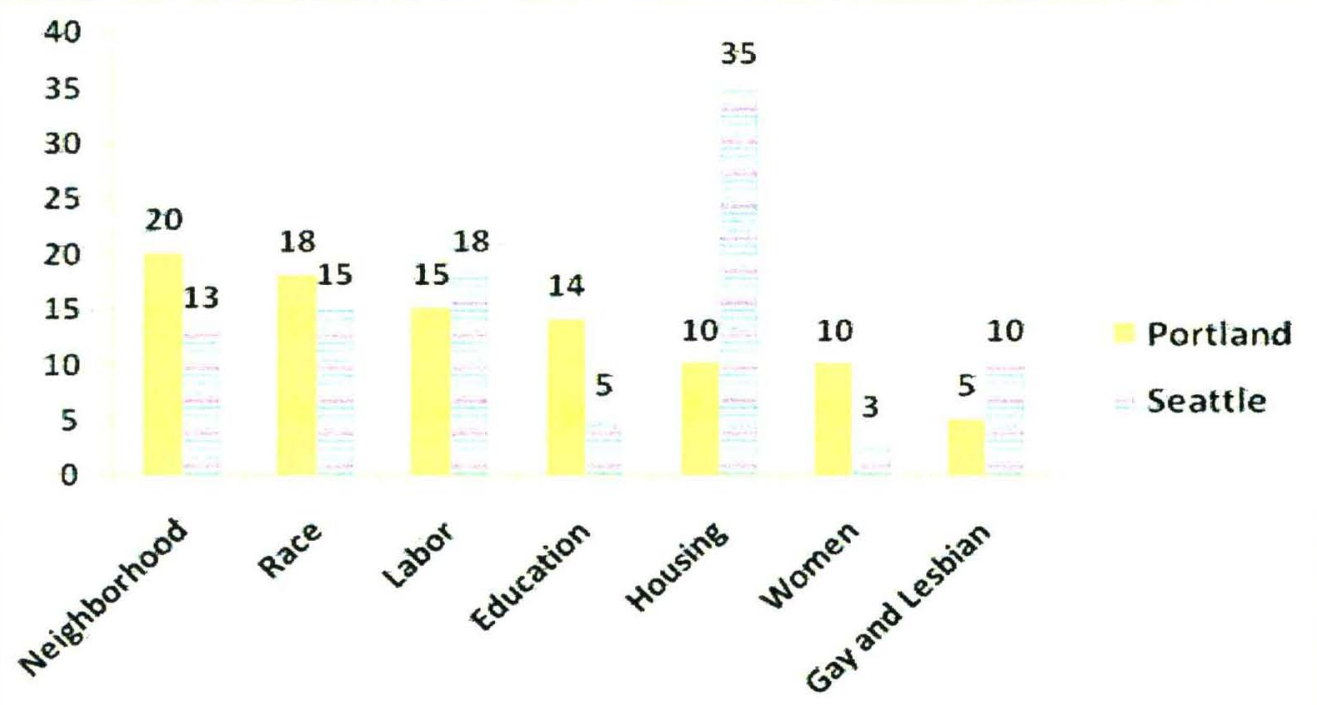

while Seattle was home to a larger and more active gay and lesbian community.

\section{Housing: A Grave Concern in Seattle}

Housing protests account for one-quarter of Seattle's urban social movement activity. Seattle's global orientation created a central city real estate market that catered to international capital and investment. As a result, low-income residents experienced rising costs, displacement, and the destruction of affordable housing options. Guido Martinotti (1999) observed that contemporary cities are primarily designed to meet the needs of temporary users, like tourists and commuters, instead of their permanent residents. Local governments raise revenue from suburban workers, local and foreign visitors and business tourists as valuable commodities. Hence, urban 
spaces and policies are designed for these temporary users while the needs of many long-term city dwellers are neglected. As the 1990s wore on, Seattle became increasingly oriented towards serving the needs of the global tourist and business class (Gibson, 2007). Early in the 1990s, low-income housing located next to tourist facilities was slated for demolition, and homeless people were routinely swept from the downtown core during large-scale events. In 1990, homeless activists fought to save a low-income single room occupancy (SRO) hotel located across from the Convention Center (Plank, 1990a). When residents were given a 30-day notice to move, they noted that the timing of the eviction suspiciously coincided with the upcoming Goodwill Games (Winfield, 1990). Although housing groups eventually passed a relocation ordinance, they were becoming concerned that "relocation assistance won't do any good if there's no place to move to" (Nelson, 1990, E3).

By mid-decade, the sweeps against the homeless during mega-events escalated into proposals to permanently remove the homeless from downtown by criminalizing behaviors such as sitting on the sidewalk and panhandling (Angelos and Birkland, 1993). In 1994, the city bulldozed a long-standing homeless community known as "The Jungle" that was located on a wooded hillside near downtown (Ho, 1994, B3). Homeless people no longer felt welcome in downtown Seattle, and they claimed the "tourists are invading our house" (Gonzales, 1995, B1). So in 1995, a homeless activist group called SHARE (Seattle Housing and Resource Efforts) pitched thirty tents on a field near the Kingdome to protest the lack of housing and to "make sure the homeless are not abused" (Gonzales, 1995, B1). One year later, eleven people were 
arrested after they pulled out the newly-planted shrubs from in front of the Seattle Municipal Building to make space for Camp Muni, another tent city (Norton, 1996). By the end of the decade, displacement and the destruction of affordable housing opportunities began to affect residents throughout the city. Tenants in a Capitol Hill apartment building protested when their "rent increased by more than $50 \%$ from $\$ 580$ to $\$ 880 "$ "(Peterson, 1998, B1).

\section{Race: Politics in Black and White in Portland}

In the early 1990s, Portland enjoyed lower housing costs than Seattle. Even when the real estate market boomed in the mid 1990s, housing prices never escalated to the same level that they did in Seattle. While housing was certainly an issue for many Portlanders, race relations were the most prevalent concern in the city. The initial categorization of urban protests does not adequately represent the importance that race played in Portland during the 1990s. Protests about race accounted for $12 \%$ of all local, collective actions in the initial tally. But when protests about education, police brutality and neighborhood issues that have strong racial components to them are considered, the percentage of Portland protests focused on race rises to $21.4 \%$. For example, high school students walked-out of class to protest the transfer of their school's only minority counselor and advocate (Daniels, 1994). While this protest was counted in the education category, these students were confronting racial issues at their school. A similar reconsideration of race and protest in Seattle increases the level of racial justice organizing from $10 \%$ to $12 \%$ of all urban movement activity. 
While race was a serious issue in Seattle, it was a far less significant driver of urban protest activity than it was in Portland during the 1990s.

The Pacific Northwest is a predominately white region. Despite sharing similar demographic trends and linked histories, Portland and Seattle have very distinct legacies of racial discrimination. The Oregon constitution banned blacks from settling permanently in the state and owning property (McLagan, 1980). This clause was not revoked until 1926. Although Washington did not have such a clause, the state was not necessarily any more welcoming to black residents. African-Americans in Seattle, however, always found acceptance among the city's Asian-American communities (Taylor, 1994). When official mechanisms of residential segregation were put into place in the mid-20 $0^{\text {th }}$ century, blacks in Portland were relegated to a few blocks on the inner- east side of the city, while blacks in Seattle were confined in a multi-racial ghetto that also included Japanese and Chinese immigrants (Taylor, 1994; Gibson, 2007).

Few African-Americans had settled along the West Coast until the World War II shipyard boom drew migrants with promises of jobs and opportunities. The explosion of wartime employment fueled a rise in housing construction. Public housing authorities in Seattle built integrated projects for shipyard workers, while Portland's war workers' housing was racially segregated (Taylor, 2007). Once the war ended, Portland city leaders actively encouraged black migrants to leave town, while in Seattle, Boeing and other industries continued to provide well-paying employment opportunities for black workers (Taylor, 2007; Gibson, 2007). By the 
end of the war, half of the black migrants who came to Portland had left, an exodus not repeated in other West Coast cities. By the 1990s, black communities in both Portland and Seattle were hard-hit by the crack epidemic and protests against gang violence, drug-dealing, and police brutality were common. Black business owners in both cities pushed for affirmative-action in local contracting and hiring practices. While neo-Nazi violence was present in both places, white supremacist activity occurred with far greater frequency and intensity in Portland.

Despite these common concerns, protests about racial issues took on a very different character in each city. Much of the racial justice organizing in Seattle took place in 1992 and 1993, after the city experienced two nights of rioting in response to the Rodney King verdict. Although the riot was sparked by the not-guilty verdict in the Southern California police brutality case, young people flooded the streets because they were fed up with conditions closer to home. One young rioter commented: "It ain't Rodney King, it's us" (Angelos et al., 1992, A1). In this regard, the Seattle riots were a local protest movement, even if they were set off by a verdict delivered 1,000 miles away. In spite of a long history of police brutality, no rioting broke out in Portland after the Rodney King verdict. This may have been due to the overwhelming police force that was called out to prevent such incidents; as well as the strict enforcement of youth curfew laws in the days following the verdict (Gilbert et al., 1992). Then again, just two weeks before the Rodney King verdict was delivered, a black man was severely beaten by four white supremacists as he walked to his neighborhood store (Rollins, 1992). Only two of his four attackers were charged with 
a crime. They faced second-degree assault and racial intimidation charges, but the attack was never prosecuted as a hate crime. The persistence of racist violence and local authorities' failure to confront it may have also had a chilling effect on protest in the community.

Harriett Walden, an activist in Seattle's Central District believes that "just because Nazis are no longer marching down the streets with swastikas it doesn't mean that they aren't working towards that same goal" (personal communication, April 7, 2008). In Portland during the 1990s, the goal of the skinhead movement was to create a white homeland in the Pacific Northwest. Although skinhead violence did not occur as often in Seattle, the African-American community was still threatened with expulsion and displacement by other forces in the city. When neighbors in Seattle's Central District organized to oppose the city's get-tough-on-crime Weed and Seed program, which would have sent federal agents to patrol the neighborhood, they saw it as part of a larger fight against the gentrification of the Central District. Residents feared the Weed and Seed program was "a license for open season and wholesale genocide upon black youth and young adult black males" (Lilly, 1992, B3).

Seattle's black community was fighting to defend its space in the city from the forces of gentrification, while, in the beginning of the decade, African-Americans in Portland were struggling to gain representation and recognition for their community. Black community activists fought for educational equity in neighborhood schools. In the 1980s, the Black United Front successfully organized to stop Portland Public School's policy of one-way busing that dispersed black students throughout the district 
(Herndon, personal communication, March 12, 2008). By the early 1990s, the education movement was calling for raising black student achievement levels, granting more community control over neighborhood schools, implementing a multicultural curriculum, and hiring more black teachers and administrators. Portland's black community also fought for the right to rename a street in honor of Dr. Martin Luther King Jr. (Ames, 1990b).

By the mid-1990s, black community organizations in Portland were facing an additional hurdle in their fight for recognition. The city repeatedly denied AfricanAmericans access to public spaces for community gatherings. In 1997, a neighborhood activist who worked with reformed gang members tried to stage an antigang rally and play. She wanted to hold the event in central downtown's Pioneer Courthouse Square (Parker, 1997). The city charged her $\$ 5000$ for a permit to use the space and the rally was subsequently cancelled. The organizer commented: "Basically what they're trying to do is stop the rally from happening. It's just not fair; they totally comered me because they know I don't have that kind of money" (Parker, 1997, 1). In 1998, a similar incident escalated into a small-scale riot. Donald Binns tried to move his annual community picnic to Sellwood Park, which is located in a primarily white neighborhood (Farrell and Trujillo, 1998). This time the city closed the park rather than let the event go on. The picnickers then moved to Irving Park, located in a black neighborhood, and the police again shut down the party, claiming its organizers had not met the proper deadline for applying for a permit. The frustrated party-goers then gathered to protest in front of police chief Charles Moose's home and 
the crowd was once again dispersed, this time with tear gas and billy clubs (Farrell, 1998). While Seattle's African-American community was fighting against the forces of gentrification and displacement, the black community in Portland continually had to struggle to carve out a safe space in the city. By the mid-1990s, blacks in Portland would be also have to confront gentrification and displacement, while continuing their fight for community recognition and representation. 


\section{CHAPTER FIVE \\ THE URBAN SOCIAL MOVEMENT AND EVERYDAY LIFE}

Urban social movement theory developed in isolation from the sociological research on collective action (Pickvance, 2003). As a result, urban movement theory was less concerned with explaining and predicting protest than it was with understanding how movements create social change in cities. But, urban movements first had to be distinguished from other levels of resistance before their impacts could be understood. Manuel Castells (1977) initially viewed urban movements as a neighborhood trade-unions organized to get public goods and services for their communities. Fainstein and Fainstein (1974) saw urban protest as a vehicle that marginalized communities could use to gain incorporation into institutional politics. Castells (1983) later expanded his thinking about urban social movements to include claims for cultural recognition and political autonomy. Katznelson (1981) viewed urban protests as diversionary ethnic and racial politics that kept the U.S. working class divided. Mayer $(2003,2006)$ identified new areas of contention for urban activists, including conflicts between non-profit service providers and their recipients and alliance-building with transnational actors.

Do these descriptions match the goals of urban protesters in Portland and Seattle during the 1990s? This chapter explores questions about the definition, goals and meaning of urban protest in the Pacific Northwest. The narrative data that was gathered from the newspaper articles are used as the basis for testing existing urban movement theory and developing an alternative perspective that better explains the 
cases of Portland and Seattle. The first part of the chapter reviews Castells' (1983) ideas about urban movement goals and describes the gaps that arose when his theory was adapted to this case. The following section introduces an alternative explanation for urban movements that emerged from the analysis of the narrative data about protests in the Pacific Northwest. Urban movements in Portland and Seattle emerged out of the everyday lives of their participants. Next, this concept of everyday life is further explained. The final sections describe the five areas of everyday life that urban movements contested in the Pacific Northwest: labor, collective consumption, neighborhood, urban space, and imagination. The chapter ends with a redefinition of the role that urban movements play in cities.

The City, the Grassroots and the Case of the Pacific Northwest

Manuel Castells (1983) published the only comprehensive theory of urban social movements. He used multiple case studies from three different continents that spanned hundreds of years of time to develop a cross-cultural and historical theory of urban movements. Castells chose his cases randomly, and some of the most wellknown examples of revolutionary urban movements are among them, like the Madrid Citizens' Movement the Glasgow Housing Movement. As a result of this case selection, Castells concluded that urban movements have lofty goals for cities. Not only do urban movements struggle to resist capital, but they also challenge the state and technocracy. Castells identified three broad goals that urban movements work towards: collective consumption, political autonomy and cultural recognition. These 
three goals were used to code the narrative data that was collected from the protest event articles about Portland and Seattle.

Even though Castells' categories were general enough to explain many social movement goals, some of the urban protests that took place in Portland and Seattle during the 1990s did not fit into his typology. Three types of protest in the Pacific Northwest struggled for goals other than collective consumption, political autonomy or cultural identity. These three types of protest included: urban labor movements, some neighborhood-based protests, and exclusionary movements. Urban labor movements in the Pacific Northwest were not organized around demands for collective consumption resources, community-control of the political system, or cultural recognition. Instead these groups fought for the right to earn a living and to improve working conditions and compensation. Castells claimed that urban movements existed separately from class-conflicts. He defined urban movements as "multi-class" efforts that aim to alter "relationships of consumption, communication and power" (Castells, 1983, 320). Yet in the case of the Pacific Northwest, labor activism met all of the criteria necessary to define it as an urban movement. Urban labor protests were sparked by local working conditions, targeted at local businesses or political institutions, and organized by grassroots organizations.

The second category of protest that did not share Castells' (1983) goals was some neighborhood-based movements. At times, communities organized to get fight drugs or gangs in their neighborhood. This type of activism was not a call for greater cultural autonomy or even an effort to gain control over local political institutions. 
Instead, these movements wanted to change the behaviors of their fellow community members. They fought to improve the quality of life in their communities by joining together to make them safer places to live.

The final group of protests in the Pacific Northwest that failed to meet Castells' (1983) three criteria was exclusionary movements. These movements organized to exclude particular groups from their communities. While many of these movements, like the skinheads, sought to impose an oppressive order on the city, others' fought to defend themselves from exclusionary groups. For example, the gay and lesbian community rallied to oust a religious group that organized a picnic in a Seattle park. The community protested the "occupation" by "right-wing Christians" of a park in the city's most gay-friendly neighborhood and viewed the picnic as a direct provocation (Kuebelbeck, 1990, A5). Protests like this defied ready-made definitions about fighting capital, the state and technocracy.

When these three grandiose goals that Castells (1983) identified failed to explain urban social movements in Portland and Seattle, it was clear that a new approach was needed. A re-examination of the narrative data using an inductive coding schema revealed that urban social movements in the Pacific Northwest grew out of the everyday life experiences of their participants. For example a protest of Filipino workers at a public hospital in Seattle demanded that supervisors rescind a new rule that forbade them from speaking Tagalog at work (Lewis, 1990). This rule posed an immediate threat to they way these workers thought, communicated, and conducted their daily routines. Students and families at Hollyrood Elementary School 
marched through their Portland neighborhood, riding bikes and singing songs when the district threatened to close their school (Gardner, 1994). Families were upset that their children would have to attend a much larger school and ride a bus to get there. Homeless people living under a bridge refused to move when the Portland police arrived to sweep their camp, and the gay and lesbian community demanded an apology when a Seattle paper ran a homophobic cartoon (Pratt, 1995; "Groups Protest Editorial Cartoon," 1996). The homeless were literally defending their space in the city, while gays and lesbians fought to symbolically secure their place in the community. French sociologist, Alain Touraine remarked that "social movements are not dramatic and exceptional events; they are in permanent form at the very core of social life" (Castells, 1983, 289). The movements that took place in Portland and Seattle during the 1990 s ushered in no revolutionary change, nor will they likely be among those chosen for future study, but these actions grew out of and had influence on the daily lives of urban dwellers in the Pacific Northwest.

Five areas of contention emerged from the analysis of the narrative protest data: labor, collective consumption, neighborhood, urban space and imagination. These five areas represented different aspects of everyday life that urban protesters in the Pacific Northwest addressed. Protesters confronted issues in their workplaces, neighborhoods and with the public services the city provided. Social movements challenged the production of urban space as well as the identity of the city imagined by its citizens. 
Table 5-1 outlines the main themes that were evident in each of the five areas of everyday life that protesters confronted in the Pacific Northwest. The second column compares these themes to the three goals that Castells (1983) outlined in The City and the Grassroots. Castells' goals overlapped in most of these areas, and some of the demands that protesters made in Portland and Seattle did not match any of Castells' demands.

Table 5-1

Five Aspects of Everyday Life Evident In Pacific Northwest Protests 1990-1999

\begin{tabular}{lll} 
& \multicolumn{1}{c}{ Protests Themes } & Castells' Goals \\
\hline Labor & $\begin{array}{l}\text { Living Wage } \\
\text { Right to Earn a Living } \\
\text { Better Working Conditions }\end{array}$ & Collective Consumption \\
\hline Collective & $\begin{array}{l}\text { Value of and demand for } \\
\text { Social goods and services } \\
\text { Equality in provision of } \\
\text { services }\end{array}$ & $\begin{array}{l}\text { Collective Consumption } \\
\text { Cultural Identity }\end{array}$ \\
\hline Neighborhood & $\begin{array}{l}\text { Safety } \\
\text { Construction and defense of a } \\
\text { home territory }\end{array}$ & $\begin{array}{l}\text { Collective Consumption } \\
\text { Political Autonomy }\end{array}$ \\
& $\begin{array}{l}\text { Right to determine use of } \\
\text { neighborhood }\end{array}$ & \\
& space & \\
\hline Urban Space & $\begin{array}{l}\text { Conflicts over how space is } \\
\text { imagined, produced and used } \\
\text { Right to occupy city spaces }\end{array}$ & $\begin{array}{l}\text { Collective Consumption } \\
\text { Political Autonomy } \\
\end{array}$ \\
& $\begin{array}{l}\text { Recognition of communities } \\
\text { in the collective }\end{array}$ & Cultural Identity \\
\hline Imagination & $\begin{array}{l}\text { representations of the city } \\
\text { Right to tell our story }\end{array}$ & \\
&
\end{tabular}

\section{The Concept of Everyday Life}

Urban movements in the Pacific Northwest grew directly out of the everyday lives of their participants. The philosophical concept of everyday life was explored during the 1920 s by Martin Heidegger and Georg Lukács; it was more fully developed 
in a three-volume text by Henri Lefebvre (Sheringham, 2006). Lefebvre (2005b) critiqued sociology's tendency to divide everyday life up into separate, seemingly disconnected facets like work, religion, and family. He instead sought to join these social relationships into one unitary category that more aptly reflected the ways in which we experience our lives and broader social structures. Lefebvre claimed: "It is in everyday life that the collection of relationships that constitute human reality and each individual as a totality are formed" (Lefebvre, 2005a, 109). To Lukács, "everyday thinking" was all that was commonplace and routine devoid of artistic, creative and higher order contemplation (Sheringham, 2006, 36). Lefebvre instead argued that everyday life was not merely the remainder of life devoid of its higher pursuits but the "nourishing soil" of all artistic and revolutionary human interaction (Sheringham, 2006, 140).

Despite later theoretical developments that connected the concept of everyday life with cultural and consumption studies, Lefebvre's quest to create a theory of daily human experience was a deeply political project that he viewed as an extension of Karl Marx's original work (Roberts, 2006). Although "the mode of production entails a mode of existence," the realm of everyday life is not solely a space of alienation (Lefebvre, 2005c, 162). To Lefebvre, everyday life held not only the source of our alienation, but also the capacity for the re-appropriation of our lives (Sheringham, 2006,140 ). In everyday life, the seeds of transformation and resistance are sown "not because of the content" of our daily lives "but because of the processes and relationships that are fostered there" (Sheringham, 2006, 141). Building on the work 
of Lefebvre, Maurice Blanchot noted that it is through the triviality of the everyday that resistance is awakened:

The everyday is no longer the average, statistically established existence of a given society at a given moment; it is a category, a utopia and an idea, without which one would not know how to get at either the hidden present, or the discoverable future of manifest beings (Blanchot in Roberts, 2006, 76).

That transformation of everyday life from the inconsequential to a fragile utopia is the project of urban social movements. Castells recognized that potential that urban movements have to "nurture the embryos" of future resistance (Castells, 1983, 313). Lefebvre insisted that "the revolutionary process begins by shaking up the conditions of everyday life and ends by restoring it" (MacDonald, 2006, 76).

In order to examine urban social movements from an everyday life perspective, meta-theory about social structure must be temporarily set-aside. The everyday is experienced on a small local scale, and theoretical constructs that tend towards globallevel explanations about social processes, and institutions do not fully capture the intimate interactions and narrow routines that make up the experience of daily life. Everyday life is constructed by larger-scale processes but it is not experienced as such.

The urban social movements in this case study shook up the conditions of daily life in Portland and Seattle during the 1990s. Urban movements in the Pacific Northwest contested five areas of everyday life: labor, collective consumption, neighborhood, urban space, and imagination. These movements conflicted over the 
collective consumption issues that Castells (1983) identified, but they also sought to challenge social relationships at work and in their neighborhoods. In addition, protesters in the Pacific Northwest contested the use and construction of urban spaces and confronted the community's imagination and the identity of their cities. While protesters often echoed Castells' (1983) calls for collective consumption, cultural identity, and political autonomy, the demands he associated with urban movements did not discretely fit any particular category of everyday resistance.

\section{Urban Labor Protests}

Labor conditions are set by those who have access to capital and imposed upon those who do not. However in everyday life, workers do not experience their labor as surplus-value for capital. Labor is experienced as a necessary action for survival, as well as the primary framer of daily rhythms and routines. For example, social workers with the Child Protective Services Division in Portland staged a coffee break demonstration to protest their "ferocious workload" (Oliver, 1990, D15). The workers were "living in a continual state of fear because of heavy workloads," and they "worried about families served and their own health" (Oliver, 1990, D15). Although the increase in caseloads was predicated by neoliberal restructuring and declining state budgets, workers saw only the smaller picture. Their caseloads were encroaching upon their leisure time as well as their work routines. This disruption of their daily lives, rather than opposition to a neoliberal ideology, led to the coffee-break demonstration. 
Labor protests made up 14\% of all urban movements in Portland and $18 \%$ in Seattle. For a labor protest to be considered "on the city," it had to be directed at area businesses or city institutions, sparked by local labor conditions and organized by urban workers (Fontan et al., 2007). Not only did these protests occur on a different geographic scale than other labor actions, they had distinct goals, strategies and targets that set them apart from most larger-scale labor movements.

Urban labor protesters shared the same goals that workers in state-wide and national movements desired; they wanted to improve wages and working conditions. However, urban labor activists were rarely represented by unions, and when they were, they often engaged in wildcat strikes or actions. Convenience store workers in Seattle organized a mass occupation of their mini-mart to force the owner into negotiating with them for better wages ("West Seattle Mini-Mart," 1996). Electrical workers at the Portland branch of PG \&E were concerned about the company's lack of attention to safety, so they picketed before and after work to avoid violating their contract (Goranson and Kohler, 1994).

Urban labor protesters were more likely to be affiliated with community-based workers' organizations than with national unions. The Red Lion hotel workers who protested the use of toxic cleaning chemicals in their workplace were supported by the Hotel Workers' Organizing Committee (HWOC), a group affiliated with, but autonomous from, the local union (Williams, personal communication, February 5 , 2008). Workers' organizations like the HWOC are community-labor partnerships. Community-labor partnerships are organization based outside of the workplace for 
workers' rights. These partnerships played a strong role in early labor history. Before workers won the right to collectively bargain, they relied upon popular support to gain better wages and working conditions (Brofenbrenner, Friedman, Hurd, Oswald and Seeber, 1998). The community-labor partnerships have made resurgences in the postindustrial United States. A majority of workers are now employed in service sector jobs, which offer lower pay, fewer benefits, less job security and lower unionization levels than manufacturing industries. Service sector jobs are more decentralized than manufacturing, workplaces may be located throughout the metropolitan area, and subcontracting relationships are common (Savage, 2006). In service industry workplaces, employees' shifts vary in length, they rarely have set break-times or central places where workers gather. This new geography of service sector work forced labor organizers find new ways to connect with workers. In addition to the changing geographies of the workplace, there was also a diversification of the workforce (Sassen, 1991). Women, people of color, and immigrants make up the majority of the service sector. This changing workforce has changing needs. When the HWOC organized immigrant workers at the Hilton, they had to find safe spaces for workers to assemble in because many refugees feared employer retaliation. Workers often met in community gathering places, like churches, temples, or refugee centers (CervantesGautschi, personal communication, January 24, 2008).

Relationships between workers, employers and customers also differ in service industries. The pace, production, compensation and conditions of manufacturing work are all controlled by the management. In the service industry, working conditions are 
often directly dictated by consumer demands. Service industry workers can negotiate with their employers over the percentage of profits they receive, but control over the routines and rhythms of their work lies with the customer. This tripartite relationship complicates labor/employer relations, but it also provides fertile grounds for creating new alliances. When grocery workers struck in Portland in 1990, they relied upon the support of their loyal customer base. One butcher commented: "It's different because they're not going to move grocery stores overseas, it's not like an airline or factory. We know the customers; they are our neighbors and friends" (Phelps, 1990, 13).

These changing labor relationships not only created new alliances for urban workers, they also produced different targets. Because the service industry is so decentralized, protesters frequently demanded that the state intervention through regulation. When the Seattle taxi-drivers struck during the WTO meetings, they targeted the city, not cab companies (Robin, 1999). The city's regulation of local economic activity also determines who can earn a living. Day-laborers in Portland protested for the right to solicit odd jobs on the comer without police harassment (Rivero, 1998). Minority contractors rallied for their fair share of work from government sources and the Black Dollar Days Task Force in Seattle organized a day of support for black-owned businesses (Gupta, 1990; Kiyomura, 1992b; Strickland, 1992).

\section{Collective Consumption Protests}

Castells (1977) defined collective consumption as the distribution of social goods and services. To service recipients, having access to institutions like schools, 
public transit, or youth shelters is a taken-for-granted part of daily life. To a political economist, these services help reproduce the labor force, but recipients do not perceive them that way. Instead these structures organize service recipients' lives, much in the same way that labor determines the daily routines of workers. Children's routines are structured around their school day. When this rhythm of daily life is disrupted, as it was in the case of Hollyrood students after the district threatened to close their school, service participants may turn to protest (Gardner, 1994).

Manuel Castells (1977) coined the term 'collective consumption trade unions' to describe what he initially saw as the role that urban social movements play in cities. Protests over collective consumption resources accounted for $13 \%$ of all urban-based actions in the Pacific Northwest during the 1990 s, including $18 \%$ of all urban protests in Portland and $9 \%$ in Seattle. These protests were usually led by consumers of public services. They protested to improve the quality and distribution of social goods and benefits.

Securing educational services was a major goal for collective consumption protesters in the Pacific Northwest. Students were leaders in the movement to protect educational funding. In 1998, young people in Portland walked out of their schools to protest budget cuts brought on by the passage of a statewide anti-tax measure (Heinz, 1996; Hernandez, 1996). Nearly half of all collective consumption protests in the urban Pacific Northwest were organized by youth. Youth were most likely to be involved in protests over education, but they also participated in housing actions and organized to prevent cuts to youth-oriented programs. 
Many times, youth were supported in these struggles by their parents and families. Families who participated in collective consumption protests demanded that the city take responsibility for ensuring the well-being of children and youth. Worthy Wages was a coalition of child care providers, parents, and advocates who organized a march to raise day-care workers' pay in Seattle. One marcher commented: "I support the day-care workers getting increased wages, not necessarily from the parents because they're pretty maxed out, but from the government and employers" (Broom, 1991, E2).

Collective consumption protesters not only fought for the increased provision of publicly produced goods, they also struggled for fairer distribution of those local services. Collective consumption protesters often addressed racial inequalities in service provision. In 1991, the Black United Front staged a one-day boycott of Portland Public Schools to protest the district's failure to provide an adequate education for black students (Graves et al., 1991). High school students in Seattle protested the disparate disciplinary treatment of minority students (Fitzpatrick, 1998). One-third of all collective consumption actions in Portland were about race. However, other communities also made claims for better services. In 1998, late-shift workers marched through downtown Portland to demand more frequent night bus routes and schedules (Stewart, 1998).

\section{Neighborhood Protests}

To theorists, the neighborhood is considered a site of social reproduction. To residents, neighborhoods are not important for the role they play in supporting and 
replicating the labor force, instead communities are valued for the social bonds they help create and sustain. Although neighborhood politics are often dismissed as parochial or divisive, the activists that organize these actions are primarily driven by a desire to protect and defend their families and communities (Katznelson, 1981; Merrifield, 2000). While neighborhood activism can be exclusionary, it also displays some of the elements of traditionalism and protectionism that are thought to define pre-capitalist life (Gans, 1962). When a paroled sex-offender moved into a southeast Portland neighborhood, residents vandalized his house and rallied to force him to move out. Neighbors felt their actions were necessary to protect their children, but some worried that the protests signaled a return to the changing area's "old mentality, a mob mentality" (Amick, 1996, C2).

Neighborhood protesters in Portland and Seattle fought for greater control over their communities. They came together to protest unwanted businesses, unfair treatment, proposed cuts to city services, and the behaviors of deviant community members. Neighbors tried to drive out businesses that were perceived to be threats to the safety, livability, or economic value of their communities. Portlanders rallied to shut down an adult motel after a young girl was raped and killed there. They demanded that the owner "get out of our neighborhood" and claimed there should be "no sleaze near schools" (Wee, 1993, C11). Protests against sex shops and adult bookstores were common in Portland, where state law prohibits zoning against adult businesses (Pickett, 1990). For many neighbors, the fight to control the content of businesses in their community was an extension of their desire to create a safe haven 
for their children. When residents in Mt. Scott protested Gentleman's Tan, they proclaimed: "This is a family neighborhood" (Steele, 1994, C5). They also worried that the proximity of adult businesses reflected poorly on the community as a whole: "People in greater Portland think we don't care in this area. We want to say we do care" (Steele, 1994, C5).

Neighbors also organized against businesses that treated community members unfairly. Residents of the Columbia City neighborhood in Seattle picketed a Safeway store where a security guard killed a man who had shoplifted a pack of cigarettes (Angelos, 1994). Neighbors who shopped at $15^{\text {th }}$ Avenue Market in Portland boycotted the store after a community member and longtime employee was fired (Axely, 1993). Residents in Seattle organized against a medical waste incinerator and that compromised their community's health and well-being ("Protest at Northwest Hospital," 1999).

The safety of neighborhoods was not only threatened by unfriendly businesses, sometimes residents or outside elements posed a threat to the community. The inhabitants of Seattle's Central District protested at apartment buildings where known drug dealers were living (Clutter, 1990; Angleos, 1990). They planned to "go to other drug infested homes and even to the landlords' homes if necessary to get results" (Clutter, 1990, B2). Neighbors in nearby Capitol Hill organized a foot patrol to police the area after a rash of gay-bashings (Lewis, 1991). The Q-Patrol was "not a loudmouth, militant group of people marching up and down with our slogans, the 
group's purpose is to promote safety and stop violence against gay men and women" (Lewis, 1991, B4).

\section{Urban Space Protests}

Urban space is constructed by local leaders to serve the needs of domestic and global capital, but to it is also the skeleton that gives everyday life its structure (Lefebvre, 1991). The built environment not only determines the opportunities there are for participation in the labor force, it also impacts the quality of life in neighborhoods. Urban space encompasses all of the paths we travel on to carry out our daily routines, and changes in the built environment can disrupt our habits and impact other aspects of daily life. In 1999, artists in downtown Seattle organized a gallery show to protest their displacement from downtown neighborhoods. The artists claimed: "We don't ask for any special treatment, we don't see ourselves as different from the guy down the street. Like the Korean grocer, like the independent coffeehouse we're just busting our chops to survive" (Rose, 1999, F3). To these artists, access to downtown studio space was essential for their professional survival.

Control over the production of urban space was a key demand for local social movements in Portland and Seattle during the 1990s. Protests that fit into this category contested the design, decision-making, and use of the built environment or struggled for safe and equitable access to the public spaces of the city. Conflicts over urban space were by far the most numerous category of local protest in the Pacific Northwest. Urban space protests accounted for $42 \%$ of local contentious 
action, including $47 \%$ of all urban protests in Seattle and $38 \%$ of conflicts in Portland. Protests over urban space reflected the larger issues in each of these cities. Prior to $1995,96 \%$ percent of all urban space protest in Portland was connected to the ongoing conflicts between the right and left over gay and lesbian rights, abortion, and race.

In Portland, protests about urban space were key clashes in the larger struggles for community and cultural recognition. Controlling urban space was a crucial demand for both the right and the left. The right-wing recognized the importance of occupying urban space and organizations like Advocates for Life and the Oregon Citizens' Alliance continually pushed the boundaries of free speech rights in public areas. Neo-Nazi skinheads used violent attacks to promote fear, and therefore control urban space.

The left responded in different ways to this right-wing offensive. Anti-racist organizers embraced the battle over urban space by actively and militantly confronting skinheads and white supremacists. The gay and lesbian movement used civil disobedience tactics to demonstrate their strength, survival and pride in the face of a number of homophobic initiatives. They also took their conflict to the spaces of the right, disrupting the church services at the Portland Foursquare temple and protesting at OCA rallies (Oliver, 1991; Rubenstein, 1991). The women's movement was more hesitant about directly challenging right-wing protesters' use of public space. Women's health care providers relied on the courts or police to enforce a safe perimeter around clinics. Clinic defenders did escort patients through anti-abortion 
protesters' blockades but were reluctant to confront the movement in their own spaces. In 1998, thirty-three women protested at the Good Shepherd Church, where many anti-abortion protesters worshipped. One young parishioner commented, "It was weird having them come here instead of us going there" (Scott, 1998, E2).

While Portlanders protested for recognition, urban space conflicts in Seattle centered on redistributive demands. Fifty-nine percent of all urban space movements in Seattle dealt with housing issues. These movements fought against the destruction of low-income housing in downtown neighborhoods, struggled for the rights of homeless people and contested the gentrification process. The housing crisis in Seattle was becoming so severe that finding and keeping an affordable unit was the paramount struggle in many people's everyday lives. One homeless protester remarked:"There are so many people out here (on the streets) for everyday reasons, these things that could happen to anyone" (Plank, 1990, B1). The everyday hustle to pay the rent was an invisible struggle that was far removed from the consciousness of politicians and better-off Seattle residents. It was through the occupation of public space that the housing crisis entered the public's awareness.

Urban space protesters were engaged a battle over the use-value and the exchange-value of the built environment. In 1990s Seattle, it appeared that exchangevalues were triumphing. One protester who demonstrated against the demolition of the historic Music Hall building cried as it was torn down, "It feels like breaking bones, my bones" (Balter, 1991, A1). The loss of the historic Music Hall was emblematic of a larger trend that worried activists: 
This makes a profound statement about the apathy of Seattle. Seattle sold out to money-grubbing corporate greed. If we can tear something like this down that means we can tear down the Smith Tower and the Paramount. There isn't any historical building in Seattle that's safe now (Balter, 1991, A1).

\section{Imagination Protests}

Some conflicts in Portland and Seattle addressed less tangible realms of daily life. Protesters clashed over the collective imagination of their respective cities. Imaginative life in the form of stories and memories about a place helps create its identity. Place-identity determines who belongs and who does not. Belonging to a place gives a group the right to participate in all other aspects of daily life, from living in urban neighborhoods to accessing social services and employment to occupying public space. In 1991, Queer Nation leafleted a Seattle high school to support its gay and lesbian students (Brown, 1991). These students were fighting for recognition in their school community. Establishing the right to belong in high school was the first step toward incorporating appropriate student services and ensuring the right to safely walk through the halls.

Protests over the collective imagination of the city comprised the smallest category of urban movements, making up only $7 \%$ of protests on the city. Portland was home to more of these movements than Seattle. Protesters organized to create a more inclusive place-identity and to incorporate their stories into the city's collective imagination. Conflicts over the imagination of the city challenged dominant historical 
narratives. When the $150^{\text {th }}$ anniversary of the Oregon Trail was celebrated, Native American groups set up a protest encampment to contest their omission of from the story. In their experience: "It really wasn't an Oregon trail. It was an Indian trail first. The end of the Oregon Trail led to the death and oppression of native peoples, decimation of ancient forests, and the decline of biodiversity" (McNichol, 1993, C2). In addition to conflicts over historical narratives, protesters also challenged urban festivals that celebrate and perpetuate the collective identity of the city. In Portland, women contested the annual Rose Festival pageant (Eure, 1994).

The collective identity of a place is not only produced through its historical representations and traditions, it is also constructed in the media. Media was a target for many imagination protesters. Seattle University students held a rally to object to a racist cartoon in their school's newspaper ("Students Charging Racism," 1992). Gay and lesbian groups also objected to biased media portrayals as did women's organizations (Bradford, 1994; McFarland, 1999).

In 1990, a shadowy organization known only as Group X changed the street signs on Portland's Front Avenue to Malcolm X. Ave. This action, which occurred in conjunction with the diversity rallies held during the Metzger trial, was intended to "force people to think about the issue" (Gragg, 1990, B1). Seattle activists also modified signs to make a political point. After opponents to a plan to publicly finance a new sports stadium received little media attention, seventeen billboards were altered with anti-stadium messages (Plank, 1990). 


\section{Role urban social movements play in everyday city life}

Table 5-2 displays the goals, targets, and tactics that protesters used, as well as the police response they received in each of the five areas of everyday life that urban movements contested in the Pacific Northwest. Protest goals refer to the demands that activists articulated in their words and actions. Urban protesters' goals fell into three general categories that closely mirrored the broad demands outlined by Castells (1983). Urban protesters fought for community-control, but in the Pacific Northwest this demand was more than just a call for greater political autonomy as Castells had envisioned. To many neighborhood protesters, community-control meant the right to define and defend a home territory. The second goal that urban protesters struggled for was recognition. In Castells' cases winning the right to cultural autonomy meant gaining political representation for your community. Pacific Northwest protesters fought to create a tolerant city where all communities could safely occupy public space. Collective consumption protesters demanded equality in the provision of public services, and imagination protesters wanted their city's identity to reflect all of its residents' diverse experiences. The third goal that urban protesters fought for was better access to resources. Activists in Portland and Seattle organized to gain more than just those resources that publicly distributed and collectively consumed, they wanted a greater share of business profits and the right to enjoy a living wage.

Even though Pacific Northwest protesters shared many of the same goals as Castells' (1983) case study movements, a much broader range of urban institutions were targeted in Portland and Seattle. The targets of protesters in each category are 
Table 5-2 Characteristics of Protest Each of the Five Aspects of Everyday Life

\begin{tabular}{|c|c|c|c|c|c|}
\hline & Labor & $\begin{array}{l}\text { Collective } \\
\text { Consumption }\end{array}$ & Neighborhood & Urban Space & Imagination \\
\hline Goals & $\begin{array}{l}\text { Transformation } \\
\text { of local labor } \\
\text { relationships, } \\
\text { Access to } \\
\text { goods } \\
\text { necessary for } \\
\text { survival }\end{array}$ & $\begin{array}{l}\text { Access to } \\
\text { collectively } \\
\text { produced goods } \\
\text { and service, } \\
\text { equality in } \\
\text { service } \\
\text { provision }\end{array}$ & $\begin{array}{l}\text { Creation and } \\
\text { defense of a } \\
\text { home territory }\end{array}$ & $\begin{array}{l}\text { Urban space } \\
\text { as use-value, } \\
\text { control over } \\
\text { production of } \\
\text { urban space }\end{array}$ & $\begin{array}{l}\text { Inclusion in } \\
\text { collective } \\
\text { identity of } \\
\text { the city, tell } \\
\text { our story }\end{array}$ \\
\hline Targets & $\begin{array}{l}\text { Capital and } \\
\text { local state }\end{array}$ & $\begin{array}{l}\text { Local state, } \\
\text { public } \\
\text { institution or } \\
\text { service } \\
\text { provider }\end{array}$ & $\begin{array}{l}\text { Neighborhood } \\
\text { businesses, } \\
\text { rogue } \\
\text { community } \\
\text { members, city, } \\
\text { outsiders }\end{array}$ & $\begin{array}{l}\text { Police, city, } \\
\text { planners, } \\
\text { rogue } \\
\text { community } \\
\text { members }\end{array}$ & $\begin{array}{l}\text { City, } \\
\text { media, } \\
\text { festival }\end{array}$ \\
\hline Tactics & $\begin{array}{l}\text { Strikes and } \\
\text { Pickets }\end{array}$ & $\begin{array}{l}\text { Walk outs } \\
\text { (strikes for } \\
\text { service } \\
\text { recipients) }\end{array}$ & $\begin{array}{l}\text { Isolating threats } \\
\text { and claiming } \\
\text { territory: } \\
\text { Pickets, Rallies, } \\
\text { Marches }\end{array}$ & $\begin{array}{l}\text { Occupy } \\
\text { urban spaces }\end{array}$ & $\begin{array}{l}\text { Tell our } \\
\text { stories, } \\
\text { change } \\
\text { symbols and } \\
\text { signs }\end{array}$ \\
\hline Repression & $\begin{array}{l}\text { Arrests occur } \\
\text { when } \\
\text { protesters } \\
\text { occupy space }\end{array}$ & $\begin{array}{l}\text { Arrests occur } \\
\text { when protesters } \\
\text { occupy space }\end{array}$ & No arrests & $\begin{array}{l}\text { Police } \\
\text { involved in } \\
\text { one-quarter } \\
\text { of all } \\
\text { protests. } \\
\text { Higher than } \\
\text { average } \\
\text { arrests. }\end{array}$ & $\begin{array}{l}\text { Arrests only } \\
\text { when } \\
\text { property } \\
\text { damage } \\
\text { occurs }\end{array}$ \\
\hline
\end{tabular}

listed in Table 5-2. Castells claimed that urban social movements struggled against

capital, the state and technocracy, but his case studies only targeted their city's

political institutions. Urban protesters in Portland and Seattle not only targeted city

hall, but they also organized against local businesses, service providers, the media, and rogue community members. Pacific Northwest urban movements were not solely concerned with local politics, nor did they worry about their city's place in the larger world. Instead, they tried to make changes on the micro-level, in their day-to-day routines, and in their ability to define their place in the city. 
Local protesters in Portland and Seattle used were the same tactics as largerscale mobilizations, but they occasionally employed them in different contexts. Table 5-2 lists the primary tactics that were used in each category of protest. Urban labor protesters used strikes and pickets, but so did the consumers of public services. Neighborhood protesters conducted pickets to literally surround an offending business, residence, or community service provider. In addition to pickets, neighborhood protesters organized marches. These were not large-scale parades designed to generate publicity for a particular issue or position, but rather efforts to move through and recapture neighborhood space from rogue community elements. Occupation was the tactic favored by urban space protesters. In larger-scale protests, occupations are traditionally used to force the protest target to listen to a group's demands. In this case, the occupied buildings were themselves the targets of many urban space protests. Urban protesters in these five areas faced a variety of police responses. Table 5-2 just measures police repression in terms of activists' arrests. The only category of protest where no arrests were made was neighborhood protests. Labor, collective consumption, and imagination protests attracted a lower than average arrest level. Urban space protesters attracted a higher than average rates of arrest. One-quarter of protests over urban space resulted in arrests, compared to a $16 \%$ average arrest rate for all protests in the Pacific Northwest. Clearly, the occupation of urban space was threatening to the city's status quo. Not only were urban space protesters disproportionately likely to be arrested, but the police were only called to labor or collective consumption protests when activists occupied public or privatized space. 
The police cleared out a homeless encampment in front of Portland's City Hall and arrested nurses who occupied a closed hospital demanding back-pay (Brown and Poore, 1990; Kiyomura, 1992a).

In order to understand the role that urban social movements play in cities, it is first necessary to define how cities function. The city is more than just a territorially bound entity; it is a web of complex social interactions and relationships that produce and are produced by a particular spatial regime (Lefebvre, 1991). The magnitude of space as a producer of social relationships is illustrated by both Portland and Seattle's wholesale repression of urban space protesters. Cities use space to promote particular ideologies and to define who belongs to a territory and how they can participate in social life (Davis, 1990; Mitchell, 2003). Spatial patterns also constrict and organize the day-to-day routines of urban dwellers (Lefebvre, 1991). How a city organizes its space will determine its political, economic, and to a lesser extent, its cultural organization. But the production of urban space is not only a top-down program; it is a process that is constantly contested. Urban social movements play an integral role in shaping cities' spatial regimes. Movements contest dominant spatial patterns, appropriate new uses for existing spaces, and create altemative urban space. When movements succeed in overturning an existing spatial regime, they produce new patterns in people's daily lives. Through this process, urban movements expand the boundaries of their constituents' everyday lives.

Urban social movements make demands for greater political autonomy, access to public resources and cultural recognition, but these claims are not only directed at a 
city's political institutions (Castells, 1983). Instead, urban protesters organize to confront their adversaries in the places where they experience injustice: their workplaces, neighborhoods, local institutions, the built environment, or the collective imagination of their city. Often times these protesters target the state and other political entities, but not always. Sometimes the adversaries of urban movements are other community members, local business owners, or public service providers.

Urban social movements do not wage these local-level conflicts to transform the urban meaning of their cities, although occasionally protesters do articulate such revolutionary demands. However, the primary role that grassroots movements play in the city is to transform the daily lives within their participants' community. Urban protesters are care concerned with their community's place in the city than the city's place in global institutions and social structures. While protesters may be aware of the role that larger institutions play in constructing local relationships, urban social movements struggle to transform relationships within the city, not beyond it.

The second section of the dissertation delves deeper into these questions about cities, space and everyday life. It explores how five urban movements impacted the lives of their constituent communities in Portland and Seattle. These movements represent each of the five aspects of daily life that protesters contested in the Pacific Northwest. The five case study movements are: Portland's Hotel Workers Organizing Committee, the Black United Front's boycott of Portland public schools, the Seattle neighborhood coalition that challenged the implementation of the Weed and Seed 
policing program, the downtown building occupations by Operation Homestead in Seattle, and the protesters who challenged Portland's Rose Festival pageant. 


\section{PART II \\ "OUR STREETS!" \\ THE IMPACT OF URBAN \\ SOCIAL MOVEMENTS ON DAILY LIFE}




\section{CHAPTER SIX \\ HOW URBAN SOCIAL MOVEMENTS MATTER: MEASURING THEIR IMPACTS ON EVERYDAY LIFE}

On a stormy January day, a group of street kids camped out in front of Portland City Hall to protest the lack of shelter space for youth (Kiyomura, 1992a). This small protest of a few disheveled young people with a shopping cart full of belongings soon grew into a full-scale encampment replete with eloquent spokespeople, never-ending donations of food and blankets, and plenty of sympathetic well-wishers. The young people wanted the city to convert an old armory building into a shelter and stop the police harassment of homeless people. One homeless activist, who was a veteran of earlier encampments, issued a flyer that read, "We are against a society that allows grinding poverty amidst grandiose wealth" (Heinz, 1992, C1). The protesters called for better medical care, more shelters, nutrition and job-training programs and a repeal of the city's anti-camping ordinance. The protest slowly lost some of its steam and ended with the police breaking-up the encampment and beating and arresting many of the demonstrators. All the protesters won were expanded youth shelter hours and promises to pursue an increase in shelter beds, but they believed they had "accomplished a lot...[p]eople are saying, wait these kids want something although they're not necessarily sure what we want or need" (McDermott, 1992, C3).

This chapter examines how the impacts of urban movements, like the street kids' protest, can be measured. The first section reviews the existing theory about how local movements impact cities and introduces the collective identity approach to social movements. The second section argues for a community-level analysis of urban 
social movement impacts. In the final section, four criteria are created to measure the areas of everyday life that urban movements can transform.

\section{Urban Movements, Communities, the City, and Change}

Although Portland's homeless youth activists felt their protest was a success, most social movement theorists would be hard-pressed to identify an outcome from their actions. No major policy changes were initiated, the anti-camping ordinance still stood, and the city government remained unsympathetic to the needs of the desperately poor. The electoral and policy outcomes of protest are the primary focus of most social movement scholars. Alberto Melucci (1989) argued that only looking at the political outcomes of protest devalued new social movements and other revolutionary efforts to create cultural change. New social movements are less concerned with making political changes than they are with creating new identities and meaning for their participants. Collective identity theory analyzes social movements from the perspective of activists, rather than through its structural context (Mayer and Bartholomew, 1992). The creation of new identities and meaning for participants and their adoption into mainstream culture are emphasized. Collective identity theory was criticized for its omission of one of the most important and defining aspect of social movements, their public performances (Tilly, 1999). The focus on collective identity as the primary outcome of social movement activity makes it difficult to differentiate movements from other forms of collective action, like subcultures or fads. Melucci's conclusions about movements' production of new collective identities and meanings were also critiqued as culturally and historically biased (Mayer and Bartholomew, 
1992). His analysis was based on observations of post-industrial Italian movements and was limited by his focus on new social movements, which are primarily First World middle-class mobilizations.

Although Melucci's approach is problematic, he drew attention to a serious shortcoming in social movement studies. Movement success is commonly equated with policy outcomes, electoral changes or political party formation. According to these criteria, movements like the street kids' protest in Portland are failures. Urban social movement scholars were more flexible about identifying possible movement outcomes. Manuel Castells (1983) designed a triad of classifications that could be used to evaluate urban social movement impacts. He declared that movements affect urban form, function and meaning. Castells argued that urban social movements are only successful if they are able to change urban meaning.

Castells (1983) was unable to see value in movements that did not create revolutionary change. He failed to identify the changes that movements made within cities because he was constantly looking beyond the city to the larger social systems that dictate urban meaning. Castells treated the city a monolithic entity. He did not break it down into the specific elements that comprise the urban scale. Sallie A. Marston (2000) argued that the concept of geographical scales needs to move beyond the nesting of global, national and local. She advocated for the creation of a household scale, in order to account for ways in which social structures are constructed by and manifested in the daily lives of women. 
The city is more than just a container for diverse groupings of residents.

Castells wrote from the "general theoretical perspective that cities and societies are produced by the conflictual process of collective actors mobilized towards certain goals" (Castells, 1983, 319). He imagined a city produced by the complex interactions of grassroots actors, that occasionally came together to form social movements. Social movements are not organized to solely benefit their participants' social welfare; they advocate for collective goods and resources (Olsen, 1963). The immediate constituencies of movements benefit from the gains that mobilizations make regardless of whether or not they participate in protests or other movement actions.

Figure 6-1 Communities Impacted by Urban Movements

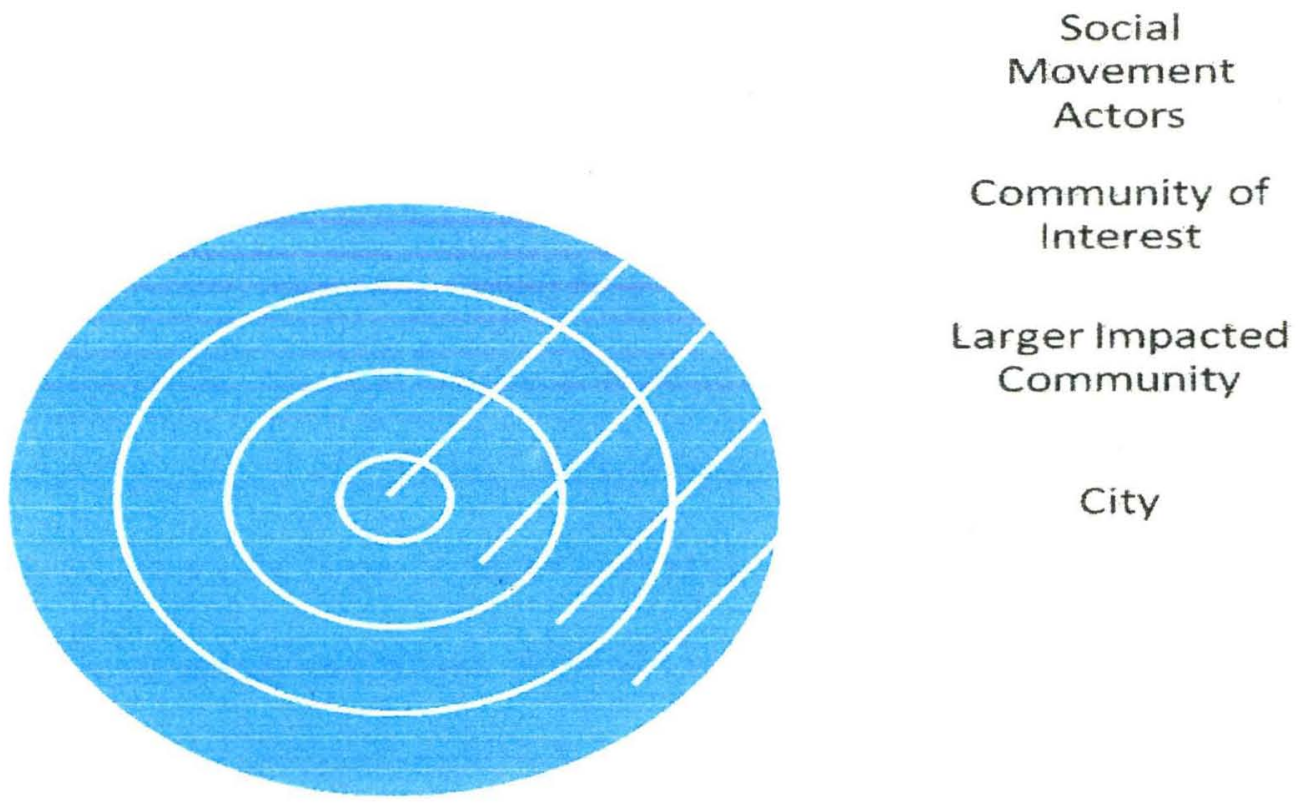


Figure 6-1 shows how urban social movements can be conceptualized as struggling for changes in concentric circles of increasingly larger communities. Protest participants are at the center of that circle. Collective identity theorists limit their study to the impacts that social movements have on this small, centralized group and its interactions with a much larger outer circle representing the established urban, national, or international-scale identities or meanings. However, in between those two circles are intervening groupings of constituents. Every social movement identifies a community of interest, which shares its values, culture or way of life (DeFillipis and North, 2004). The circle that surrounds protest participants in Figure 6-1 represents a movement's community of interest. In the case of the young campers in front of City Hall, their community of interest was homeless youth in the city of Portland. When the city agreed to consider adding shelter beds and the public became aware of the problems faced by these young people, it benefitted all homeless youth in the city, not just those who chose to camp out in front of City Hall. As the protest grew, and participants issued statements calling for a redistribution of wealth and resources, the movement had the potential to affect a larger community. In this case, the larger impacted community would have been low-income Portlanders. The third circle in Figure 6-1 shows the larger impacted community. Finally, the street kids' protest had an impact on the city as a whole. Mayoral candidates vying for votes were forced to address the issue of homelessness in Portland during their campaigns (Ellis, 1992). In Figure 6-1 the city is the outermost and largest circle. 
Breaking the city down into these nested communities allows for a more nuanced examination of how urban social movements impact the lives of city dwellers. When Castells and other urban theorists evaluated the impacts of grassroots movements, they looked only to the outer circle of the city and failed to examine its inner constituent parts (Fainstein and Fainstein, 1974; Castells, 1983; Lowe, 1986). Under that criteria, movements that seek neighborhood or community-level changes can be easily ignored or dismissed as ineffectual or parochial (Fainstein and Fainstein, 1974; Katznelson, 1981; Harvey, 1996). Conversely, when collective identity theorists focus on the smallest inner circle of movement participants, they fail to capture the basic operating dynamics of social movements (Tilly, 2004). Movements come together to try and improve conditions for their particular community of interest. Ignoring this defining aspect of movements is just as limiting as theories that set the achievement bar too high. However, collective identity theory's consideration of community construction as a fluid process does offer an important contribution to the understanding of how movements form and grow. Communities of interest are forged through struggle and they may widen or constrict as a movement evolves.

\section{Measuring Movement Impacts on Everyday Urban Life}

The concept of nested urban communities provides a template for identifying the appropriate scales by which movement impacts can be examined, but it still does not address the policy and political biases that dominate most social movement studies (Giugni, 1999). Collective identity theorists add a cultural dimension to these criteria, but it is at the expense of recognizing the political and economic resources that 
movements are able to attain (Mayer and Bartholomew, 1992). The urban social movements that took place across the Pacific Northwest during the 1990s advocated for more than just policy changes or cultural recognition; they wanted to transform the daily lives of their constituent communities. Just looking at a political, economic, or cultural piece of everyday life may not capture the potentially transformative role that social movements play. The street kids in Portland failed to win a new shelter or to repeal the anti-camping ordinance, but they believed their actions had somehow transformed the lives of their community.

Defining daily life is a difficult proposition. The social sciences take the practical route and break up the components of everyday life into distinct disciplines. Henri Lefebvre (2005b) critiqued the sociological tendency to divorce institutions like family, crime, and education from their everyday settings. He instead argued "daily life can be understood only if one considers the various activities in the totality encompassing them" (Lefebvre, 2005c, 32). Understanding everyday life in its totality is a wonderfully challenging philosophical undertaking, but it does not offer a useful means for developing precise analytical criteria that can be used to measure social movement impacts. After all, everyday life is the taken for granted activities that comprise our daily existence (Sheringham, 2006). Even thinking about everyday life as such immediately elevates these activities to a realm beyond the everyday.

Everyday life is such a broad concept. It is difficult to grasp what is meant by the everyday if it is not broken down into more digestible thematic parts. It is possible break apart everyday life without falling prey to the disciplinary fractures that 
dominate the social sciences. Rather than looking at institutions, a critique of everyday life needs to focus on the processes that construct and define our daily existence. "The production of everyday life...thus includes the production of everyday space and time as well as the objects that fill up the everyday, the mass of objects intended to fill space and time" (Lefebvre, 2005c, 134). The theorists who extended Lefebvre's critique of everyday life gravitated towards an analysis of the mass of objects that make up daily life, and the analysis of the everyday became a cultural project aimed at deconstructing popular activities and images (Roberts, 2006). Those theorists ignored the role that time and space played in determining what objects would be produced, by whom, for whom and in what manner.

Everyday time can either be cyclical or linear (Lefebvre, 2005c). Cyclical time is the natural rhythms of all living things. Day and night, sleep and activity, and seasonal changes are all examples of cyclical times that create patterns and routines in our daily lives (Lefebvre, 2005a). In contrast, linear time is created by humans and associated with the repetitive motions of labor. Nine to five, weekdays and weekends, workdays and holidays are all examples of linear time. Just as social movements fight for the supremacy of use-value over exchange-value, it is also within their purview to advocate for an elevation of cyclical time over linear time. If urban social movements are capable of transforming the daily lives of their constituencies, then the routines of these communities will be changed. There will be a measurable difference in how their linear time is structured. In the most revolutionary situations, linear time will be replaced by either cyclical time or a new temporal regime. 
Urban space structures the routines of everyday life (Lefebvre, 1991). All space is socially produced. The representation of space is the process of imagining and planning the built environment. Spatial practice is how social relationships are maintained and constructed through the bricks and mortar of the city, and representational space is the process of appropriating existing urban space in order to meet the needs of its users. Changing the way, in which urban space is imagined, produced, practiced, or used, is essential for transforming the daily lives of city dwellers. After all: "A revolution that does not produce a new space has not realized its full potential; indeed it has failed in that it has not changed life itself, but has merely changed ideological superstructures, institutions and political apparatuses" (Lefebvre, 1991, 54).

The transformation of everyday time and space may be the unspoken goals of many social movements; however activists are not limited to these two projects. As collective identity theory points out, the ultimate outcome of many protests is the formation of new identities and meanings (Melucci, 1989). The street kids that camped out in front of City Hall remained homeless; they failed to create new affordable housing opportunities. Their protests did result in expanded operating hours for the youth shelters, but no more than an hour or two in the daily lives of homeless young people was affected by that change. The real progress they made was in changing the wider community's perceptions of street kids. A new community of homeless people emerged out of that protest, and Portlanders' views of homelessness were subsequently transformed. Changing social relationships through the creation, 
expansion, or redefinition of communities is another aspect of everyday life that movements can potentially transform. When Parisians took to the barricades in May, 1968 their revolution was ultimately "incomplete, for the project specified nothing about space, the use of time and social relations" (Lefebvre, 2005c, 31). Space, time and social relations are useful guideposts for any analysis that attempts to evaluate the transformative power of social movements on daily life.

In addition to changing everyday space, time and social relations, movements have the potential to enlarge the meaning of what is possible is everyday life. Dismayed at the overall revolutionary prospects of urban social movements, Castells (1983) remained hopeful that local, grassroots action would continue to incubate the utopian dreams of future revolutions. Local social movements expand the possibilities of everyday life when they challenge the taken for granted day-to-day conditions of life in the city. Although the homeless encampment in Portland was too brief for its participants to have to worry about managing their daily activities, such protests often spark new forms of everyday living and relating to one another for their participants (Wagner, 1993). In addition to the mini-utopias that are formed by protesters, collective action challenges the notions of the everyday by sharing its critiques of daily life with the wider community. The act of critiquing everyday life exposes its underpinnings and suggests new ways of living. The possibility of producing alternative forms of everyday time, space, and social relations may not be realized by a particular social movement, but part of its legacy might be the implementation of such a possibility in a different time or place. 
The impacts of urban social movements can be measured in the transformation of everyday time, space, social relations and the possibilities of city life. These criteria will be used to evaluate the impacts that the five case study movements had on the daily lives of their communities of interest in Portland and Seattle during the 1990s. Each case study represents one of the five areas of everyday life that protesters contested in the Pacific Northwest. The Hotel Workers' Organizing Committee/Workers' Organizing Committee challenged everyday labor relations in Portland. The Black United Front's school boycott contested the provision of collective consumption services in the city. Central District residents organized against the imposition of the Weed and Seed program in their Seattle neighborhood. Operation Homestead squatted abandoned buildings to protest Seattle's downtown housing crisis. The young women who challenged the Rose Festival princess competition at a Portland high school sought to change the way the city imagined its female citizens. Chapter Seven tells the stories of these urban social movements. Chapter Eight will use the criteria developed in this section to evaluate how these movements transformed the everyday lives of their community of interest. 


\section{CHAPTER SEVEN \\ STORIES OF PROTEST IN THE PACIFIC NORTHWEST \\ FIVE URBAN MOVEMENTS FROM THE 1990s}

\section{Urban Labor Movements:}

The Hotel Workers' Organizing Committee/Workers' Organizing Committee

Late one evening in 1993, 60 cooks and housekeepers from across the city of Portland ratified a Hotel Workers' Bill of Rights (Hill, 1993). A majority of those workers earned less than $\$ 9,000$ a year, many had no health insurance, and $47 \%$ were denied legally-mandated rest breaks during their shifts. Sixty-three percent of hotel workers were non-white and most were women. Whenever workers had tried to organize, their shifts and hours were cut in retaliation. The Hotel Workers' Bill of Rights was designed to be the first step towards forcing the hospitality industry to treat its workers more fairly (P. Cervantes-Gautschi, personal communication, January 24, 2008).

In the 1980s, the hotel workers' union in Portland was over 10,000 strong (P. Cervantes-Gautschi, personal communication, January 24, 2008). By 1991, less than 2,000 hotel workers in Portland were unionized. This steep decline in union membership was partially due to the consolidation of the hotel industry and its aggressive anti-union campaign. However, the unions had also failed to confront these changes with major organizing drives. As a result, the union local no longer reflected the hotel workforce. By 1991, the typical hotel worker was a recent immigrant from Asia, Latin America, or Africa, but all of the union leaders were white and monolingual. "There were very intense communication barriers and attitude 
barriers" between the union and the hotel workforce (P. Cervantes-Gautschi, personal communication, January 24,2008 ). The national union called in a seasoned organizer to fight upcoming decertification battles.

When Peter Cervantes-Gautschi arrived with his family in Portland they "went into shock....we had no idea that there was such intense racism west of the Rocky Mountains" (personal communication, January 24, 2008). He agreed to help organize hotel workers, but would only do so through a committee that could remain autonomous from the local union. The Hotel Workers Organizing Committee (HWOC) was created in 1991. From its inception, the organization not only had to overcome problems in the industry, but it also had to confront the racism that permeated the workplace, the union, and the city. A team of three young organizers, who had similar cultural backgrounds as the hotel workforce, were brought in to help build the HWOC and eventually increase union density in the industry.

HWOC organizers had to deal with "a huge amount of fear those first few years" (P. Cervantes-Gautschi, personal communication, January 24, 2008). Many immigrant workers were afraid to get involved in politics, especially if they were refugees or had lived under a repressive regimes. The hotel industry divided the workforce by race and ethnicity. This divide and conquer strategy was so blatant that in the Hitlon Hotel, housekeepers were assigned to floors according to their ethnicity. Chinese women cleaned one floor, while Vietnamese or Filipinas cleaned others (Cervantes-Gautschi, 2007). The hotel paid an "inspectress" a few cents more an hour to supervise each floor. The inspectresses were always from a different ethnic 
background than the workers they supervised. Filipinas checked the work of Chinese and Vietnamese women, while African-American women were hired to inspect the Filipinas' work. To deal with this ethnic divide, the HWOC initially organized separate house meetings for each community of workers. Once the organizers built sufficient trust among a group of workers they began to hold integrated meetings. At the first such meeting, two Vietnamese workers tried to hide when they saw a Filipina worker, assuming she was on the side of management.

As the HWOC began to develop relationships of trust among the workers, the organization started to take action. The Hotel Workers' Bill of Rights was passed, petitions demanding an end to the public subsidy of anti-union hotels were circulated, and the organization fought decertification battles (Kajihiro, 1994). The HWOC grew, and they began to work on statewide campaigns (P. Cervantes-Gautschi, personal communication, January 24,2008 ). As one of the strongest labor organizations in the hospitality industry, HWOC led two consecutive legislative campaigns to defeat a bill that denied the minimum wage to tipped workers. When the Oregon Health Plan passed, many eligible HWOC members could not apply for this state-subsidized health insurance because the forms were written in bureaucratic English. The HWOC translated the application into seven different languages, and their translations were eventually adopted by the statewide agency that administered the plan.

This ongoing organizing led to the creation and development of a dynamic group of rank and file leaders. In 1994, a Red Lion hotel worker named Jeri Williams injured her back after cleaning twenty-two rooms in an eight-hour shift (J. Williams, 
personal communication, February 5, 2008). She was put on light duty and assigned a company doctor. Six months later, she was still in severe pain, unable to work, afraid of losing her job, and falling into a deep depression. Williams met an organizer from the HWOC who helped her get a workers' compensation attorney. The HWOC supported her through the workers' compensation process, helped her find appropriate medical care, and defended her from company harassment. The HWOC "cared about me," remembers Williams, "they were telling me I had rights, and I never believed I had rights" (personal communication, February 5, 2008).

Soon Williams was working as an organizer for HWOC. She led an anti-toxics campaign at the Red Lion Hotel. Housekeepers were getting sick with respiratory illness and skin rashes after using a new cleaner that contained the chemical glycol. When their workplace organizing failed to get results, the women ran a public campaign to draw attention to their plight. Seattle billionaire Paul Allen held title to the land the Red Lion hotel was built on, so fifty hotel workers occupied his office, demanding he pressure the management to stop the using glycol (Sundvall, 1996). Even with the support they eventually won from Paul Allen, the Red Lion still refused to eliminate this cleaning product, although they did provide the workers with gloves, masks and other protective gear to wear while using the toxic cleaner. The anti-toxics campaign also sued the Sheraton Hotel, which routinely hired workers to remove asbestos without proper training or protection (Bernard, 1997).

The anti-toxics drive was one of three campaigns that the HWOC continued to lead after its withdrawal from the hotel industry. In 1995, the HWOC stopped 
organizing in hotels, because the new leadership in local union began to resent their presence (P. Cervantes-Gautschi, personal communication, January 24, 2008). Rather than jeopardize the gains that had they made, the organization voted to change its name to the Workers' Organizing Committee (WOC) and to expand its mission to all low-wage, immigrant workers. The WOC continued to run the Red Lion anti-toxics campaign and launched an organizing drive among day-laborers. Some of WOC's constituents worked as day-laborers before they found permanent jobs in the restaurants, garment factories, or packing-houses.

Day-laborers gather on the corners of most major cities to look for informal, temporary work. In Portland day-laborers are mostly Latino immigrants, and they gathered near Northeast Grand and Burnside early weekday mornings in hopes of finding a job. Day-laborers faced exploitation by their employers, harassment from the authorities, as well as dangers from traffic and crime in the neighborhood (Day Laborers' Program, 1997). In 1997, WOC lobbied for a city-funded day-laborer center that would replace the corner job site where men gathered to search for work. After a year of meetings with a hostile local business community, the city withdrew its support for the proposal claiming they "had not been able to reach the critical mass of stakeholder involvement necessary to reach consensus" (Sten, 1998, 1). The city no longer believed the "time was ripe" for a workers' center and it would be ten years before the council finally passed the proposal to fund a day-labor center (Sten, 1998, 1; Maushard, 2007). 
In addition to the fight for a city-funded workers' center, WOC launched a program to protect day-laborers from immigration raids. In response to the workers' center proposal, local business owners initiated a campaign of retaliation against the day-laborers. Businesses called the INS demanding enforcement of immigration law on the corner (Tongue, 1997). The INS typically raided the day-laborer sites once each summer, but as the business owners began to complain, immigration stepped up their sweeps. Two raids occurred in May 1997, resulting in 23 arrests and by July, 50 workers were facing deportation hearings (Snell and Anderson, 1997). In response, WOC organized Migra Watch, to photograph and record INS agents' activities (J. Williams, personal communication, February 5, 2008). WOC provided legal assistance and mobilized community pressure to stop the repressive and illegal tactics used in the sweeps. The publicity generated by Migra Watch activists and the relationships that WOC built with its community partners during this campaign eventually resulted in a moratorium on INS sweeps and the resignation of INS District Director David Beebe (Jacklett, 1998; Read and Sullivan, 2000).

The Migra Watch program was just one of the public campaigns that the Workers' Organizing Committee launched in the mid-1990s. In 1996, the committee developed a Workers' Bill of Rights, which was similar to the earlier document the hotel employees had drafted (Cervantes-Gautschi, 2005). "It was essentially a pact...that began to address what we all should have" (P. Cervantes-Gautschi, personal communication, January 24, 2008). The Workers' Bill of Rights was passed by the city's Metropolitan Human Rights Commission (MHRC). WOC planned to 
use the commission's endorsement to push for binding city and county-wide living wage and workers' rights ordinances. Immediately after the passage of the Workers' Bill of Rights, the City Council voted to abolish the MHRC. "We took it very personally because we had passed the Workers' Bill of Rights and we fully intended on pushing for things...we were at the action part and now they removed the vehicle" (J. Williams, personal communication, February 5, 2008).

The WOC campaigns continued into the next decade. They were part of a coalition of labor organizations that pushed for a fair wage ordinance for all city subsidized employees, and they proceeded to lead an organizing drive for downtown parking lot attendants who were not receiving that fair wage (J. Williams, personal communication, February 5, 2008). The day-laborer campaign launched a new organization called VOZ (Voice), the Educational Project for Worker Justice (Jacklett, 1998). VOZ continues to advocate for workers' rights and provides social services and popular education opportunities for immigrant laborers (Maushard, 2007). The anti-toxics campaign expanded its focus to work on neighborhood-based environmental justice issues (J. Williams, personal communication, February 5, 2008).

Like other urban labor protesters in Portland, the HWOC/WOC fought to raise the wages, improve working conditions, and to ensure that all residents were guaranteed the right to earn a living. In the process, they built a new community of low-wage immigrant workers in Portland. This community broadened the scope of labor issues in Portland by forcing the city to take a stand for workers' rights. A decade after the initial negotiations broke down, the WOC finally won city funding for 
construction of a day-laborers' center (Maushard, 2007). This space has the potential to transform the day-laborers' daily routines by offering them a safe, well-organized, and closely monitored way to connect with prospective employers. In addition to these changes in the ways that day-laborers spend their time, WOC helped relieve some of the stress that Red Lion housekeepers felt during work and at home through the anti-toxics campaign. Despite losing the fight to eliminate glycol, WOC did manage to get protective gear for the housekeepers to prevent the levels of exposure that led to chronic illnesses.

\section{Collective Consumption Movement:} The Black United Front's Boycott of Portland Public Schools

During the 1970s, Portland Public Schools promoted an aggressive, one-way desegregation policy. Black students were bused out of their neighborhoods and dispersed throughout the district, while white students remained free to attend their local schools. The results were devastating for black children and families. It was not unusual for parents to have to drive to as many as three different schools to pick up their children (R. Herndon, personal communication, March 12, 2008). Black students were isolated from their peers and often targeted by white administrators, teachers, and pupils. In 1980, the Black United Front (BUF) organized a one-day boycott of Portland Public Schools to protest the forced busing of black children (Graves, 1990). Three-quarters of black students participated in the boycott and forced busing was halted. One year later, the BUF led another successful boycott to win construction of 
a new middle school in the Albina neighborhood, an area which had no building to serve fifth through eighth graders.

By the 1990s, the movement was focused on issues of educational equity. "In spite of the changes made as a result of earlier boycotts and the agreements we had made with the school board, there had still not been an appreciable amount of progress for black students' academic performance" (R. Herndon, personal communication, March 12, 2008). To address this achievement gap, the BUF brought together a coalition of community groups and wrote up a proposal to improve the quality of education for black students. The BUF "was an ongoing movement that built on its past experiences and tried to take advantage of the latest educational research" (R. Herndon, personal communication, March 12, 2008). That research, as well as experiences both from within and outside of the community, helped guide the drafting of the 12-Point Educational Improvement Action Plan (Educational Improvement Action Plan, 1990). The plan called for greater community control of schools, more accountability from teachers and administrators for student progress, adhering to timelines for meeting student achievement goals, and for strategic and long-term planning to be based on sound educational research and best practices from other places. The community sent its proposal to the board and waited for a response.

The BUF waited for over a year, and when the district offered no response, they called for another boycott. The Front declared: "We will no longer allow black children to be sacrificed on the altar of Portland School Board complacency" (Graves, 1990 , B1). Only $50 \%$ of black students could read or do math at grade level, while 
close to $80 \%$ of white students met that standard. The BUF declared: "Poor kids get a second class education in Portland" (Mazza, 1990, 1). The school district claimed it was already addressing the minority achievement gap, and black parents needed to do more to support their children's education ("Black United Front Calls for Boycott," 1990). Ron Herndon, chair of the BUF responded: "When the system didn't work for middle-class white kids they didn't blame middle-class white families and say, you're not spending enough time with your children" ("Black United Front Calls for Boycott," 1990, 1).

The BUF held community meetings to publicize the boycott, and the Rainbow Coalition went door-to-door distributing over 3,000 leaflets to parents ("Black United Front Plans School Walk-Out," 1991; "Boycott Backers Canvas Neighborhood," 1991). At the first monthly school board meeting in 1991, protesters picketed outside calling for the board to "adopt the plan" and "listen to the parents" ("Demonstators Parade School Boars," 1991, 1). In the weeks leading up to the boycott date, the board desperately tried to avert the action. They called for negotiations then refused to bargain about the proposed plan. After multiple meetings and attempts to negotiate, Herndon was frustrated. "I've never been so misled in all my life...never...if you can't work it out with two ministers, I don't know who they're [Portland School Board] going to work it out with" ("Black United Front Blasts School Board," 1991, 1). In a last ditch attempt to stop the boycott, the school board appointed a nineteenmember task force to study the achievement gap ("Task Force to Study School 
Quality,"1991). Thirteen of the task force members were school district employees and parents and community were once again shut out of the process.

In preparation for the boycott, organizers arranged eight sites where students could attend alternative classes to learn about social change movements and the history of boycotts and direct action ("Alternative Classes Set Up," 1991). On February 4,1991 , thousands of students stayed home, $55 \%$ of students at the predominately black Jefferson High School joined the boycott as did 330 from King Elementary ("Boycott of Portland Public Schools," 1991). Even 60 students from overwhelmingly white Wilson High School supported the boycott. BUF spokespeople declared the boycott "very successful" and vowed to demonstrate and sit-in if the board still refused to consider the plan ("Interview with Ron Herndon," 1991, 2). It was "very clear that parents wanted change," and students agreed. "I'm tired of seeing my sisters and brothers struggling through their classes, and at the same time, teachers passing kids just so that they can meet the requirement for sports" ("Students Discuss Boycott,"1991, 3).

A few weeks later, the BUF and school board agreed to set up a task-force charged with creating a plan for improving student achievement (Graves et al., 1991). The committee would be led by former Chief Justice of the Oregon Supreme Court, Arno Denecke, and the board promised to take action on the task force's recommendations by the end of the school year. The committee's final report echoed the call for many of the same reforms outlined in the 12-Point Educational Improvement Action Plan and set a timetable for implementing site-specific 
improvements (Special Task Force of Educational Improvements, 1991). Even with the stamp of endorsement from "an objective third party," the board still "didn't take these recommendations seriously" ( $R$. Herndon, personal communication, March 12, 2008). In 1993, the board finally set-up site councils to oversee curriculum and administrative decisions at each school, but these councils were, once again, dominated by teachers and district employees. Throughout this time, Oregon schools were facing a major funding crisis. "They want parents to go down and beg for them in Salem when they need more money, but when it's time to make some decisions, it's no, we're the professionals" (Foy, 1993, 1). Meanwhile test scores for black and lowincome students continued to plummet.

By the 1996/97 school year, a new board was elected and superintendent Matthew Prophet left the Portland school district (R. Herndon, personal communication, March 12, 2008). The BUF met with the new board members, before they took office, and asked them to commit to taking action to improve the quality of education for low-income and minority students. The school board set up the Community Monitoring Advisory Coalition (CMAC) to help guide the district through the improvement process (Portland Public School Board Regular Meeting Minutes, September 12, 1996). The CMAC was a multiracial committee with representatives from the African-American, Latino, Southeast Asian and Native American communities. The coalition desired a school district where "everyone achieves, no exceptions, no excuses," and they laid out a detailed plan that would help the board meet this goal (Community Monitoring Advisory Committee, 1997, 1). The board 
"accepted their recommendations but then did not act" and by the end of the year the CMAC and other community organizations were calling for another boycott (R. Herndon, personal communication, March 12, 2008).

The threat of another boycott pushed the district into considering serious action. Community pressure from the new coalition, pickets and parent testimony at board meetings forced the board to stop hiding behind its same old excuses for inaction. They could no longer blame the achievement gap on single parent households or low-income families. One parent testified, "It was akin to folks throwing rocks and then hiding their heads in the sand" (Portland Public School Board Regular Meeting Minutes, September 12, 1996). In May, the board approved a resolution that would place the lowest achieving schools under strict review (Di Rado, 1997). Finally, in June 1997, the school board announced plans to reconstitute Humboldt Elementary School (Portland Public School Board Regular Meeting Minutes, June 26, 1997).

Humboldt Elementary was the lowest performing school in the district, $98 \%$ of third-grade students failed to meet basic math standards (Hewitt, 1997). The board announced an ambitious plan that would fire all of the elementary school's staff and rehire only those who had a solid record of improving student achievement. The school would be completely redesigned over the summer break using findings from the latest educational research and examples of best practices in other districts (Di Rado and Carter, 1997). The board finally agreed they could no longer "afford to wait," and this action validated longtime educational equity activists' claims that the 
achievement gap was a "crisis situation" (Di Rado and Carter, 1997, A1). A few weeks later, the board announced plans to reconstitute Jefferson High School at the end of the following school year (Graves et al,, 1997).

The Humboldt reconstitution was a "very successful and most complete effort" (R. Herndon, personal communication, March 12, 2008). Unfortunately the redesign of Jefferson was not so effective. "The high school level was much more difficult. Students have so much failure in their lives, eight or nine years of failure, and then you have to try and make a difference when they are young adults" (R. Herndon, personal communication, March 12, 2008). The community coalition took responsibility for its success and failures. "We were batting $.500 \ldots$ still it was better than the district and we didn't try and run away from that" (R. Herndon, personal communication, March 12, 2008). An interim superintendent led the radical school overhaul. Once a permanent school chief was hired, educational equity activists immediately shifted back to their community organizing tactics. "Here we were, getting a new superintendent that had never been a leader anywhere where he had children performing at or above grade level. Something had to be done for the sake of our children" (R. Herndon, personal communication, March 12, 2008).

That something was a new, multicultural initiative known as the Education Crisis Team. The Crisis Team was founded in June, 1999 with the aim of bringing parents and community members into the schools. Crisis Team members held schools accountable and helped to promote student achievement. "This was not an adversarial effort" ("Crisis Teams," 1999). It was designed to be a grassroots support and 
monitoring network that would work in partnerships with local schools. The five to seven member teams started monthly meetings with principals in September, 1999 (Parker, 1999). The Education Crisis Team continued to work in the schools until 2003. They also kept pressure on the board organizing marches, rallies, and when necessary, disrupting meetings (Nkrumah, 2006).

The Black United Front created a new sense of possibility for minority students and parents. They demanded that schools serve the needs of all students. The BUF fought for a multicultural curriculum and called for community-control over neighborhood schools. By eliminating the forced busing program, the BUF consolidated a critical mass of black students in their neighborhood schools. This allowed parents and community members to focus their energies on improving educational opportunities in those schools. It also freed up parents from having to commute to far-flung neighborhoods to transport their children to school, making it easier to get involved in school issues.

\section{Neighborhood Movement:}

\section{The Central District Coalition against Weed and Seed}

In April 1992, the city of Seattle was awarded a $\$ 10$ million Justice

Department grant to implement the Weed and Seed program in its Central District neighborhood (Holloway, 1992a). Weed and Seed was a federal policing program that tried to "weed out" crime in targeted neighborhoods through saturation policing and to "seed" in more desirable elements by funding social service programs. Neighborhood residents in the Central District, a traditionally black community, had never heard of 
this new Justice Department program, until a Request for Proposals was issued to local social services agencies for the "seed" portion of the grant money. Mothers Against Police Harassment (MAPH), a Central Area community group that organized around police accountability issues, got a copy of the executive summary of the grant application but could not find out specifics about the program. What they discovered from the summary alarmed MAPH activists so much, they organized a coalition of community groups "to fight the local police state in the Central Area" (Holloway, 1992a, 1).

At a community meeting, MAPH and other residents raised their concerns about the specter of federal agents patrolling their streets ("Emergency Meeting," 1992). Black youth were already targets of police surveillance and profiling. The community was concerned that under this new program, youth could be arrested and charged by federal police, and agents would sweep the neighborhood or set up boot camps. They questioned why the Central Area was targeted for this type of heavyhanded policing. "It means suspension of black people's civil rights in the target area, which is defined by those with high dropout rates and people on public assistance, that's how they define the target area" ("Emergency Meeting," 1992, 1).

One week later Mayor Norm Rice outlined the details of his newly renamed "Operation Care" proposal to seven hundred Central District residents (Lawson, 1992, 1). The mayor admitted to the crowd, "Yes, we made mistakes, but this is not any covert clandestine act to put this area under martial law or a license to create genocide in our community" (Lawson, 1992, 1). Residents remained angry and adamantly 
opposed to the proposal. Young people in the community already felt targeted by the police. Neighborhood residents had long told stories about a black tinted- windowed police van that would drive by and take photos of local youths. One meeting attendee showed the photos he had taken of the van, and the police chief had to admit that it was a department vehicle. By the end of the night, little was resolved. Mayor Rice agreed to set up a 40 member panel of neighborhood residents to suggest changes to the program proposal.

Mothers Against Police Harassment and other coalition members were not only concerned about the saturation policing and heavy-handed tactics associated with Weed and Seed, they also saw the program as a tool of gentrification in the Central Area. "The area of Seattle that Weed and Seed is targeting is the traditional AfricanAmerican community, which is in the process of gentrification" (Mothers Against Police Harassment, 1992, 2). The gentrification pressures led the coalition to demand the elimination of block watches, which were dominated by wealthier, white newcomers, from the neighborhood advisory committee (Holloway, 1992b). Central District residents also called for local oversight through this community advisory group of all federal policies that were implemented under the auspices of the Weed and Seed program. The mayor would chair the advisory committee and neighborhood residents, individuals and representative groups would make up half of its members.

The aspect of the proposal that drew the most ire from activists was the plan to "federalize" the Central Area (Mothers Against Police Harassment, 1992, 2). The proposal allowed street sweeps by federal agents and the use of "army occupation 
methods" in the neighborhood. This was the "weed" portion of the program, and it accounted for $80 \%$ of the grant funding ("Weed and Seed Fact Sheet," 1992). The program was designed to weed out "undesirables" to make the neighborhood fertile for a reseeding (Holloway, 1992b). The "seed" portion of the grant would go to partner agencies, like the school district and the housing authority, and these participants would be required to share information about their clients with local and federal police (Lawson, 1992,1). Area residents won a big victory when Seattle Public Schools announced they withdraw their application for funding through the Weed and Seed program.

The issues of police harassment and Weed and Seed dominated most the community events in the Central Area during 1992. In May, Seattle erupted into two days of rioting after the Rodney King verdict, forcing the city to face-up to its problems with racism and police brutality (Angelos et al., 1992). A post-riot Rap on Racism drew Central Area young people who spoke out against Weed and Seed (Douglass, 1992). Meanwhile, the coalition opposing Weed and Seed continued to grow. Diverse groups joined in, some concerned with civil liberties, others opposed to the targeting of blacks and the poor, some angered by the lack of citizen participation and even pacifists who worried about the escalation of violence in the city (Marshall, 1992). The coalition organized protests and speak-outs to oppose the proposal while Rice's community advisory group negotiated changes that would make the proposal acceptable (Lilly, 1992, Merritt, 1992; "Federal Grant," 1992; Norton and Birkland, 1992). 
The revised Weed and Seed proposal contained many of the elements that community groups sought. Instead of $80 \%$ of the funds going towards "weed" activities, now the grant was divided with $47 \%$ funding "weed" and $53 \%$ going to "seed" programs ("Weed and Seed Fact Sheet," 1992). Social service organizations receiving "seed" money no longer had to share client information with the police. The revised proposal dropped the plan for neighborhood sweeps and gave local authorities control and veto power over all federal involvement in the Central Area. In addition, a steering committee made up of neighborhood residents, including youth, would make decisions about the allocation of the seed grant money (Resolution $\# 28654,1992$ ). Finally, the city attorney would decide how offenders arrested under the program could be charged, eliminating the threat of federal, mandatory minimum sentences. The City Council scheduled a vote on the revised proposal for December 15, 1992.

Despite these revisions, the community coalition still hoped to halt the city's acceptance of the Weed and Seed grant money. Mothers Against Police Harassment and other coalition members urged their supporters to put pressure on the city council. The night of the vote, the community picketed outside council chambers and packed the hearing room (Merritt, 1992). The city council voted 6-3 to accept the revised Weed and Seed program, leaving activists disappointed (Resolution $\# 28654,1992$ ). Although the revised proposal made definite improvements; it "included little attention to drug rehabilitation or the creation of new jobs" (Merritt, 1992, B1). After the passage of Weed and Seed, community groups like Mothers Against Police Harassment returned to their watchdog role (Merritt, 1992). The resident- 
dominated Weed and Seed Advisory committee allocated grant money to youth programs that provided job training, after school activities, and health care for young Central District residents (Njubi, 1993). Ongoing community pressure reshaped activities under the "weed" portion of the program. In the first year of program, the Seattle police focused on "high visibility community contact," which meant officers attended neighborhood meetings and set up foot patrols ("Seattle Police Memo," 1994, 1). Community members remained vigilant about the Weed and Seed program, and within one year, some major changes in policing strategy occurred (Santana, 1998). “At first we strictly did enforcement, making arrests. We didn't' think about prevention. We thought we needed to make a bunch of arrests" (Santana, 1998, 1). In 1994, the police carried out their first "reverse sting" where drug buyers were arrested instead of drug sellers (Valvadere, 1994, 1). Of the 23 arrestees caught in the sting, 20 lived outside of the Central Area. Four more reverse sweeps occurred, and the tactic was also used to arrest johns in prostitution stings ("Seattle Police Memo," 1994).

Mothers Against Police Harassment and other community groups kept the pressure on to provide more civilian oversight of the police. Community members served on city advisory groups and continued to organize protests and speak-outs to protest racial profiling and to fight for a civilian review board (Police/Community Relations Task Force, 1994; Resolution 30223, 2000). Many former coalition members pressured the Seattle City Council to review police conduct during the WTO protests, which led to significant changes in tactics and more oversight (Public Safety and Technical Advisory Committee, 2000). Activists continue to staff a police abuse 
hotline that keeps track of and publicizes incidents of police brutality as well as supports victims in the complaint process $(\mathrm{H}$. Walden, personal communication, April $7,2008)$.

Mothers Against Police Harassment made community-control of the police a real possibility for Central District neighbors. They also cemented African-Americans claims to the rapidly gentrifying Central Area. Even through the coalition won significant changes to the original Weed and Seed grant proposal, they ultimately failed to prevent the gentrification of the neighborhood. Many of the youth that benefitted from the community programs the revised program funded, were displaced from the neighborhood.

\section{Urban Space Movement: Operation Homestead}

On New Year's Day in 1988, a group of housing activists took over the abandoned Gatewood Hotel, a single-room occupancy building that had been empty for three years (Hatch, 1989). A few years before, the city filed suit against the owner, Sam Israel, for illegally shutting the building down, but it still remained empty. The occupation of the hotel provided the push needed to force Israel into leasing the site to a non-profit housing developer (Glover, 1990; Godes, 1991). The 91-unit building was eventually renovated and turned into affordable housing.

Buildings like the Gatewood Hotel were quickly disappearing from downtown Seattle. The city was once a haven for low-income itinerant workers, and its downtown was full of single-room occupancy hotels. But this form of housing was 
fast becoming a relic in the city's core. From 1960-1990, downtown Seattle lost more than 20,000 units of affordable housing (Martin, 1990). From 1983 to 1989, 1,500 affordable units disappeared (Broom and Hatch, 1989). During the 1980s and 1990s, homelessness skyrocketed, and on any given night, there were at least 3,000 people sleeping on the streets of downtown Seattle.

The Gateway occupation was initiated by a group of young anarchists who had moved to Seattle from the east coast (J. Fox, personal communication, April 4, 2008). They were living in "quiet squats" in single-family abandoned houses in the Central Area. These young activists revitalized Seattle's housing movement. In the 1970 s, the city was home to a very active and progressive tenants' rights movement that succeeded in putting a rent-control ordinance on the local ballot. The movement declined during the 1980 s, as many activists left to work on other issues, often in the peace and justice movement. The remaining organizations worked to preserve the diminishing downtown housing stock using lawsuits, public policy, land use interventions, and occasionally, protest. The bold, widely-covered, and instantly successful action at the Gatewood Hotel "rejuvenated" the fledgling housing movement (J. Fox, personal communication, April 4, 2008).

Eighteen months after the takeover of the Gatewood Hotel, a week-long series of events was held to protest the demolition of the state-owned McKay Apartments, a 73-unit SRO building ("Focusing on Plight of Homeless," 1989). Washington State purchased the McKay Apartments as part of its Convention Center construction project. The empty building was scheduled for demolition and conversion into a 
temporary parking lot (Broom and Hatch, 1989). A group called Operation Homestead sponsored the week of protest events. Activists camped out in front of the building for four consecutive nights, and on the fifth night, occupied the apartment complex. The police arrived within hours and arrested ten demonstrators.

Although the occupation was short-lived, the fight over the McKay Apartments lasted for months. Operation Homestead activists kept vigil in front of the building for two months, and protesters took their grievances to the Convention Center's board and the city ("Activists End Vigil at Deserted Building," 1989; Angelos, 1989; Lilly, 1989). Protesters forced a hearing before the city examiner to determine whether or not the state had violated a Seattle law aimed at curbing abandonment. The dispute ended when the Convention Center's board agreed to spend $\$ 750,000$ to help renovate the Oregon Hotel, an 81-unit affordable housing complex located a few blocks away (Lilly, 1989). In return, the state would be allowed to demolish the McKay Apartments.

This partial victory was "very sad" for many activists who felt the building was being torn down "for no reason except that conventioneers don't want to walk past a class of people other than their own" (Plank, 1990a, Bl). When the wrecking ball hit the McKay in 1990, two die-hard activists ended their months-long vigil on the steps of the building. In spite of the loss of this building, housing activists learned an important lesson. "Only when we took direct action did something start to happen at the McKay" (Plank, 1990a, B1). They vowed to keep on occupying vacant buildings. 
"You can blow out the candle but you can't stop the fire, we've started something here. We need to keep working together to get more victories" (Plank, 1990a, B1).

In 1991, Operation Homestead again hung its banners outside of a vacant building. Hand lettered sheets declaring "Home Sweet Home," "We Reclaim," and "It's Alive," were displayed in the windows of the thirty-four unit Arion Court (Brown, 1991c, C1). By this time, only 5,800 units of low-income housing were left in downtown Seattle, and 500-units in the immediate blocks surrounding the Arion Court had recently been destroyed. The city had an anti-abandonment law, but they failed to enforce it. Two dozen activists moved into the empty units at the Arion Court. Previous occupations lasted a few hours, but this time, the police did not immediately arrive (Haberstroh, 1991). Operation Homestead squatters began to clean-up the building and opened its doors to the homeless. When the police arrived four days later, many of the squatters were homeless people. "For half of them this really was their home" (Taylor, 1991, C1). Homeless and housed activists cooperated with the eviction process, until one activist fell through a third-floor fire escape and was rushed to the hospital for her injuries. A crowd of 50 supporters became angry and many stayed across the street until all eleven arrestees arrived safely back at the hotel.

During the occupation, Operation Homestead activists negotiated with the owners of the Arion Court ("Housing Protesters Meet with Owners," 1991). A few weeks later, the owners agreed to donate the building for use as a homeless shelter or low-income housing (Haberstroh, 1991). A planned rally and march to the site turned 
into a victory celebration. Operation Homestead activists not only celebrated the addition of over thirty new units of affordable housing to the city's stock, they also won an agreement to ensure that the Arion Court would become a tenant self-managed complex. Process was as important as outcome to many activists in Operation Homestead. The group functioned on the basis of consensus and democratic decisionmaking, almost to the point of tedium (J. Fox, personal communication, April 4, 2008). The Arion Court became one of a number of self-managed properties administered by the local, non-profit Low Income Housing Institute.

The Pacific Hotel was the fourth building that Operation Homestead took over in just four years (Angelos, 1992). The Pacific Hotel is a 106-unit building located in the central downtown area. It was repossessed from its owner by Seafirst Bank and lay vacant when Operation Homestead moved in. The activists served a free breakfast in a downtown park and then marched to the hotel. Within minutes, the building was opened and signs reading "Homes for Humans" hung from the windows (Shatzkin, 1992, B4). This time, the majority of the squatters were homeless people. The squatters gathered in the building's inner courtyard, singing and playing guitars while a negotiating committee went to meet with Seafirst Bank officials. The occupation lasted six days, and over 200 homeless people stayed in the building while it was opened (Angelos, 1992).

The bank claimed it was already considering selling the Pacific Hotel to a nonprofit developer when Operation Homestead occupied it (Angelos, 1992). The bank refused to negotiate with non-profit Plymouth Housing while the building was 
occupied. After six days, the squatters were evicted. Operation Homestead activists "kept the pressure on" Seafirst Bank after the occupation ended, protesting at their downtown headquarters and leafleting the home of the bank president (Birkland, 1992, B4). Almost nine months after the last squatter rolled up their sleeping bag from the floor of the Pacific Hotel, the bank agreed to sell the building to Plymouth Housing. Operation Homestead activists were "glad that Seafirst was being responsive to the community needs" but dismayed that "the building was abandoned all winter long while there were approximately 4,000 people living on the streets" (Birkland, 1992, B4). This occupation proved that direct action not only achieved long-term affordable housing goals, but it could also meet the immediate needs of homeless people.

In 1995, activists staged two short-term protests to try and open up more housing. The first action, at a building on Seventh Avenue and Pine Street, lasted for a few hours, but the handful of squatters left once the police arrived (Haines, 1995). Their target was the vacant apartments located over occupied ground floor shops. These upper apartments were in severe disrepair. The second occupation occurred at the Payne Hotel, another building slated for demolition (Bjorhaus, 1995). The SWAT team broke down the door of the building with their guns drawn and sprayed water hoses on the two Operation Homestead activists. The city claimed the rough police treatment was justified, because they needed to protect the squatters from asbestos danger in the building. These last two occupations did not lead to the creation of any more low-income housing. Where the Seventh and Pine building once stood, a luxury hotel was built and the Payne became Planet Hollywood and Niketown (J. Fox, 
personal communication, April 4, 2008; Bjorhaus, 1995). By the mid-1990s, many of the activists who inspired Operation Homestead had left town or moved on to other projects. The movement was waning.

Meanwhile, other direct action initiatives sprung up around town. SHARE (Seattle Housing and Resource Efforts) organized a series of tent cities (J. Fox, personal communication, April 4,2008). SHARE was an advocacy group run by and for the homeless. Homeless women also came together in the late 1990s to support one another and fight for access to safe shelter. They founded an organization called WHEEL (Women's Housing, Equality and Enhancement League). Homeless youth, who lived in the Capitol Hill and University District neighborhoods, organized street marches to protest police harassment and opened up "quiet squats" (J. Fox, personal communication, April 4,2008). A group of youth activists, inspired by the work of Operation Homestead and supported by the Seattle Displacement Coalition, created a self-managed youth shelter that continues to exist today.

Building occupations ceased after the Payne Hotel, but the effort to create more low-income housing did not end with the demise of Operation Homestead. In November 1995, a \$50 million affordable housing construction levy was placed on the ballot (Beason, 1992). Launching the campaign to support this levy were the residents of the newly opened Arion Court. The tenants painted a mural in support of the levy on the side of their newly renovated home.

Operation Homestead established low-income people's right to occupy downtown Seattle. They built a community of homeless and housed activists who 
reclaimed buildings from the hands of real estate speculators and turned them into homes for the poor. More than 300 units of low-income housing were established as a direct result of Operation Homestead's occupations. These 300 units became part of a permanent stock of low-income housing that allows the poor to remain active participants in downtown life.

\section{Imagination Movement:}

\section{The Rose Festival Pageant Protests}

Nearly a month before the actual event, the city of Portland begins gearing up for its century-old celebration known as the Rose Festival (Sullivan, 1994). Portland's Rose Festival was the brainchild of civic boosters and today it has expanded into a weeks-long flurry of activities. Navy warships come to dock along Willamette River, a carnival is held, dragon boat racers row along a downtown stretch of river, the local newspaper hosts a city-wide treasure hunt, three parades occur, and one young woman is named the Rose Festival queen. The queen is chosen from a court of princesses elected by their fellow students to represent area high schools. Young women who aspire to be a Rose Festival princess must meet academic criteria and gain approval from a selection committee made up of local business and civic leaders ("In Defense of Rosaira," 1994). Students are then allowed to choose from the narrowed field of candidates. The fourteen Rose Princesses from each school move on to compete for the title of Rose Festival Queen (Boule, 1995). The Queen is judged on her appearance, poise, speaking ability, and leadership qualities. 
In 1994, at the Cleveland High School Rose Festival princess coronation assembly, four female students stood up to protest the event. They held up signs that read: "Objectification is not O.K." "Scholarship? Exploitation!" and "I'm Missing Class for This?" (Johnson and Jones, 1994, 6). The women were threatened with disciplinary action but then released and allowed to go back to class, as long as they promised not to disrupt the evening's ceremony (I. Hunter-Morton, personal communication, May 2, 2008). No one had ever before expressed public opposition to the Rose Festival pageant (Johnson and Jones, 1994). Most students responded positively to the action, and even those who didn't agree with its content, respected the women's right to protest. "I feel really good about this action because of the types of discussion it has created. Suddenly everyone is talking about it, I never knew there would be any other support," reflected one young protest organizer (Johnson and Jones, 1994, 6).

The contestants for Cleveland High School's Rose Festival Princess award were upset by the action. One candidate claimed it made her feel "degraded" and although the woman who was crowned princess "had no problem with the action," she was upset by its timing (Johnson and Jones, 1994, 6). A protester responded: "A lot of money is made from the Queen's Coronation. The fact that businesses and industries in the Portland area are using young women in this fashion makes me sick. It's exploitation" (Johnson and Jones, 1994, 6). Young adult women were not the only ones caught up in the Rose Festival pageant. Every year more than 800 nine and ten 
year old girls competed for eight slots on the Rose Festival Junior Court (Stewart, 1996).

As the local media covered the story of the Cleveland High School students' protest, the entire city was drawn into the debate about sexism in the Rose Festival pageant. More than 1500 Portland residents called a newspaper hotline to voice their opinions about the pageant (Eure, 1994). A majority who called felt it was a "sexist" or "outdated" tradition (Eure, 1994, B1). Fifty women joined in an action staged at the Rose Festival Queen's coronation. An organizing meeting was held to try and initiate a campaign to pressure the school district into withdrawing its support from the annual pageant. "It's been an immense response to what was really a very small protest" (Eure, 1994, B4).

Despite the emergence of a movement to abolish it, the Rose Festival pageant process continued as it always had that year. However, the voices of opposition refused to go away. Although Cleveland High School's protest leaders graduated, the next year more controversy erupted during the selection of the school's Rose Festival court. A young male student decided to compete in the event (Liljeholm, 1995). He did not qualify because of his gender. That year, the selection committee asked Cleveland High School's Rose Festival competitors: "Where would you go on a date if you had no spending money to take with you?" (Stacey, 1995, 6). The male contestant concluded: "If women ever hope to receive the respect they deserve, we need to stop seeing them as princesses and angels and allow them to come down from their pedestals and be people" (Liljeholm, 1995, 7). Students at Cleveland "had their 
consciousness raised" by the events of the previous year and discussions about the appropriateness of a school sponsored pageant continued on (Stacey, 1995, 6).

The ongoing controversy sparked an internal Rose Festival committee investigation into the Queen and Junior Court pageants (Bates, 1995). A bank official and former judge of the senior competition was asked to attend the Junior Court pageant to determine whether or not the selection process was harmful to the very young girls who competed. Based on his first-hand observations of the pageant and testimony from child psychology experts, the committee recommended the abolition of the Junior Court competition. The chair observed: "They bring [the girls] up ten at a time... I saw girls in shock and confusion. I saw girls apologizing to parents that they didn't make it" (Bates, 1995bb, L1). One columnist who attended a Junior Court selection process remembered the "smiling in the spotlights and the crying in the dark" that "went on for hours" as girls were summarily dismissed (Boule, 1995, B1). Child psychologists claimed that "girls who lose beauty contests are hurt and girls who win them are harmed" (Bates, 1995b, L1). The Rose Festival Association Board heard the testimony from feminists, psychologists, and concerned citizens, then took their internal committee's report into consideration. They announced that starting in 1996, the Junior Court would be abolished and replaced by a community service project and parade that both boys and girls could participate in (Stewart, 1996).

Four young women introduced the possibility that a Rose Festival princess could be judged by something other than her physical appearance. They stood up to a century of tradition to voice their points of view. No new communities grew out of 
their efforts, but the Rose Festival Association abolished the Junior Court pageant. Young girls no longer compete in a beauty pageant each May; for a brief time, they worked with their peers on a volunteer service project. The Rose Festival princess pageant remains a Portland tradition, but a template for change was established by the young protesters at Cleveland High School.

\section{Five Stories of Protest in the Pacific Northwest}

These five stories of protest in the Pacific Northwest provide insight into urban social movement development and dynamics. Each protest movement grew out of grievances that people had in their workplaces, neighborhoods, public services, the bricks and mortar of the metropolis, or in the imagination of their cities. These movements were grounded in the daily life experiences of their participants. They set out to transform the way their community labored, lived, learned, and imagined in the city. Chapter Eight assesses how successful these movements were at transforming the everyday lives of their communities. The impacts these protests had on the use of time, the production of urban space, the social relationships, and the sense of possibility within their communities of interest is explored. The interaction of these variables is examined and the ability of these five urban movements to create change beyond the boundaries of their communities of interest is considered. 


\section{CHAPTER EIGHT \\ THE IMPACT OF URBAN SOCIAL MOVEMENTS ON EVERYDAY CITY LIFE}

The first section of this dissertation established that the role of urban social movements is to transform the daily lives of their communities of interest. Earlier urban movement theorists looked beyond the city to see the impacts that locally-based movements make on urban life. The empirical data from Portland and Seattle revealed that urban movements were not trying to make large-scale changes, instead they challenged the ways in which people work, live and are cared for in the city. They contested the use of urban space and the collective imagination of their communities.

Five case-study movements were chosen from each of the areas that urban protesters contested. Chapter Six introduced an analytical framework for measuring the impacts these case-study movements had on the everyday lives of their communities of interest. This chapter presents how each of the case study movements changed their constituents' use of time, space, social relationships, and sense of possibility. The first section addresses the role that disruption plays in protesters' challenges to existing everyday life. The next part assesses the case study movements' abilities to change urban time, space, and relationships and to expand a community's possibilities. The following section examines the interaction of these four variables and the role each plays in ensuring social movement success. The chapter concludes with an examination of the impacts that the five case-study movements had on communities beyond their immediate constituencies. 


\section{The Role of Disruption}

Francis Fox Piven and Richard Cloward contended that the "most useful way to think about the effectiveness of protest is to examine its disruptive effects on institutions" (Piven and Cloward, 1977, 24). Each of the five urban social movements profiled in the previous chapter succeeding in disrupting institutional relationships in Portland or Seattle. These movements tapped into real concerns and issues that people had in their daily lives. Protest became vehicle through which people could express their frustrations with their conditions at work, in their neighborhoods, with public service delivery, land use patterns, and the dominant imagery of the city. Through organizing and protests, communities tried to wrest back control over their daily lives and pose solutions to the problems they faced. In each of these case studies, protesters forced change by disrupting everyday life.

Disruption is an effective tool when protesters play an integral role in the institutions they are trying to change (Piven and Cloward, 1977). Black students commanded the attention of the Portland school board by walking out of their classes. One student who attended a pre-boycott organizing meeting commented, "It's real hard to think about having to be out of school in order to be recognized when we're present in school" ("Black United Front Plans School Walk-Out," 1991,1). By staying out of school, students exercised their power to disrupt the educational system and communicated how essential their participation was to the functioning of that institution. Rose Festival pageant protesters used disnuption to express their opposition to a long-standing tradition.. High school students were expected to cheer 
and applaud during the coronation assembly, not hold up controversial protest signs. The Rose Festival protesters went from being passive audience members to becoming active participants, criticizing a ceremony they felt was sexist and outmoded.

In both of these cases, institutions had to take notice, because their constituents were no longer playing by the rules. Even when parents and community members picketed Portland School Board meetings, the district still refused to take action on the 12-Point Educational Improvement Plan. It was not until students boycotted school that the district considered issues of educational equity. Through the boycotts:

We were able to have an influence on a major institution that had, up until that point, been adversely affecting our lives and our community. People always tell you, you can't fight city hall, but collectively you can take some pretty strong direct action. You won't end up in jail or losing your job, like some people tell you. Civil disobedience can work, if you think it through and plan it carefully. If done well, it can have an impact (R. Herndon, personal communication, March 12, 2008).

The power to disrupt an institution lies with those whose consent is necessary to keep it functioning.

Some communities are so marginalized that their ability to disrupt most institutions is negligible (Piven and Cloward, 1977). Many poor communities are in this position. Homeless people in downtown Seattle were not essential to the functioning of any institution, outside of the social service system. Yet, they were 
able to force changes in the way downtown urban space was used. In the Operation Homestead's case, the homeless disrupted the Seattle real estate market by moving out of their place. The homeless in doorways or shelters do not pose a serious threat the exchange-value of downtown properties. But when the homeless occupy and reclaim vacant buildings, they are able to disrupt the normal flow of real estate transactions. In the case of the Gatewood Hotel, housing activists had tried to shame the owner into reopening the building to low-income tenants, and the city had even filed a lawsuit against him (Hatch, 1989). But shame alone could not thwart the power of real estate; it took the seizure of this property by the homeless to force the owner to sell it to a low-income housing developer.

The homeless were not the only community that moved out of their place to disrupt everyday life. Activists with the Coalition Against Weed and Seed were not supposed to be privy to the law enforcement plans for their neighborhood. The police wrote the Weed and Seed grant application with no community input, and activists only found out about it after the federal government awarded the grant to the city (Holloway, 1992a). In this case, the community disrupted the flow of federal money to the city of Seattle by moving out of their place in the neighborhoods and into the business of City Hall. In the midst of the Weed and Seed controversy, Seattle was shaken by two nights of rioting in response to the Rodney King verdict. Youth traveled out of their places in the surrounding neighborhoods and into the central business district to riot. These riots temporarily forced the city to acknowledge its problems with racism and police brutality and propelled the issue of Weed and Seed to 
forefront of local debates. The Coalition Against Weed and Seed solicited support from fifty-six organizations, and the first time the proposal came up on the City Council's agenda the coalition "shut them down" $(\mathrm{H}$. Walden, personal communication, April 7, 2008).

Communities gain the power to disrupt by moving out of their place. Moving out of one's place does not always imply geographical movement. It can also be accomplished by breaking down the invisible boundaries that keep communities apart. In the case of the Hotel Workers' Organizing Committee (HWOC), the housekeeping staff at the Hilton had to first move out of their ethnically divided places. Once these boundaries were bridged, low-income workers could then become a disruptive force in the workplace. Red Lion Hotel workers occupied the offices of the billionaire who owned the land their workplace sat on, disrupting his daily business. The Workers Organizing Committee (WOC) later turned the tables on the INS during their raids, by photographing abuses and holding agents accountable for their actions. These disruptive tactics were effective at forcing the authorities to pay attention to these movements, but did they create transformative change?

\section{Urban Movements and the Transformation of Everyday Life}

The impacts of urban movements are visible in the changes they produced in the use of time, the production of space, the social relationships and the sense of possibility in their community's everyday lives. Table 8-1 displays the effects that the five case-study movements had in each of these areas. Not every movement was able to transform their community's use of time, space or social relationships. But, each of 
these five movements created some form of change in their community's everyday

lives. A number of these changes were substantial, such as the addition of more than

300 low-income housing units in Seattle; others were miniscule, like the community

service project hours that briefly replaced the Junior Rose Festival Court pageant.

Table 8-1 The Impacts of Urban Social Movements on Everyday Life

\begin{tabular}{|c|c|c|c|c|}
\hline & Time & Space & $\begin{array}{l}\text { Social } \\
\text { Relationships } \\
\end{array}$ & $\begin{array}{l}\text { Sense of } \\
\text { Possibility } \\
\end{array}$ \\
\hline $\begin{array}{l}\text { (Hotel) Workers' } \\
\text { Organizing } \\
\text { Committee }\end{array}$ & $\begin{array}{l}\text { Workers able to } \\
\text { increase and } \\
\text { enjoy leisure time } \\
\text { Day Laborers use } \\
\text { waiting time }\end{array}$ & $\begin{array}{l}\text { Day-Laborer's } \\
\text { Center }\end{array}$ & $\begin{array}{l}\text { Immigrant worker } \\
\text { shared identity } \\
\text { Communities of } \\
\text { color find } \\
\text { common ground }\end{array}$ & $\begin{array}{l}\text { Community can } \\
\text { control the } \\
\text { workplace } \\
\text { Communities of } \\
\text { color have a right } \\
\text { to the city }\end{array}$ \\
\hline $\begin{array}{l}\text { Black United } \\
\text { Front School } \\
\text { Boycotts }\end{array}$ & $\begin{array}{l}\text { Families' use of } \\
\text { travel time to } \\
\text { schools }\end{array}$ & $\begin{array}{l}\text { Distribution of } \\
\text { students in } \\
\text { neighborhood } \\
\text { schools }\end{array}$ & $\begin{array}{l}\text { Multicultural } \\
\text { community of } \\
\text { interest }\end{array}$ & $\begin{array}{l}\text { Community } \\
\text { control of schools } \\
\text { Schools should } \\
\text { work for the } \\
\text { community } \\
\text { Multicultural } \\
\text { education }\end{array}$ \\
\hline $\begin{array}{l}\text { Coalition } \\
\text { Against Weed } \\
\text { and Seed }\end{array}$ & $\begin{array}{l}\text { Youth activities } \\
\text { and services }\end{array}$ & & $\begin{array}{l}\text { Asserting identity } \\
\text { of Central Area as } \\
\text { an African- } \\
\text { American } \\
\text { community }\end{array}$ & $\begin{array}{l}\text { Community } \\
\text { control of police } \\
\text { Blacks have a } \\
\text { right to the } \\
\text { Central District } \\
\end{array}$ \\
\hline $\begin{array}{l}\text { Operation } \\
\text { Homestead }\end{array}$ & $\begin{array}{l}\text { Alteration of } \\
\text { homeless people's } \\
\text { routines once } \\
\text { housed }\end{array}$ & $\begin{array}{l}300+\text { Units of } \\
\text { affordable housing }\end{array}$ & $\begin{array}{l}\text { Creation of } \\
\text { homeless } \\
\text { community }\end{array}$ & $\begin{array}{l}\text { Affordable } \\
\text { housing is a } \\
\text { priority } \\
\text { Low-Income } \\
\text { people have a } \\
\text { right to live } \\
\text { downtown } \\
\end{array}$ \\
\hline $\begin{array}{l}\text { Cleveland High } \\
\text { School Rose } \\
\text { Festival Pageant }\end{array}$ & $\begin{array}{l}\text { Volunteer hours } \\
\text { by former Junior } \\
\text { Court }\end{array}$ & $\begin{array}{l}\text { Eviction of Junior } \\
\text { Court from public } \\
\text { schools }\end{array}$ & & $\begin{array}{l}\text { Women should } \\
\text { not be judged by } \\
\text { appearance alone }\end{array}$ \\
\hline
\end{tabular}

Protest

Regardless of the potency of these effects, protesters still created concrete

transformations in people's lives that over time may have contributed to larger-scale 
changes. Jeri Williams, a former hotel worker who now works to promote diversity in city programs, mused:

Where would my life have been different had these people [HWOC] had never been in my life? It would be totally different. I wasn't working at the hotel thinking that someday I'm going to work at the city for the mayor to fund diversity programs (personal communication, February 5, 2008).

Just as the Hotel Workers Organizing Committee opened up a new sense of possibility in Jeri Williams' life, urban movements can expand the potentialities of an entire community. These five case study movements opened up new possibilities for daily life in both Portland and Seattle during the 1990s. The HWOC and the WOC introduced the idea that the local state could act to protect workers' rights. The Workers' Bill of Rights, the petitions to stop Metro regional government from subsidizing anti-union hotels, and the proposal to create a Day Laborer's Center all forced local government to take a side in the struggle between capital and labor. In addition to defending labor rights, the HWOC and WOC demonstrated the possibility that multicultural organizing was not only necessary, but extremely effective. Peter Cervantes-Gautschi believes the most important legacy of these organizations was the notion:

that it was actually possible to get together with folks, not just like you, but particularly people who were not like you and make a difference. It is possible to create those kinds of alliances and relationships, and 
whenever we were successful, those were the elements (personal communication, January 24,2008$)$.

Once people came together in a social movement, they could then entertain the possibility of taking control over their own lives. The Black United Front's 12-Point Educational Improvement Plan challenged the idea that school district officials knew what was best for all students, and instead proposed a model of community-control. Community-control meant that the district should be held accountable to students and families and that parents and children must have a say in the decisions made in their neighborhood schools. The BUF also advocated for a more multicultural curriculum that reflected the experiences of all Portland Public School students. Even thought the district failed to adopt baseline essays which outlined the contributions all racial and ethnic groups made in various subject areas, the curriculum has still come a long way from where it was fifteen years ago. At least "now there is a discussion about black history, it's not enough, but before that there wasn't even a discussion during that period of time, just some singing and that was it" ( $R$. Herndon, personal communication, March 12, 2008).

The Coalition Against Weed and Seed also advocated for greater community control. They demanded input into the policing tactics that would be used in their neighborhood and exposed Weed and Seed as a "people removal project" designed to facilitate the gentrification of inner city Seattle $(H$. Walden, personal communication, April 7, 2008). By confronting the issues of gentrification and displacement, the anti- 
Weed and Seed movement asserted the African-American community's right to decide the future of their central Seattle neighborhoods.

Operation Homestead expanded the possibilities for low-income communities in downtown Seattle. Prior to their building occupations, thousands of low-income units were slated for demolition or conversion. Through the renovation of these vacant buildings into permanent affordable housing units, Operation Homestead created the space for low-income people to continue to live downtown. In addition, they drew attention to the housing crisis that plagued the city. The more than two hundred people who sought temporary shelter in the Pacific Hotel illustrated the sheer immensity of the housing need in Seattle. These occupations opened up the possibility for a citywide affordable housing initiative that was put on the ballot in 1995 .

Rather than establishing a community's right to exist within a city, the Rose Festival protesters tried to redefine what it meant to be female in Portland. By endorsing the Rose Festival Princess pageant, city leaders and business boosters perpetuated stereotypical portrayals of women. The Rose Festival protesters questioned the idea that women should be judged by their physical appearances. At a speak-out against the pageant, one high-school student lamented, "all those hours I spent putting on makeup, doing my hair, trying to look good. I wish I had those hours back" (Eure, 1994, B1). By challenging the traditional images of women that the Rose Festival pageant sanctioned, these protesters demanded that everyday female routines change. 
Another aspect of everyday life these five movements transformed was the social relationships within their communities. In three of the case study movements, new communities were created through urban protest. The HWOC and WOC broke down self-imposed and employer-mandated ethnic barriers that kept the immigrant workforce apart and transformed these separate cultural communities into a unified organization of immigrant and low-wage workers. HWOC and WOC recognized that in order for multicultural organizing to be successful, communities must be allowed to retain their cultural identities. Jeri Williams explained it like this: "First you have to be yourself or else you'll be tokenized and blend in with others and then you've lost your specialness, you've lost who you are" (personal communication, February 5 , 2008). The Black United Front's educational equity movement also evolved into a multicultural effort. The Front had always emphasized the commonalities that lowincome and minority students faced in the Portland Public School system: "We are concerned about the black youngsters in this community, but we are concerned about other youngsters too, and the gains will be gains that can be shared" (Meehan, 1990, A4). During the 1990 boycott, the BUF argued that all students should be alarmed at the state of academic achievement, because the education they were getting was inadequate to prepare them for the global economy. Despite these arguments, support for the boycott was primarily centered in the black community. By 1997, the movement had grown to include the Latino, Vietnamese and Native American communities. This change came about because the demographics of schools had shifted, but it was also the result of a concerted effort to build cross-cultural 
relationships and alliances (R. Herndon, personal communication, March 12, 2008). Operation Homestead broke down the barriers between housing advocates and the homeless. Homeless people had taken part in housing actions before, but Operation Homestead, SHARE and WHEEL built a movement that was led by affected people, based upon the principles of self-determination, autonomy and empowerment, rather than top-down advocacy (J. Fox, personal communication, April 4, 2008).

The Coalition Against Weed and Seed helped strengthen an existing community. The Coalition asserted that the Central District was a black community and that African-Americans needed to have control over what went on within the neighborhood. They successfully lobbied for black representation on Weed and Seed community advisory committees, winning a resolution that barred the substitution of wealthy, white-dominated block watch organizations for more representative community groups (Holloway, 1992b). By asserting the black identity of the Central Area, the Coalition Against Weed and Seed ensured that the community had at least some control over its future.

Changing social relationships can be difficult to see if they are not embedded in a particular urban space. Lefebvre (1991) asserted that a movement that fails to transform urban space is ultimately incapable of creating any significant lasting social change. Four of the five case study movements transformed urban space, although the degree that they were able to accomplish that task varied. Operation Homestead had the most dramatic impact on urban space. Their building occupations led directly to the creation of more than 300 units of affordable housing. The WOC created a visible 
space for low-income, immigrant workers in the city, although it took more than a decade for it to come to fruition. The Day Laborer's Center will not only provide a safe space for workers to gather, but it also guarantees immigrant workers' right to earn a living within the city of Portland.

Other spatial changes were less visible and obvious. While the BUF school boycotts in the 1980s made significant spatial changes for African-American students and families by ending the system of forced busing, the spatial impacts of the 1990s boycotts were less recognizable. The later boycotts changed the decision-making processes and activities that went on within the spaces of neighborhood schools. Rose Festival protesters also achieved a partial victory. They managed to evict the Junior Pageant from Portland elementary schools, but the high school level competition remains an annual tradition.

Transforming urban spaces initiates changes in the daily routines of the users of that particular space. The conversion of abandoned downtown buildings into affordable housing radically altered the routines of the people who eventually lived there. For those who were homeless prior to moving into a unit, the daily search for shelter was eliminated from their routine. They no longer had to locate for public restrooms or worry about how they would safely store or transport their possessions. Housing stability provided increased economic opportunities. Having an address made it easier to look for work, get adequate rest, maintain their appearance and ultimately hold down a job. Finally, housing provided a safe place where people 
could practice their cultural and spiritual traditions and maintain ties with family and friends.

The BUF changed the daily routines of black families with children in Portland. The 1980 boycotts ended the one-way busing system that forced black students to attend schools outside of their neighborhoods. Keeping children closer to home meant "parents no longer had to run all over town for their kids' sports and after school activities," and it "got students out of that segregated setting and into a setting where they could have dignity" (Herndon, personal communication, 2008).

The HWOC and WOC transformed the low-income workers' use of time. By gaining wage and benefit increases, immigrant workers increased their leisure time. Rather than devoting more than forty hours a week to work, they were free to spend time caring for family, earning more money, getting an education, enjoying leisure activities or contributing to their communities. Day-laborers may also experience a transformation in their daily routine once the workers' center opens. Instead of arriving at the corner before sunrise to compete for a limited number of jobs, workers can wait in a warm, dry place where they will be matched with an appropriate employer. The center will also house educational, social service, and cultural programs. While they are waiting for work, day laborers can study for a degree, make art, or find affordable housing or health care.

The Weed and Seed and Rose Festival protests had less of an impact on the use of time in their communities. The additional money spent on the "seed" portion of the grant allowed for the expansion of youth employment and enrichment activities. 
These activities provided a constructive and educational way for young people to spend their leisure time. The Coalition fought to ensure that young AfricanAmericans would have access to those programs (H. Walden, personal communication, April 7, 2008). The Rose Festival protest also had a minimal impact on women's use of time. Nine and ten year old girls no longer wasted a day primping and competing in a beauty pageant, and for a brief period of time, they instead participated in a community service project.

\section{The Interaction of Time, Space, Social Relations, and Possibility}

An Ecuadorian activist reflecting on her work with an indigenous rights organization commented: "Something very fundamental has emerged for us from this experience, a sense of possibility" (Collins, 2000, 45). The creation of new possibilities is an essential function of social movements. Social movements bring about new potentialities for those who participate in them (Melucci, 1989). Through the public performance of protest, these new possibilities are communicated to a wider audience. In addition, urban social movements draw attention to the routines of everyday life. By exposing the everyday as such, urban movements transform daily life from a habitual action to a conscious participation in institutions, systems or relationships (Sheringham, 2006). The possibilities that movements introduce may not come to fruition within the lifetime of that particular organization or coalition, but they expand the boundaries that new movements arise under.

In addition to introducing new possibilities, the protest experience forges new identities and communities (Fantasia, 1988; Melucci, 1989). The construction of new 
alliances and social relationships is another essential way that movements alter the communities they occur in. Just as with new possibilities, new social relationships do not guarantee immediate change. However, if these relationships are enduring, they have the power to re-emerge and challenge the status quo again.

A sense of possibility and the creation of new social relationships form the base from which movements can launch their efforts to create more lasting, fundamental transformations in everyday urban life. Figure 8-1 shows the interaction of time, space, social relationships and sense of possibility in urban social movements. The introduction of a renewed sense of hope is the basis upon which urban movements create change. A movement that fails to communicate any new sense of possibilities will also fail to transform urban space or a community's use of time. The other base from which urban social movements create change is the social relationships they form. A movement that forges no new social relationships leaves no legacy from which it can continue to struggle once the initial protest dies down. This was the case with the Rose Festival pageant protest. The Rose Festival became just another issue that an already established community of feminists to rallied around. The initial protest was inspired by a small group of young women who had sat silently through the pageant for three years, feeling no connection to the portrayals of womanhood on the stage (I. Hunter-Morton, personal communication, May 2, 2008). Their actions and issues were quickly embraced by Portland's feminist community. The original protest organizers graduated soon after their action and many left town. Once the Festival board agreed to abolish the Junior Court, the issue lost its urgency within the 


\section{Figure 8-1}

The Interaction of Everyday Life Variables in Urban Social Movements

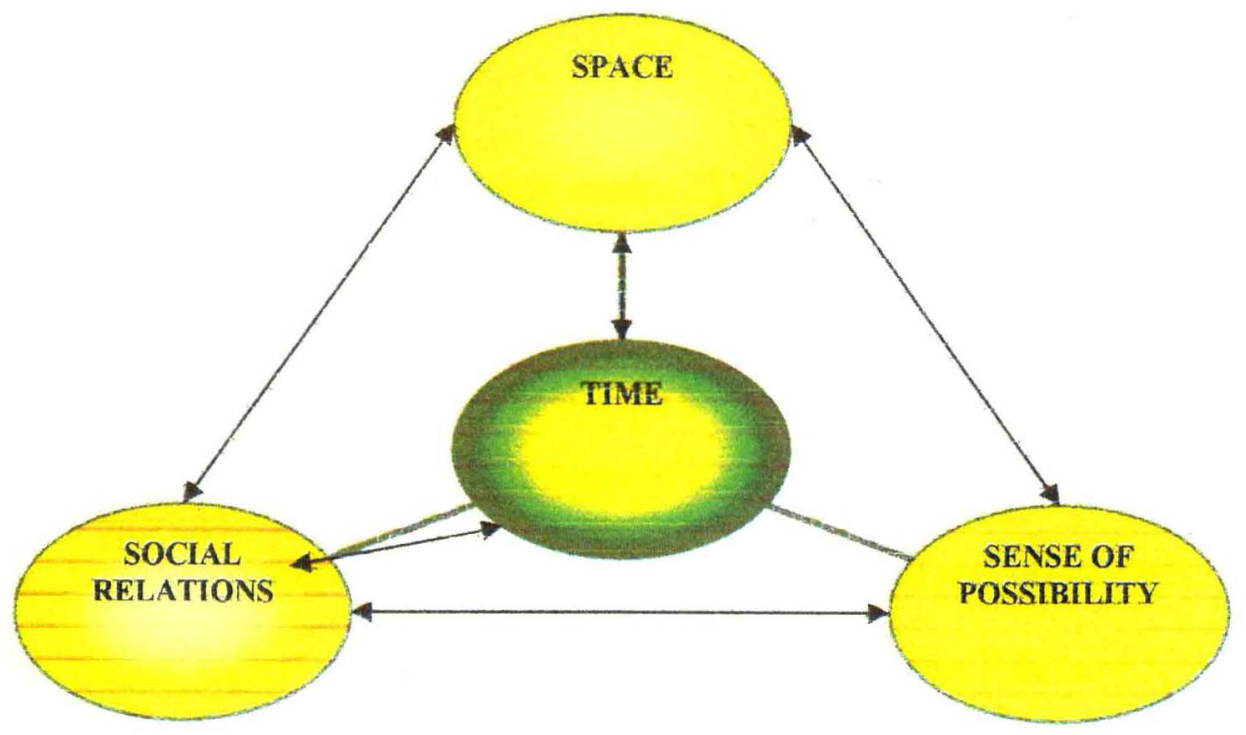

feminist community. By 1995 , the women's movement was facing an increasingly militant anti-abortion movement headquartered in Portland (Bates, 1994). Cleveland High School, where the Rose Festival pageant protest started, felt its reverberations the following year, but students quickly forgot the controversy. Had the Rose Festival protesters succeeded in creating a new community within Cleveland High School, the disruption of the coronation may have become an annual event.

The construction of new social relationships and communities enable a movement to weather the lulls in the protest cycle (Della Porta and Mosca, 2007). During the lags in movement activities, activist communities strengthen and reconstitute themselves. The protesters that shut down the WTO meetings in Seattle spent the years leading up to that action building the informal activist network that 
would eventually shut down the trade conference. The relationships that were built through the HWOC and WOC continue on today, even though those organizations no longer exist:

Every one is still doing great work....a lot of it was Peter CervantesGautschi, Mr. Connections! He probably created more organizers of color in the state of Oregon than anybody else. All of the other groups that have done well, he was a part of it, just his eye for leadership and making investments in people. We're still here and we've got each others' backs! (J. Williams, personal communication, February 5 , 2008).

Although the organizers who were trained through the HWOC and WOC are scattered around the city and even throughout the country, many of them recently rallied together to support a local proposal to rename a city street after César Chávez. The street renaming effort failed, but it opened up a new sense of possibility for communities of color in Portland:

The renaming effort left a lot of people very depressed, including the people who voted against it, because now for the very first time they have to look at the possibility that they may be racist. Organizing is educational; it's bringing us all to a new level of awareness ( $\mathrm{J}$. Williams, personal communication, February 5, 2008).

The creation of a new sense of possibility and the development of new social relationships often go hand-in-hand. 
The practice of protest establishes new social relationships and communicates its sense of possibility out to a wider audience, but the goal of urban movements is to transform the daily lives of their communities of interest. Daily life is structured by urban space and day-to-day routines are constricted by temporal boundaries. In order to leave a lasting impact on the daily community life, movements must transform how everyday space and time are constructed. Each of the five case-study movements were able to, at least temporarily, change their community's use of time.

Operation Homestead transformed poor people's daily routines in downtown Seattle by creating new units of affordable housing. The HWOC and WOC gained better wages and working conditions in low-wage industries. The Coalition Against Weed and Seed kept young people out of prison and funded job-training and afterschool programs for neighborhood youth. Often times, these transformations in a community's use of time can serve as a building block to perpetuate and sustain a social movement. After Jeri Williams was injured on the job, the HWOC helped her get Worker's Compensation and appropriate medical care (J. Williams, personal communication, February 5, 2008). She joked that her life would have been completely different if she had never hurt her back, but in reality, the support she received from HWOC organizers helped Williams to realize her potential as a community leader. Figure 8-1 shows how changes to a community's use of time can result in renewed social relationships. By transforming the way Jeri Williams used her time, the HWOC gained a strong and capable leader. Jeri Williams was responsible 
for leading the Red Lion anti-toxic campaign, founding the first local environmental justice organization and working to unionize parking attendants.

Sometimes the changes to a community's use of time are temporary. Weed and Seed activists procured funding for youth programs, but once the gentrification of their neighborhood was complete, this funding went away. The abolition of the Rose Festival Junior Court resulted in briefly-lived alternative community project. A few years after the Junior Court abolition, the community service alternative also died.

When a movement succeeds in altering urban space within their communities, the use of time will be more permanently transformed. Figure 8-1 shows that the transformation of urban space is the pinnacle of local movement activity. Four of these movements changed the way space was used in their communities. Three of them succeed in creating new spaces: the BUF established neighborhood schools by ending the one-way busing policies, WOC set-up an indoor center for day-laborers, and Operation Homestead created more than 300 units of affordable housing in downtown Seattle. The Rose Festival protesters succeeded in evicting the Junior Court pageant from elementary schools, but they were unable to create any new spaces.

The transformation of urban space is not only a victory in and of itself; these new spaces permanently enshrine the other changes that urban movements make. The inability to transform urban space resulted in fleeting adjustments to everyday routines that disappeared when a movement died. The Coalition Against Weed and Seed was unable to completely take control over the spaces of the Central District. A leader in 
that movements remarked: "It really was heroic to fight against them," but ultimately the struggle taught the city and the police how "to organize around the opposition" ( $\mathrm{H}$. Walden, personal communication, April 7, 2008). Weed and Seed was just one effort in the community's larger campaign to resist gentrification. Today, the Central District is no longer a majority black neighborhood (Kossen, 2005). The Weed and Seed struggle may have bought the community more time, but ultimately "black people didn't have the resources" to defeat the economic and political forces behind gentrification ( $\mathrm{H}$. Walden, personal communication, April 7, 2008). It was a "David and Goliath" match; five hundred years of "unparalleled violence against black people and Native Americans" was difficult to overcome (Walden, personal communication, April 7, 2008). Had the Weed and Seed activists succeeded in stopping the gentrification of their community, they may have been able to create more economic opportunities for neighborhood youth within the spaces of their community.

The construction of new urban spaces also sustains the social relationships and sense of possibility that movements create. The Black United Front boycotts of the 1990s were predicated on the victories they won in the 1980s. Ron Herndon believed: "It is much easier to turn a school around if it is around the corner from you than if it is across town" (personal communication, March 12, 2008). The establishment of neighborhood schools opened up the possibility for community-control of those spaces. WOC's day-laborers center will provide space for cultural events, social services, and political meetings for immigrant workers. This space will help maintain 
the relationships that day-laborers have built with one another and allow them to expand their networks beyond the immigrant workforce.

Urban social movements beyoud their community of interest

Urban social movements may transform the everyday lives of their communities of interest, but why should these movements matter to anyone outside of those who are immediately impacted by them? Figure $8-2$ shows that the impacts of urban movements have the potential to spill out beyond the borders of their immediate communities. Urban movements are like stones that are thrown into a large body of

\section{Figure 8-2 Urban Movement Impacts Beyond the Boundaries of Community}

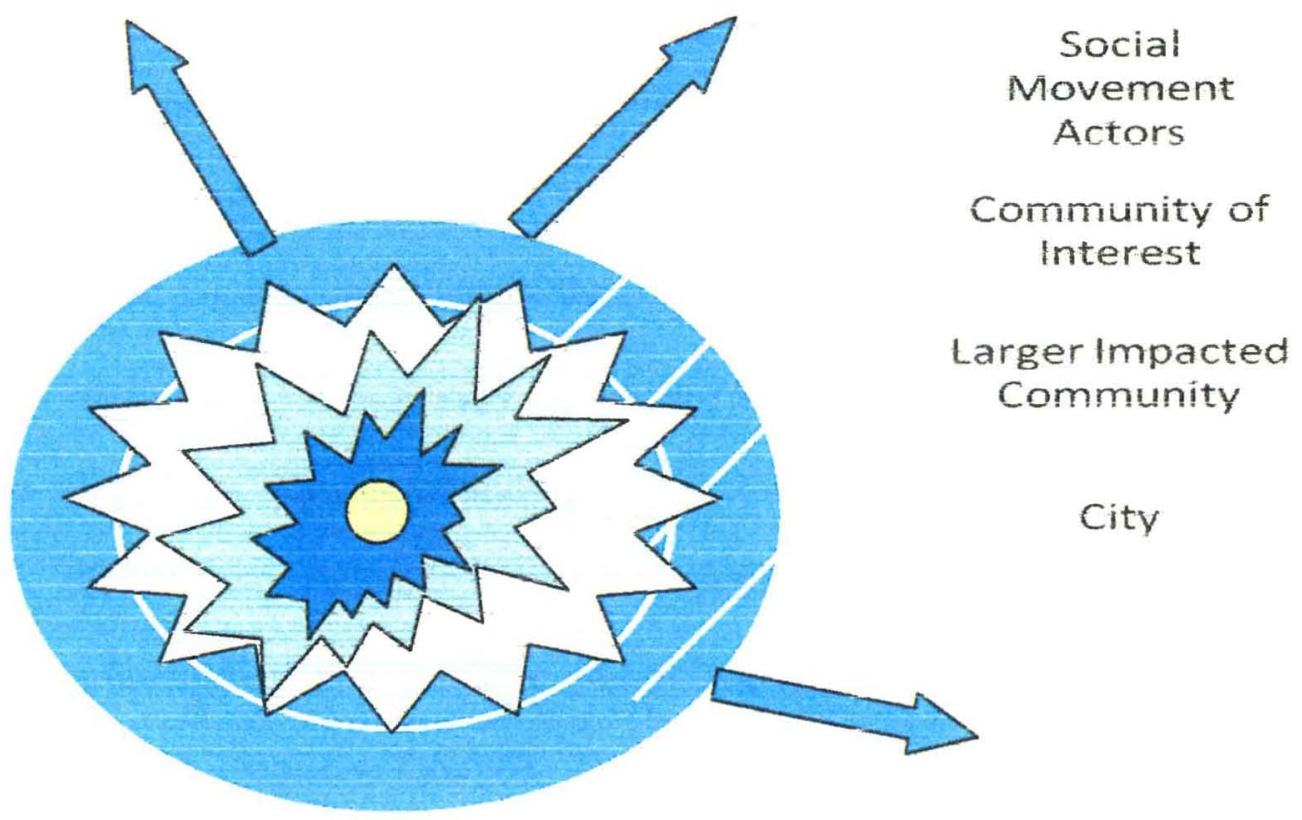

of water. As a stone is thrown with greater force, it creates stronger and larger ripples. A particularly strong urban movement can ripple out beyond the boundaries of its 
immediate community. The HWOC built upon their successes in the hotel workers' campaign to expand their mission to low-wage workers in other industries. The Black United Front also expanded its community of interest to incorporate the growing Latino, Asian and Native American communities.

Sometimes other communities learn from the experiences and victories of urban social movements. Social movement scholars call the process of transferring information between movements, diffusion (Della Porta and Diani, 1999). Movements halfway around the world may borrow tactics, ideas and even slogans from other protesters. The success of Operation Homestead's building takeovers diffused out to other neighborhoods in Seattle. Homeless youth were inspired to squat empty homes owned by the University of Washington (J. Fox, personal communication, April 4, 2008).

Diffusion can also occur beyond the borders of a city. The Coalition Against Weed and Seed may not have stopped gentrification in the Central District, but they did share information with other communities about the Justice Department's program. "We sent information to Los Angles, Newark and Las Vegas. In Newark they managed to make it work for them. In Las Vegas, they used the funding to train young people for construction jobs" (H. Walden, personal communication, April 7, 2008). Seattle was one of the first cities to receive Weed and Seed grant money, and the community response to the program helped inform and inspire resistance elsewhere. The WOC also reached beyond the borders of Portland to transform the lives of low-income workers in other places. Although the city failed to fund a day- 
laborers' center in the mid 1990s, WOC organizers helped secure funding in other cities. "Our people were down in L.A., they were down in San Francisco; they were helping to form that whole national network of immigration rights. They played a real active role in that" (J. Williams, personal communication, February 5, 2008). This organizing in other places eventually helped the cause back in Portland. The strong national immigrant rights movement and the success of day-laborer centers in other cities created a climate that allowed for the construction of a workers' center in Portland (Maushard, 2007).

Urban social movements have the capacity to make impacts that affect the entire city. The Workers Organizing Committee successfully passed a fair-wage ordinance in Portland (Sten, Kafoury, and Francesconi, 1998). This resolution guaranteed a living wage to any city-subsidized employee. The Black United Front secured a framework that allowed for more community-control in schools across the district. Site councils were mandated in statewide educational legislation, but the 1991 BUF boycott determined what the composition of those councils would be in Portland (R. Herndon, personal communication, March 12, 2008). Instead of a council dominated by district employees, Portland Public School site-councils are required to have equal parent, teacher and community representation. In Seattle, the affordable housing gains that Operation Homestead made downtown spilled out to other poor people in the city. Operation Homestead and the rejuvenated housing movement in Seattle passed a $\$ 50$ million levy to create more affordable units across the city (J. Fox, personal communication, April 4, 2008). 
Even if urban movements succeed in making citywide transformations, can they ever really achieve a change in urban meaning? Castells (1983) defined urban meaning as the role that cities play in larger social structures. In the 1990s, Seattle was a "Pacific City," oriented towards global interests (Abbott, 1992). Despite the best efforts of activists from groups like Operation Homestead and Mothers Against Police Harassment, Seattle remained determined to invent itself as a "spectacular" city by the end of the decade (Gibson, 2004). Even though activists could not burst the city's speculative bubble, they did manage to deflate some of the most egregious gentrification efforts. Weed and Seed activists stalled the federal policing program for entire year, and the version that was eventually adopted looked nothing like the original. In addition to thwarting the city's speculative plans, Seattle activists were able to build permanent spaces that enshrined and alternative vision of the city. Jenny Pickerall and Paul Chatterton (2006) call these real and imagined spaces that social movements create, "alternative geographies." Operation Homestead created an alternative geography of 300 units of permanent affordable housing in downtown Seattle. These units will always serve the use-value of their tenants and will never succumb to the speculative activities of the next downtown land-grab. Poor people are cemented their right to remain in downtown Seattle through this alternative geography of affordable housing units.

The downtown poor were not the only people threatened with displacement in this Pacific City, activists in the Central District were also angry about the gentrification of their neighborhood. As they became displaced and scattered 
throughout the metropolitan region, they suffered an irreparable loss of their place in the city. However, an alternative geography continues to exist in the Central District. In addition to the black families and businesses that remain, earlier social movements established the Langston Hughes Cultural Arts Center and an African-American museum. Those cultural centers will always remain black community spaces, no matter how white-washed the neighborhood around them becomes. These spaces of resistance may one day provide a base for future movements to reclaim their lost places in the city.

Portland's "Regional City" status meant its fate was tied to the rest of the Pacific Northwest (Abbott, 1992). As the region went, so did the city, and vice versa. Portland politics were dominated by the culture wars between the right and the left in the early to mid-1990s. Urban social movements played in integral role in fighting some of those battles. Anti-Racist Action, the gay and lesbian rights movement and women's clinic defenders put their bodies on the line to defend the ideal of a tolerant Portland. Today, Portland is known in the rest of the country as a progressive city, where alternative cultures can flourish (Florida, 2008). That wasn't always the case. Had the skinhead movement triumphed in the early 1990 s, the city might be thought of as Coeur d'Alene, Idaho, with better transit service. Had anti-abortion activists and the OCA had their way, Oregon might be Kansas with topography. But that was not the case. Portland's urban social movements--including the Black United Front, the Rose Festival protesters, and the Workers' Organizing Committee-- placed issues of race and gender at the forefront of their struggles. These movements, protest by 
protest, constructed a more tolerant city. At times, that tolerance was only skin-deep. When the Black United Front wrote an African-American Baseline Essay to help guide the formation of a multicultural curriculum in Portland, the school district refused to adopt it, citing concerns with its historical accuracy. The baseline essay was ultimately used in a number of school districts across the country, where it became known as the Portland Baseline essay. "It was ironic, because it was called the Portland Baseline Essay, but it was never used in Portland" (R. Herndon, personal communication, March 12,2008). Race and gender remain deeply contested issues in the city of Portland and future urban social movements will continue to shape these relationships across the region.

According to Andy Merrifield (2002), urban social movements defend the virtues of urbanism, or the use-value of city life, against the forces of urbanization, or the primacy of exchange-value. Castells (1983) imagined a similar struggle that pit use-value, cultural autonomy, and community-control against the forces of capital, the state, and technocracy. In these views, the city must embrace either one path or the other. Castells believed that movements that fail to transform urban meaning, have failed to create meaningful change. However, this project demonstrates that urban social movements do matter. They matter because they transform the everyday lives of urban communities. Weed and Seed activists may not have been able to combat the gentrification of the Central Area, but they did manage to save neighborhood youth from federal police harassment and the specter of boot camps. Weed and Seed activists changed the nature of federal criminal justice policy in Seattle and across the 
country. Social institutions are not just top-down projects imposed by higher-level actors, they are constructed, contested, and re-constructed in people's everyday lives (Pred, 1986). Doreen Massey (1994) envisions that city not as a place on a map, but as a space of interaction. In this space of interaction, movements construct new social relationships and institutions that result in new ways of living our everyday lives. Sometimes that process of change diffuses out to the city as a whole and even beyond it. In addition to the changes they create in daily community life, urban movements matter because they do have the potential to transform everyday life on larger levels.

Ultimately, these stories teach us that urban movements do substantially transform the everyday lives of their communities. Scholars and activists alike must remember:

That if you move as a community, then there is a possibility that you will bring about significant change. Individuals can try and do that, but they get lonely and are ineffective. But as a community, you can make significant change. This was the most radical change that ever occurred in Portland Public Schools, and it is because we had a determined, informed and organized community (R. Herndon, personal communication, March 12, 2008).

Communities continue to move together and take control over their everyday lives in cities throughout the globe fundamentally transforming the places we call home. 


\section{$\underline{\text { References }}$}

\section{Newspaper Article and Media Reports}

Activists end vigil at deserted building. (1989, August 29) The Seattle Times, p. D3.

Alternative classes set-up. (1991, February 4, 7:54 a.m.) KINK FM Radio.

Ames, S.C. (1990a, February 20). Street march, cleanup, protest. Oregonian, p. B4.

Ames, S.C. (1990b, October 4) Clark says letter is explanation, not apology for criticism of police, The Oregonian, p. D3.

Amick, S. (1996, July 26). Southeast area protests paroled child molester, Oregonian, p. C2.

Angelos, C: (1989, August 11) Ellis and housing advocates square-off over McKay apartments. The Seattle Times, p. C3.

Angelos, C. (1990a, January 21) Anti-drug rally focuses on citizen action, Seattle Times, p. B2.

Angelos, C. (1990b, August 2) Protesters greet visiting navy fleet -Anti-Nuclear message for Seafair sailors, Seattle Times, p. D1.

Angelos, C. (1992, September 30) Squatters' protest tactics find a home-advocates for housing boast victories. The Seattle Times, p. E1.

Angelos, C. and Birkland, D. (1993, November 9). Homeless take to the streetsProtesters, ACLU decry new city laws meant to curb public drinking, begging. Seattle Times, p. B3.

Angelos, C. (1994, February 2) About 50 people, Seattle Times, p. B2.

Angelos, C. Bock, P. and Pryne, E. (1992, May 2). 30 arrested in $2^{\text {nd }}$ night of Seattle strife-disturbances on Capitol Hill shift downtown. Seattle Times, p. A1.

Angelos, C. and Broom, J. (1990, January 23) 60 demonstrators arrested-Crowd rallies to demand end of El Salvador aid; Marchers clog commuter traffic, Seattle Times, p. C1.

Axley, M. (1993, September 8) $15^{\text {th }}$ Avenue Market yields to picket line, The Skanner, Portland Edition, p. 1. 
Badgirl, B. (1993, October) Lesbian Avengers protest harassment on Tri-Met buses. The Alliance, Vol. 13, 10, p. 5.

Baker, N. (1992, September 27) Trouble in timber town. The Oregonian, p. L1.

Balter, J. (1991, October 6) Some discordant notes As Music Hall starts coming down, Seattle Times, p. A1.

Bates, T. (1994, October 21) Champion of life and killing, The Oregonian, p. E1.

Bates, T. (1995a, January 15) Anti-abortion group protests in front of physician's home, The Oregonian, p. D8.

Bates, T. (1995b, July 30) Kingdom of Rosaria awakens to its thorns. The Oregonian, p. L1.

Benson, M. (1997, January 30). Musicians union plans rally outside $5^{\text {th }}$ Avenue Theatre. Seattle Times, p. E2.

Bernstein, M. (1999, October 21) Some police Changes, Calls for change, The Oregonian, p. D3.

Birkland, D. (1993, May 19) Hotel sale to open door for needy-Seafirst Bank announces it's selling Pacific Hotel. The Seattle Times, p. B4.

Bjorhaus, J. (1995, June 29) Peaceful protesters get SWAT treatment. The Seattle Times, p. B4.

Bjorhaus, J. and Norton, D. (1995, June 27) Two housing advocates arrested for sitin, Seattle Times, p. B3.

Black United Front blasts school board. (1991, January 28, 10:23 p.m.) KPTV 12 News.

Black United Front calls for boycott of Portland public schools. (1990, December 10, 11:00 p.m.) KATU News.

Black United Front plans school walkout. (1991, January 3, 10:02 p.m.) KPTV 12 News.

Blackmaun, M. (1988, November 10) 60 Protestors block bridge, The Oregonian, p. F1. 
Boule, M. (1989, November 7) Local hostages. The Oregonian, p. B1.

Boule, M. (1995, July 30) A royal opportunity. The Oregonian, p. B1.

Boycott backers canvas neighborhood. (1991, January 20, 5:05 p.m.) KATU News.

Bradford, K. (1994, July 31) Domestic abuse: Details are what hurts, The Oregonian, p. C6.

Broom, J. (1991, April 5) Low child care pay protested, Seattle Times, p. E2.

Broom, J. and Byrnes, S. (1997, February 6) Bicycle activists set downtown rally to protest arrests, Seattle Times, p. B1.

Broom, J. and Hatch, W. (1989, July 1) Homeless protest brings 10 arrests. The Seattle Times, p. A1.

Brown, C. (1991a, February 15) Telling students it's OK to be gay, Seattle Times, p. B2.

Brown, C. (1991b, May 2) Activists occupy vacant building. The Seattle Times, p. C1.

Brown, C. (1991bc May 20) Activists force protesters from closed hospital-Exworkers in West Seattle demand back wages, Seattle Times, p. B4.

Cleveland High Students Protest School's Plan (1996, November 6) Seattle Times, p. C2.

Clutter, S. (1990, January 7) Residents against drugs laud apartment evictions, Seattle Times, p. B2.

Crisis team target 14 schools: Superintendent Ben Canada pledges his support for effort. (1999, June 23) The Skanner, Portland Edition, p. 1.

Daniels, L. (1994, October, 18). Wilson High sees race protest, Oregonian, p. B1.

Daniels, L. and Nkrumah, W. (1994, November 17) Minority students still seek change, The Oregonian, p. C1.

Danks, H. (1991, January 13) Throngs demand peace in the Gulf, The Oregonian, p. A1. 
Darienzo, M. (1994, October). End embargo on Cuba. The Alliance, p. 5.

Dawson, B. (1993, May) Women take back Sandy Blvd. The Alliance, Vol. 13, 5, p. 4.

Demonstrators parade school board. (1991, January 24, 11:12 p.m.) KGW8 News.

Denn, R. (1991, June 27) Gays stage wedding protest at county licensing office, Seattle Times, p. $\mathrm{C} 11$.

Dietrich, B. (1991, January 23) War brings diverse groups to the streets--Networking activists Seen as a factor, Seattle Times, p. A6.

Di Rado, A. (1996, February 23) Teachers protest stalled contract talks, The Oregonian, p. C5.

Di Rado, A. (1997, May 9) School Board Averts Minority Boycott, The Oregonian, p. C1.

DiRado, A and Carter, S. (1997, June 11) Portalnd gives school an "F," Erases teachers, The Oregonian, p. A1.

Douglass, M. (1992, June 10) Youth and adults rap on racism, attack Weed and Seed. The Skanner, p. 3.

Ellis, B.C. (1992, April 17) Mayoral front runners agree with city's plan for homeless, The Oregonian, p. B5.

Emergency meeting draws large crowd. (1992, April 15) The Skanner, Seattle Edition, p.1.

Eure, R. (1994, June 1) Pageant protests gathers steam, The Oregonian, p. B1.

Farrell, P. (1998, August 18). Police disperse protesters on MLK, Oregonian, p. B7.

Farrell, P. and Trujillo, L. (1998, August 19). Protest brings differing accounts. Oregonian, p. Al.

Fitzpatrick, T. (1998, March 5) Black students not treated fairly, Roosevelt high students tell board, Seattle Times, p. B2.

Focusing on the plight of the homeless. (1989, June 27) The Seattle Times, p. A1. 
Foy, J. (1993) Test scores plunge at N/NE schools. The Skanner, Portland Edition, p.1.

Gardner, F. (1994, April 18). Neighbors rally for school, Oregonian, p. B6.

Gaynair, G. (1999, March 21). Protest, chants demand end to curfew, Oregonian, p. D7.

Gilbert, H. Manzano, P. and Rollins, M. (1992, May 2). Speakers urge calm at rally on PSU campus, Oregonian, p. A11.

Glover, D. (1990, September 26) $\$ 400,000$ to help the market's poor. The Seattle Post-Intelligencer, p. B3.

Godes, K. (1990, September 1) Nephews take control over Sam Israel's empire. The Seattle Post-Intelligencer, p. A1.

Gonzales, N. (1995, March,30). 16 arrested near dome at sit-in for homeless, Seattle Times, p. B1.

Goranson, E. and Kohler, V. (1994, January 14) PGE employees protest job-change proposal, The Oregonian, p. C5.

Gough, W. (1990a, September 9) Metro displays West Point but protesters persevere, Seattle Times, p. B2.

Gough, W. (1990b, October 21) Nationwide protests hit Gulf buildup—Seattle rally draws 500, Seattle Times, p. A1.

Gragg, R. (1990, September 30) Protesting artists spill their feelings onto streets, The Oregonian, p. B1

Graves, B. (1990, December 11) Group threatens boycott of schools. The Oregonian, p. B1.

Graves, B., Hernandez, R. and M. Blackmaun (1997, June 17) District puts Jefferson teachers on notice. The Oregonian, p. A1.

Graves, B. Pickett, N. Richards, S. Heinz, S. and F. Church (1991, February 5)

Hundreds of students stay away from city's schools, The Oregonian, p. A1.

Groups Protest Editorial Cartoon, (1996, July 25) Seattle Times, p. B2. 
Guillen, T., Broom, J. Henderson, D. and Norton, D. (1991, January 17) Protesters shut down city's Federal Building. Seattle Times, p. A1.

Gupta, H. (1990, September 13) Marchers protest port contract-Minority business leaders say airport concessions pact blocks access, Seattle Times, p. B4.

Gupta, H. Strickland, D. Wieland Nogaki, S. (1992, May 2) Taking stock:

Downtown stores assess impact, Seattle Times, p. A5.

Haberstroh, J. (1991a, May 23) Activists 'live-in' apartment. Seattle, Times p. B1. Haberstroh, J. (1991b, June 6) Arion to become low-income housing. The Seattle Times, p. C1.

Haines, T. (1994a, September 12) Second rally on Broadway against police brutality is peaceful-Alleged police brutality protested, Seattle Times, p. B1.

Haines, T. (1994b, September 16) Broadway's homeless youth-Clash with police puts focus on Capitol Hill street kids, Seattle Times, p. B1.

Haines, T. (1995, February 6) Protesters sit-in to stand-up for homeless-advocates hope to free-up vacant hotel. The Seattle Times, p. B1.

Hatch, W. (1989, August 3) Anarchists-in-residence-Young squatters are leading housing revolt. The Seattle Times, p. G1.

Heinz, S. (1992, January 8) The homeless vigil at City Hall, The Oregonian, p. C1.

Heinz, S. (1996, March 30) 200 students say they're fed up with Portland school budget cuts," The Oregonian, p. A1.

Hernandez, R. (1996, April 5) Classes empty out in budget protests, The Oregonian, p. B2.

Hewitt, S. (1997, April 9) Education activists demand reform: Public school system fails all students, critics say. The Skanner, Portland edition, p. 1.

Hill, J. (1993, November 2) Workers at hotels press rights. The Oregonian, p. B14.

Ho, V. (1994, July 13) A sleep-in at City Hall-Plan to raze 'Jungle' protestedeclectic group of demonstrators snuggles in to back Beacon Hill encampment, Seattle Times, p. B3. 
Holmes, S. Acohido, B. and P. Routman (1995, December 14) Boeing workers back, in 'The spirit of '95'-Back on job, it looks same as 69 days ago, The Seattle Times, p. A1.

Hortsch, D. (1998, April 6) Residents wary about prospect of adult shops, The Oregonian, p. E2.

House, D. (1992, March) Activists fight God Squad. The Alliance, Vol. 12, 3, p. 4.

Housing protesters meet with owners (1991, May 22) Seattle Times, p. B2.

I-Chin Tu, J. (1996, October 23) Two arrested in downtown rallies, Seattle Times, p. B3.

Interview with Ron Herndon. (1991, Febraury 4, 6:33 p.m.) KATU News.

Ith, I. and J. Burkitt (1999, December 3) Rally protests police actions-Some question the use of rubber bullets, tear gas on bystanders in residential neighborhood, Seattle Times, p. A22.

Jacklett, B. (1998, October 19) Down on the corner. Willamette Week, p. 25.

Johnson, T. and Jones, C. (1994, April 27) Protesters spark discussion: Is Rose Festival objectification? The Clarion: Cleveland High School newspaper, p. 6.

Jung, H. (1994a, April1) Housing activists arrested at mayor's office. Seattle Times, p. B3.

Jung, H. (1994b, May 23) Sidewalk law spurs sit-ins downtown. Seattle Times, p. B1.

Kajihiro, K. (1994, October) HWOC Delivers 10,000 Voices to Justice and Safety. The Alliance, Vol. 14, 10, p. 4.

King, W. (1990, July 29) Pickets At Games Decry Boxing Violence. Seattle Times, p. A8.

Kiyomura, C. (1991, February 14) City Hall protesters urge keeping refugee aide position. The Oregonian, p. B2.

Kiyomura, C. (1992a, January 1) Homeless teens camp out in front of City Hall to contest policies. The Oregonian, p. C5. 
Kiyomura, C. (1992b, February 13) Minority Business Association chastises city over contracts. The Oregonian, p. B10.

Kossen, B. (2005, January 17) Bittersweet days in the Central Area; Seattle neighborhood with a rich cultural history is again changing, to mixed reviews, Seattle Times, p. E1.

Kuebelbeck, A. (1990, August 4) Groups of gays protest picnic, Seattle Times, p. A5.

Laatz, J. (1995, June 28) Rally urges Clinton to protect environment. The Oregonian, p. A11.

Lawson, L. (1992, April 22) Rice faces the wrath of 700 Central Area residents, The Skanner, p.1.

Leeson, F. (1990, February 9) Eight Abortion Foes Offered Jail Release. Oregonian, p. D1.

Lewis, P. (1990, April 1) No longer forced to hold their tongues-Harborview withdraws policy requiring workers to speak English only. Seattle Times, p. B8.

Lewis, P. (1991, February 17) Q-Patrol takes to the streets to stem gay-bashing. Seattle Times, p. B4.

Liljeholm, A. (1995, April 6) Letter to the editor. The Clarion: Cleveland High School newspaper, p. 7.

Lilly, D. (1989, October 20) 3 convicted of trespass in homeless protest. The Seattle Times, p. B3.

Lilly, D. (1992, March 24) Attack crime or harass teens?-Central Area groups protest Weed and Seed grant. Seattle Times, p. B3.

Lim, P. (1995, March 22) Pickets try to get their message out-Group Health nurses on one-day strike. Seattle Times, p. D1

Local radio DJs taken by surprise by Feminist Commandos. (1997, July) The Alliance, Vol. 17: 6, p. 14.

Lockhart, J. (1994, April) Remembering Anna Mae, The Alliance, p. 5.

Louey, S. (1991, July17) Holladay closures protested. The Oregonian, p. D5. 
Making a scene. (1990, September 20). Seattle Times, p. B1

Mann, E.J. (1990, June 17) Marching for South Africa-Seattle rally calls attention to tragedy of Soweto in 1976. Seattle Times, p. B2.

Manzano, P. (1990, September 26) Quayle protesters charge police used excessive force. The Oregonian, p. B8.

Mapes, J. (1991, September 18) The President in Portland: Another day in Beirut? The Oregonian, p. A1.

Marshall, R. (1992, Sept. 23) Groups say no to Weed and Seed, The Skanner, p. 3.

Marshall Wells, R. (1999, May 13) Red Apple fans organize a protest. Seattle Times, p. E11.

Martin, J. (1990, January 5) The homeless and the media: A look at reality on the streets. The Seattle Times, p. A7.

Maushard, L. (2007, November) Portland Jornaleros look to a city-supported day labor center opening in early 2008. The Alliance, Vol 27: 10, p.1.

Mayer, N. (1995, May 14) Women march to assert claim to a safer nighttime world. The Oregonian, p. C7.

Mazza, P. (1990, December 12) School boycott latest chapter in long fight. The Skanner, Portland Edition, p.1.

McDermott, J. (1992, January 19) Gimme shelter. The Oregonian, p. C3.

McDermott, T. (1993, May 2) NAFTA 'free trade' not 'fair' protesters at Westlake Center say. Seattle Times, p. B4.

McFarland, M. (1999, July 5) Gay-rights activists will target KCTS-TV—program line up draws protest. Seattle Times, p. B1

McIntosh, D. (1999, August) Unionists take Freedom Tour. The Alliance, Vol.19,:8, p. 1 .

Mc Nichol, B. (1993, March 21) American Indians protest at celebration. The Oregonian, p. C2. 
Meehan, B. (1990, December 14) Group gives reasons for boycott. The Oregonian, p. A4.

Merritt, M. (1992, December 15) Amid protest, council o.k.'s Weed and Seed:

Federal funds target Central crime area. Seattle Post-Intelligencer, p. B1.

Nelson, R.T. (1990, June, 22) Prospect worse for low-cost housing - Council finds no legal way to act, Seattle Times, p. E3.

Njubi, F. (1993, May 19) Weed and Seed proposals due. The Skanner, p. 1.

Norton, D. (1996, March 15) City shrubbery pulled out to make room for bedrolls11 arrested at Municipal Building's homeless camp. Seattle Times, p. B3.

Norton, D. and Birkland, D. (1992, May19) Leniency urged in violent protests. Seattle Times, p. B2.

Nkrumah, W. (1997, April 7) Angry group of St. Johns folks talks secession. The Oregonian, p. B2.

Nkrumah, W. (2006, July 13) Famed in the ring, he hit injustice harder, The Oregonian, p. C6.

Oliver, G. (1990, July 10) Children's Services caseworkers protest heavy workload. Oregonian, p.D15.

Oliver, G. (1991, December 16) Gay group attends service in protest. The Oregonian, p. B4.

Once-chilly tenants find it pays to protest. (1990, December 13). Seattle Times, p. E3.

Opal Creek demonstration draws 2000 to Pioneer Square. (1994/5, December/January) The Alliance, p. 4.

Parker, T. (1997, December 10) Anti-gang advocates to march on City Hall: Gang intervention rally and play planned to Pioneer Square cancelled, The Skanner, Portland Edition, p. 1.

Parker, T. (1999, September 1) Gathering mobilizes teams at targeted schools: Meeting of principals, district leaders and parents called historic. The Skanner, Portland Edition, p.1.

Peterson, J. (1998, July 13) Tenants protest increase in rent-City councilman says jump illustrates housing crisis here. Seattle Times, p. B1. 
Phelps, C. (1990, August) Portland grocers lock out workers. The Alliance, Vol. 10, 8, p. 13.

Pickett, N. (1990, January 31) Protest of adult bookstore proves small, brief. The Oregonian, p. D2.

Plank, J. (1990a, March 18) Activists mourn the end of McKay-Apartments razed; deal termed vad victory, Seattle Times, p. B1.

Plank, J. (1990b, July 24) Billboards commandeered to advertise dissent-Arena foes deface Ackerley-owned signs. Seattle Times, p. A1.

Postman, D. Broom, J. and W. King (1999, November 30) Clashes and protests force cancellation of WTO opening event. Seattle Times, p. A1.

Postman, D. and Mapes, L. (1999, December 6) Despite riots WTO opponents left Seattle with some successes, Seattle Times, p. A1.

Praise for So Many. (1992, May 6) The Oregonian, p. D12.

Pratt, C. (1995, October 9) Police sweep homeless out at Ross Island Bridge. The Oregonian, p. B1

Protest at Northwest Hospital (1999, January 3) Seattle Times, p. B2.

Rivero, I. (1998, May) Excessive force: Worker advocates denounce tactics in INS raid. The Alliance, Vol. 18, 4, p. 1.

Robin, J. (1999, November 25) Taxi union urges cabbies to strike first day of WTO. Seattle Times, p. A22.

Rollins, M. (1990, June 13) Anti-racists protest in front of home. The Oregonian, p. C5.

Rollins, M. (1991, May 5) White supremacists stage rally. The Oregonian, p. D1.

Rose, C. (1999, June 15) Artists protest captures lost faces of Project 416. Seattle Times, p. F3.

Rubenstein, S. (1991, July 9) Gay rights backers disrupt alliance meeting. The Oregonian, p. B3. 
Santana, J. (1998, January 21) Police hope to "weed" crime from valley. The Skanner, Seattle Edition, p. 1.

Schedule of APEC Events. (1993, November 18) Seattle Times, p. A22.

Scott, J. (1998, January 19) Abortion supporters picket church. The Oregonian, pg. E2.

Shatzkin, K. (1992, September, 22) Housing activists occupy vacant Seattle hotelBuilding owner, Seafirst to talk with protesters. The Seattle Times, p. B4.

Snell, J. and Anderson, D. (1997, July 10) INS raids job corner on NE Burnside. The Oregonian, p. D2.

Snell, J. Rollins, M. Gilbert, H. and Manzano, P. (1990, October 8) 1500 rally against prejudice. The Oregonian, p. Al.

Spicer, O. (1994, October 17) Lloyd area anti-meter fever mounting. The Oregonian, p. B2.

Stacey, H. (1995, April 6) Men don't need to be part of it. The Cleveland Clarion, p. 6.

Steele, J. (1994, July 31) Mt. Scott-Arleta residents protest lingerie modeling business. The Oregonian, p. C5.

Stewart, B. (1996, January 13) Kids project replaces Rose Festival Junior Court, The Oregonian, A1.

Stewart, B. (1998, July31) Protesters march for all-night bus run. The Oregonian, p. C2.

Stricherz, V. (1990, July 4) Rice's drug loitering law protested-But mayor won't reply until Friday. Seattle Times, p. D2.

Strickland, D. (1992, February 9) Blacks give Nordstrom dubious award. Seattle Times, p. B1.

Students charging racism burn campus newspapers (1992, March 14) Seattle Times, p. A18.

Students discuss boycott. (1991, February 1, 10:31 p.m.) KPTV 12 News. 
Sullivan, J.and Read, R. (2000, September 20) INS' Beebe Leaves, The Oregonian, p. A1.

Sullivan, R. (1994, July 4) Thorny. The New Republic, p. 9-10.

Sundvall, J. (1996, June/July) Workers Organizing Committee puts a thorn in Allen's Rose Garden. The Alliance, Vol. 16, 6, p. 5.

Task force to study school quality. (1991, January 30, 12:08 p.m.) KXL AM Radio. Taylor, C. (1991, May 24) Police clear building - Homeless evicted-4-day occupation of building kindles ideas on housing. The Seattle Times, p. C1.

Taylor, C. Brown, C. and J. Simon (1991, January 18) Gathering for peace-Seattle vigil attracts 2,000. Seattle Times, p. A8

Tongue, K. (1997, July 3 ) The struggle to work. The Oregonian, p. O1.

Valvadere, M. (1994, January 26) Drug sting nets 20 non-are residents. The Skanner, p.1.

Wee, E. (1993, March 14) Neighbors picket against Powell adult motel. The Oregonian, p. C11.

West Seattle mini-mart becomes target of protests. (1996, October 2) Seattle Times, p. D1.

Williams, M. and Haberstroh, J. (1992, January 27) Capitol Hill protest turns ugly14 arrested as march by 400 turns violent. Seattle Times, p. E1.

Winfield, P. (1990, January 25) A protest to keep Publix Hotel open-The weak voice of the homeless, Seattle Times, p. B3.

\section{Scholarship}

Abbott, C. (1992) Regional city and network city: Portland and Seattle in the twentieth century. The Western Historical Quarterly, 23:3, 293-322.

Alinsky, S. (1971) Rules for radicals: A practical primer for realistic radicals. New York: Random House.

Auyero, J. (2003a) Relational riot: austerity and corruption protest in the neoliberal era, Social Movement Studies, 7:7, 117-145. 
Auyero, J. (2003b) Contentious lives: Two Argentine women, Two protests and the quest for recognition. Durham, N.C.: Duke University Press.

Auyero, J. (2007) Routine politics and violence in Argentina: The gray zone of state power. Cambridge/New York: Cambridge University Press.

Banks, E. (2000) Think locally, act globally. Social Policy, 30: 3, 66-90.

Bartholomew, A. and Mayer, M. (1992) Nomads of the present: Melucci's contribution to 'new social movement' theories. Theory, Culture and Society, 9:4, 141-159.

Bayat, A. (1997) Street politics: Poor people's movements in Iran. New York: Columbia University Press.

Berry, J. Portney, K. and K. Thomson (1993) The rebirth of urban democracy. Washington D.C.: The Brookings Institute.

Brand, U. and M. Wissen (2005) Neoliberal globalization and the internationalization of protest. Antipode, 37: 1, 9-17.

Brenner, N. (2001) Limits to scale? Progress in Human Geography, 25:4, 591-614.

Bronfenbrenner, K, Friedman, S. Hurd, R. Oswald, R. and R. Seeber (1998)

Organizing to win: New research on union strategies. Ithaca/London: Cornell University Press.

Castells, M. (1977). The urban question: A Marxist approach. Cambridge: MIT Press.

Castells, M. (1983). The city and the grassroots: $A$ cross-cultural theory of urban social movements. Berkeley: University of California Press.

Castells, M. (2006) Changer la ville: A rejoinder, International Journal of Urban and Regional Research, 30:1, 219-223.

Cervantes-Gautschi, P. (2005) Challenges to organizing low-wage workers. Retrieved 11/30/2007, from http://www.enlaceintl.org/wa/enlace/ei/103.

Clemens, E. and Hughes, M. (2002) Recovery of protest: Historical research in social movements. In B. Klandermans and S. Staggenborg, (Eds.) Methods of Social Movement Research (pp. 201-230). Minneapolis: University of Minnesota Press. 
Collins, J. (2000) A sense of possibility. NACLA report on the Americas, 33:5, 4049.

Davis, J. (2002) Stories of change: Narratives in social movements. Albany: SUNY Press.

Davis, M. (1990) City of Quartz: Excavating the Future in Los Angeles. London: Verso.

DeFillipis, J. and North, P. (2004) The emancipatory community? Place politics and collective action in cities. In L. Lees (ed.) The emancipatory city: paradoxes and possibilities (pp. 72-88). Thousand Oaks, London and New Delhi: Sage publications.

DeLeon, R. (1992) Left coast city: Progressive politics in San Francisco, 1975-1991. Lawrence, KS: University of Kansas Press.

Della Porta, D. and M. Diani. (1999) Social movements: An introduction. Oxford: Blackwell.

Della Porta, D. and Tarrow, S. (2006) Globalization from below: Transnational activists and protest networks. Minneapolis: University of Minnesota Press.

Della Porta, D. and Mosca, L. (2007). In movimento 'contamination' in action in the Italian global justice movement. Global Networks, 7, 1, 1-27.

Diers, J. (2004) Neighbor power: Building community the Seattle way. Seattle: University of Washington Press.

Durbin, K. (1996) Tree huggers: Victory, defeat and renewal in the Northwest Ancient Forests Campaign. Seattle: The Mountaineers Press.

Edelman, M. (2001) Social Movements: changing paradigms and forms of politics, Annual Review of Anthropology, 30: 285-317.

Fainstein, S. and Fainstein, N. (1974). Urban political movements: The search for power by minority groups in American cities. Englewood Cliffs, N.J.: Prentice-Hall.

Fantasia, R. (1988) Cultures of solidarity: Consciousness, action and contemporary American workers. Berkeley: University of California Press.

Flyvbjerg, B. (2006) Five misunderstandings about case studies. Qualitative Inquiry, 12: 219-247. 
Fontan, J. Hamel, P. Morin, R. and Shragge, E. (2007). Social movements raising environmental and social justice issues. How is the city taken into account? Paper presented at the Urban Affairs Association Annual Meeting, Seattle, Washington.

Gans, H. (1962) The urban villagers: Group and class in the lives of Italian Americans. New York: Free Press.

Gibson, K. (2007) Bleeding Albina: A history of community disinvestment, 19402000. Transforming Anthropology, 15:1, 3-25.

Gibson, T. (2004) Securing the spectacular city: The politics of revitalization and homelessness in downtown Seattle. Lanham, MD: Lexington Press.

Giugni, M. (1999) How social movements matter: Past research, present problems and future debates. In M. Giugni, D. McAdam and C. Tilly (eds.) How Social Movements Matter (pp. xi-xxxiii). Minneapolis: University of Minnesota Press.

Harvey, D. (1996) Justice, nature and the geography of difference. Lanham, MD: Blackwell.

Katznelson, I. (1981). City trenches: urban politics and patterning of class in the United States. New York: Pantheon.

Kirby, A. (1993) Power/resistance: local politics and the chaotic state. Bloomington/Indianapolis: Indiana University Press.

Koopmans, R. and D. Rucht. (2002). Protest event analysis. In B. Klandermans and S. Staggenborg, (Eds.) Methods of Social Movement Research (pp. 231-259). Minneapolis: University of Minnesota Press.

Lagner, E. (2003) One hundred little Hitlers: The death of a black man, the trial of a white racist and the rise of the neo-Nazi movement in America. New York:

Metropolitan Books.

Lake, R. (2006) Recentering the city. International Journal of Urban and Regional Research 30:1 194-197

Leavitt, J. and Saegert, S. (1984). Women and abandoned buildings: A feminist approach to housing, Social Policy, Spring, 32-39.

Lefebvre, H. (1991). The production of space (D. Nicholson-Smith, Trans.) Oxford: Blackwell. 
Lefebvre, H. (1996) Writings on cities (E. Kofman and E. Lebas, Trans.) Oxford: Blackwell.

Lefebvre, H. (2005a) Critique of everyday life, Volume I(J. Moore, Trans.). London/New York: Verso.

Lefebvre, H. (2005b) Critique of everyday life, Volume II (J. Moore, Trans.). London/New York: Verso.

Lefebvre, H. (2005c) Critique of everyday life, Volume I(J. Moore, Trans.). London/New York: Verso.

Lowe, S. (1986) Urban social movements: The city after Castells. New York: St. Martins' Press.

Lyons, J. (2004) Selling Seattle: Representing contemporary urban America. London/New York: Wallflower Books.

MacDonald, B. (2006) Performing Marx: Contemporary negotiations of a living tradition. Albany: State University of New York Press.

Marston, S.A. (2000) The social constructs of scale, Progress in Human Geography, $24: 2,219-212$.

Marston, S.A. and Smith, N. (2001) States, scales and households: Limits to scale thinking? A response to Brenner, Progress in Human Geography, 25:4, 615-619.

Martinotti, G. (1999) A city for whom? Transients and public life in the second generation metropolis. In S. Body-Gendrot and R. Beauregard (eds.) The urban moment: cosmopolitan essays on the late- $20^{\text {th }}$ century city. Thousand Oaks: Sage Publications.

Massey, D. (1994) Space, place and gender. Cambridge: Polity Press.

Mayer. M. (2000) Urban social movements in an era of globalization. In P. Hamel, H. Lustiger-Thaler and M. Mayer (Eds.) Urban Movements in a Globalizing World (pp. 141-157). London: Routledge.

Mayer, M. (2003) The onward sweep of social capital: Causes and consequences for understanding cities, communities and urban movements. International Journal of Urban and Regional Research, 27:1, 110-132. 
Mayer, M. (2006) Manuel Castells' The city and the Grassroots. International Journal of Urban and Regional Research 30:1, 202-206.

McAdam, D. (1982) Political process and the development of black insurgency: 1930-1970. Chicago: University of Chicago Press.

McAdam, D. (1983) Tactical innovation and the pace of insurgency, American Sociological Review, 48: 735-754.

McAdam, D. (1999) The biographical impact of activism. In M. Giugni, D. McAdam and C. Tilly (eds.) How Social Movements Matter (pp. 119-148). Minneapolis: University of Minnesota Press.

McCarthy, J.D. McPhail, C. and J. Smith (1996) Media bias in the coverage of Washington D.C. demonstrations. American Sociological Review, 61: 478-499.

McLagan, E. (1980) A peculiar paradise: A history of blacks in Oregon 1788-1940. Portland: Georgian Press.

Melucci, A. (1989) Nomads of the present: Social movements and individual needs in contemporary society. Philadelphia: Temple University Press.

Merrifield, A. (2002) Dialectical urbanism. New York: Monthly Review Press.

Miller, B. (2006). Castells' The City and the Grassroots: 1983 and today. International Journal of Urban and Regional Research, 30:1, 207-211.

Minkoff, D.C. (1997) The sequencing of social movements. American Sociological Review, 62, 5, 779-799.

Mitchell, D. (2003) The right to the city: Social justice and the fight for public space. New York: The Guillford Press.

Molotch, H. (1984) Romantic Marxism: love is (Still) not enough. Contemporary Sociology, 13:2, 141-143.

Moody, F. (2003) Seattle and the demons of ambition: From boom to bust in the number one city of the future. New York: St. Martin's Griffin.

Nicholls, W. and Beaumont, J. (2004) The urbanization of justice movements? Possibilities and constraints for the city as a space of contentious struggle, Space and Polity, 8: 2, 119-135. 
Olds, K. (2001) Globalization and urban change: Capital, culture and Pacific-Rim Mega-projects. Oxford/New York: Oxford University Press.

Olsen, M. (1963) The logics of collective action. Cambridge, MA: Harvard University Press.

Ozawa, C. (2004) The Portland edge: Challenges and success in a growing community. Washington: Island Press.

Pickerall, J. and Chatteron, P. (2006) Notes towards autonomous geographies: Creation, resistance and self-management as survival tactics. Progress in Human Geography, 30: 6, 730-746.

Pickvance C. (1976) On the study of urban social movements. In C. Pickvance (Ed.), Urban Sociology: Critical Essays (pp.198-218). New York: St. Martin's Press.

Pickvance, C. (2003) From urban social movements to urban movements: A review and introduction to a symposium on urban movements. International Journal of Urban and Regional Research, 27:1, 102-109.

Piven, F. and Cloward, R. (1979). Poor people's movements: Why they succeed, how they fail. New York: Pantheon Books.

Piven , F. and Cloward, R. (1991) Collective protest: A critique of Resource Mobilization theory, International Journal of Politics, Culture and Society, 4:4, 435458.

Polletta, F. (1998a) It was like a wave: Narrative and identity in social movements. Social Problems, 40:2, 137-159.

Polletta, F. (1998b) Contending stories: Narrative in social movements. Qualitative Sociology, 21:4, 419-446.

Polletta, F. (2002) Freedom is an endless meeting: Democracy in American social movements. Chicago: University of Chicago Press.

Pred, A. (1986) Place, practice and structure. Cambridge: Cambridge University Press.

Roberts, J. (2006) Philosophizing the everyday: Revolutionary praxis and the fate of cultural theory. London/Ann Arbor, MI: Pluto Press. 
Sassen, S. (1991). Global city: Tokyo, New York, London. Princeton: Princeton University Press.

Savage, L. (2006) Justice for Janitors: Scales of organizing and representing workers. Antipode, 38:3, 645-666.

Sheringham, M. (2006) Everyday life: Theories and practices from Surrealism to the present. Oxford/New York: Oxford University Press.

Smith, N. (1996) The new urban frontier: Gentrification and the revanchist city. London/New York: Routledge.

Snow, D. and Trom, D. (2002) The case study and social movements. In B. Klandermans and S. Staggenborg, (Eds.) Methods of Social Movement Research (pp. 146-172). Minneapolis: University of Minnesota Press.

Stoecker, R. (1991) Evaluating and rethinking the case study. The Sociological Review, 39:1, 88-112.

Tarrow, S. (1989) Democracy and disorder: Protest and politics in Italy. New York: Oxford University Press.

Tarrow, S. (1994) Power in movement: Social movements, collective action and politics. New York/Cambridge: Cambridge University Press.

Taylor, Q. (1994) The forging of a black community: Seattle's Central District from 1870 through the civil rights era. Seattle/London: University of Washington Press.

Taylor, Q. (2007) There was no better place to go: African-American migration, 1940-1950. In D. Stratton (ed.) Terra Northwest: Interpreting People and Place. Pullman, WA: Washington State University Press.

Tilly, C. Tilly, L. and R. Tilly (1975) The rebellious century, 1830-1930. Cambridge, MA: Harvard University Press.

Tilly, C. (1986) The Contentious French. Cambridge, MA: Harvard University Press.

Tilly, C. (1999) From interaction to outcomes in social movements. In M. Giugni, D. McAdam and C. Tilly (eds.) How Social Movements Matter (pp. 253-270).

Minneapolis: University of Minnesota Press.

Tilly, C. (2004). Social movements: 1768-2004. Boulder: Paradigm Publishers. 
Touraine, A. (1988). The return of the actor: Social theory in post-industrial society. Minneapolis: University of Minnesota Press.

Turner, R. H. and Killian, L. (1987). Collective behavior, Third Edition. Englewood Cliffs, N.J.: Prentice Hall.

Wagner, D. (1993) Checkerboard Square: Culture and resistance in a homeless community. Boulder: Westview.

Wilson, J.Q. (1973) Political organizations. New York: Basic Books.

Yin, R. (1984) Case Study Research. Beverley Hills, CA: Sage.

\section{Archival Documents}

Bernard, L. Memo to S. Cruz, Re: Day Laborers' Project, July 22, 1997, Box 300110, Day Labor Project, Archival Folder 08-02-30, Stanley Parr Archives and Records Center.

Day Laborer's Program, 1998, Box 300-10, Living Wage, Archival Folder 12-05-24, Stanley Parr Archives and Records Center.

Holloway, Arnette, March 23, 1992a, Press Release: Groups Unite to Fight Police State in Central Area, Box 21/9, Weed and Seed Documents, Record Series 5272-08, Seattle Municipal Archives.

Holloway, Arnette correspondence to Mayor Norm Rice, November 17, 1992b, Box 20/5, Weed and Seed Documents, Record Series 4667-02, Seattle Municipal Archives.

Mothers Against Police Harassment Newsletter, December, 1992, Box 20/5, Weed and Seed Documents, Record Series 4667-02, Seattle Municipal Archives.

Public Safety Technical Advisory Committee Meeting Notes, March 7, 2000, Box 241/17, Public Safety Sub-Committee, Record Series 4603-01, Seattle Municipal Archives.

Rahsaan, H. letter to Portland Public School Board, May 8, 1997, Regular School Board Meeting Minutes, 1997, Portland Public School Archives.

Seattle Police Department Memo from Captain B.E. Wingstead, April 27, 1994, Box 21/9, Public Safety Sub-Committee, Record Series 5272-08, Seattle Municipal Archives. 
Special Task Force of Educational Improvements (1991, June 27) Report of Special Task Force of Educational Improvements. Portland: Portland Public Schools.

Sten, E., Kafoury, G. and Francesconi, J. Memo to V. Katz and C. Hales, Re: Fair Wage Ordinance, March 20, 1998a, Box 300-10, Living Wage, Archival Folder 1205-24, Stanley Parr Archives and Records Center

Sten, E. Memo to V. Katz, J. Francesconi, C. Hales and G. Kafoury, Re: Central Eastside Day Labor Situation, November 16, 1998b, Box 300-10, Living Wage, Archival Folder 12-05-24, Stanley Parr Archives and Records Center.

12-Point Educational Improvement Plan, January, 1990, Box 5801-1000-01, AfricanAmerican School Performance, Archival Folder 02-03-52, Stanley Parr Archives and Records Center.

Weed and Seed Fact Sheet, 1992, Box 21/9, Record Series 5272-08, Weed and Seed Documents, Seattle Municipal Archives.

\section{Personal Communications}

Cervantes-Gautschi, Peter, Hotel Workers' Organizing Committee, Director, Interviewed on January 24, 2008, 9:00 a.m.

Fox, John, Seattle Displacement Coalition, Coordinator, Interviewed on April 4, 2008, 11:45 a.m.

Herndon, Ron, Black United Front, Chairperson, Interviewed on March 12, 2008, 10:00 p.m.

Hunter-Morton, Ismoon, Cleveland High School Protest Organizer, Interviewed on May, 2, 2008, 7:15 p.m.

Walden, Harriet, Mothers Against Police Harassment, Co-Founder, Interviewed on April 7, 2008, 4:00 p.m.

Williams, Jeri, Workers' Organizing Committee, Organizer, Interviewed on February 5, 2008, 10:00 a.m. 


\section{APPENDIX \\ PROTEST EVENT ANALYSIS DATA: \\ URBAN PROTESTS}

\section{Labor}

\begin{tabular}{|c|c|c|c|c|c|c|c|c|}
\hline Toplc & Polttes & Size & Target & ractics & Police & Clty & Participants & R to City or Cause \\
\hline enviro & 1 & 50 & McDonalds & picke! & 0 & 2 & OSPIRG & ban styrofoam in city \\
\hline labor & 1 & 100 & CSD mgmt. & demo & 0 & 2 & CSD workers & workload too much \\
\hline labor & 1 & 6000 & Kenows & strikefocko & 0 & 2 & UFCW & grocery wrks right strike \\
\hline rece & 1 & 30 & city hall & rally & 0 & 2 & NAMCO & hire minority firms \\
\hline labor & 1 & 100 & Yeon Bldg. & rally & 0 & 2 & SEIU 503 & justlce for janitors \\
\hline labor & 1 & & Food 4 Less & picket & 0 & 1 & JWJ & honor wkrs union \\
\hline labor & 1 & 24 & Local 296 shipyard & rally & 0 & 2 & workers & object to dues raise \\
\hline racism & 1 & 20 & FHA & rallymarch & 0 & 2 & NAMCOIJWJ & hire minority fims \\
\hline labor & 1 & & PG\&E & picket & 0 & 2 & workers & no job change/safety \\
\hline labor & 1 & 100 & merrill lynch & rally & 1 & 2 & teansters & ralse and better wkg cond \\
\hline labor & 1 & 120 & hotels & rally & 0 & 2 & HERE & recogrition vote rally \\
\hline laborieduc & 1 & & school board & pick/demo & 0 & 2 & leachers & give us a contract \\
\hline labor & 1 & 100 & OHSU Bof Dir. & picket & 0 & 2 & Nurse Union & give nurses respect \\
\hline labor & 1 & 200 & Alen/whitsett office & sit-in rally & 1 & 2 & wos & no toxics Red Lon Wkrs \\
\hline labor & 1 & 10 & Nalto Co. & quit & 0 & 2 & managers & no downsizing \\
\hline race & 1 & & PDC & proles & 0 & 2 & NAMCO & hire minority fims \\
\hline immigfabor & 1 & & INS & pressconf & 0 & 2 & woc & treat immig wrk respect \\
\hline labor & 1 & 30 & dity council & protest & 0 & 2 & scanel letter & repeal sex worker lisc. \\
\hline labor & 1 & 75 & airport & freetour & 0 & 2 & SEIU & workers struggle visible \\
\hline \multicolumn{9}{|l|}{ SEATTLE } \\
\hline labor & 1 & 60 & rallyloccupy & west s hosp & 2 & 1 & nurse/staff & back pay and benefits \\
\hline race & 1 & 15 & march & Seatac & 2 & 0 & core, NWblEus & subcontract to bi. Busi \\
\hline labor & 1 & & rally & bus tunnel & 2 & 0 & electrians & make benefit payments \\
\hline race & 1 & 200 & rally/march & Norćstrom & 2 & 0 & bl dollar days & fair hiring/s to bl. Busi \\
\hline race & 1 & & rally & $\mathrm{CD}$ & 2 & 0 & Bi\$DaysTaskF & support bl. Own busines \\
\hline marjuana & 1 & 7 & picket & Hydro Tech & 2 & 0 & NORML & no drug war \\
\hline labor & 1 & & march & Mayors & 2 & 0 & Pike PI Merch & no sales to big vendors \\
\hline labor & 1 & 1500 & rally/march & Swed med & 2 & 0 & SEIU & fair contract \\
\hline labor & 1 & & rally/march & Swed med & 2 & 0 & SEIU & no layoffs \\
\hline labor & 1 & 1400 & strike & Group Health & 2 & 0 & Nurses & Fair contract, pat load \\
\hline labor & 1 & 50 & action & UWGrad & 2 & 0 & CSAL925 & fair contract staff \\
\hline labor & 1 & & rally/action & mini mart & 2 & 1 & MW & support strikers \\
\hline labor & 1 & & rally & Sth theatre & 2 & 0 & Music Union & better wages \\
\hline labor & 1 & 60 & rallyistrike & Sth theatre & 2 & 0 & Music Union & better wages \\
\hline labor & 1 & 650 & rally/strike & 5 th theatre & 2 & 0 & Unions & support music/shut down \\
\hline educ/sports & 1 & & rally & cleveland & 2 & 0 & parents & support footto all coach \\
\hline labor & 1 & 200 & strike & Fike PI Mki & 2 & 0 & craftspeople & no spate changes \\
\hline labor & 1 & 50 & roving blk & downtown & 2 & 0 & cabbies & equal regs with town car \\
\hline labor & 1 & 36 & disruption & cividtopera & 2 & 0 & musicians un & recognize union \\
\hline
\end{tabular}




$\begin{array}{lllllllll}\text { labor } & 1 & 70 & \text { sickoutrally } & \text { Garfield } & 2 & 0 & \text { teachers } & \text { pay raiset } \\ \text { arts } & 1 & 80 & \text { picket } & \text { OTB } & 2 & 0 & \text { artistsidancer rehire mark murphy } \\ \text { labor } & 1 & 600 & \text { strike } & \text { DT } & 2 & 0 & \text { taxi alliance } & \text { no ord against taxis }\end{array}$

\section{Neighborhood}

\begin{tabular}{|c|c|c|c|c|c|c|c|c|}
\hline Tople & Polltics & S1:0 & Target & Tactics & Police & Gity & Participants & $\mathbf{R}$ to City or Causo \\
\hline nbhd & 2 & 4 & adult bookstore & pickat & 0 & 2 & Haw Bus. Asc. & business idea of nohd. \\
\hline nbhd. & 2 & 75 & Burger King & rally & 0 & 2 & nbd. Assc. & no burger king in nbhd. \\
\hline racism & 1 & & Bill's Kwik Mart & rally & 0 & 2 & comm grps & man kllied by bouncer \\
\hline mbhd. & 2 & 40 & city hali & rally & 0 & 2 & POP & cul costs of sever hookup \\
\hline health/nbhd & 2 & & Holladay Park Med & picket & 0 & 2 & caraloga terr & don't shut hosipital \\
\hline nbho: & 2 & 12 & nuhd. Vidence & vigin & 0 & 2 & neigh. & no more shootings \\
\hline nbhd. & 2 & 150 & gang vidence & rally/march & 0 & 2 & church, comm & no gang violence \\
\hline nohd & 2 & 40 & Powell Adult motel & picket & 0 & 2 & SE Uplift & protest motel repe \\
\hline nbhd & 2 & 12 & Powell Adult motel & picket & 0 & 2 & nohd. & close motel \\
\hline nohd. & 2 & 50 & Gentleman's Tan & relly & 0 & 2 & nbhd & no adutt business in nbhd \\
\hline nohd. & 2 & & transp pian/city & banner & 0 & 2 & Nohd/ousi & no parking meters in nbd \\
\hline nohd. & 2 & & traffic in Sellwood & rally & 0 & 2 & nelghbors & stop speeding resid sts. \\
\hline nohd. & 2 & 80 & Mult Co dept of cor & plcket & 0 & 2 & neighbors & no parde office nr RHS. \\
\hline nohd. & 2 & 24 & St Johns parole off & march & 0 & 2 & neighbors & too near school, no input \\
\hline public safety & 082 & & Fennern-sex offend & vandalism & 0 & 2 & brentdart nbers & no sex offender in nond. \\
\hline parks & 2 & 100 & selling parks & rally & 0 & 2 & nbho. & don't seil off park land \\
\hline nohd. & 2 & & Mult Co. Parde office & pickets & 0 & 2 & SNAFU & no parde of in St. Johns \\
\hline nbhd. & 2 & & City & secede talk & 0 & 2 & St. Johns NA & Nbhd. Not represented \\
\hline nond. & 1 & 50 & city, violence & marchurally & 0 & 2 & churches & no more violence \\
\hline nbhd & 2 & & porn shop & prolest & 0 & 2 & clara vista & no porn shops in nohd \\
\hline education & 1 & & PPS & meeting & 0 & 2 & New Party & no school closures in NE \\
\hline nohd & 2 & & Caste Superstore & picket & 0 & 2 & Siege & no more sex shops Barb. \\
\hline nbho & 2 & & moving billboard & picket & 0 & 2 & Seliwood & no animated billboards \\
\hline \multicolumn{9}{|l|}{ SEATTLE } \\
\hline nibhd. & 2 & 70 & rally & CD Apt. & 2 & 0 & Crri Nbhd Assn & evict ding dealers \\
\hline nohd. & 2 & 50 & rally/clean & 25thSLane & 2 & 0 & Judkins Com & get drugs out of comm \\
\hline gayfestian & 1 & 300 & march & Vol Park & 2 & 0 & AUUTFAFISnW & no Christ picnic \\
\hline nohd. & 2 & 9 & leaflet & Wsi Pt Sew & 2 & 0 & Magnolia & no sewage pl expansion \\
\hline nbhd. & 2 & & rallyimarch & 2nd Ave & 2 & 0 & denny regrade & Take back the streets \\
\hline gaylesbian & 1 & 7 & patrol & capitot hill & 2 & 0 & Qpatrol & no gay bashing \\
\hline race/police & 1 & 25 & march & city hall & 2 & 0 & co comm. & no Weed and Seed \\
\hline nbrind & 1 & 50 & rallyimarch & ganfield park & 2 & 0 & CACAg.Drugs & drugs/gangs out of $C D$ \\
\hline nbrhd & * & 15 & raily & port of seatt & 2 & 0 & Eastlake & no aimort noise \\
\hline race & 1 & 35 & picket & Sonics & 2 & 0 & Orgafamunity & Sonics support Bl. Com \\
\hline nbhd & 1 & 48 & march & south seattle & 2 & 0 & Rainbow Coal & Redaim Nbhd, no violen. \\
\hline nohd & 1 & 200 & rally/march & high point & 2 & 0 & high pl residen & stop the violence \\
\hline race & $t$ & & cccupation & colman sch & 2 & 0 & eat debnam & black history museum \\
\hline race & 1 & 50 & pkthoycolt & ColCitystwy & 2 & 0 & BI SDaystForc & stop killing shoppers \\
\hline nohd & 2 & 20 & rally & US West & 2 & 0 & Ravenna nor & No antenna \\
\hline race & 1 & 200 & ralyfmarch & oscars & 2 & 0 & nohd & no dneg abatement laws \\
\hline nbhd & 1 & 30 & picket & MW hospital & 2 & 0 & nibrs & no med wst incinerator \\
\hline
\end{tabular}




$\begin{array}{lrrllllll}\text { nbhd } & 2 & 200 & \text { rally } & \text { red apple } & 2 & 0 & \text { wedgewood nb } & \text { save red apple store } \\ \text { nbhd } & 2 & 300 & \text { rally } & \text { red apple } & 2 & 0 & \text { wedgewood nb save red apple store } \\ \text { racelciass } & 1 & 50 & \text { car rally } & \text { rainier valley } & 2 & 0 & \text { save our valley no rail line on MLK } \\ \text { tradejpolice } & 1 & 35000 & \text { riot } & \text { DT/Cap Hill } & 182 & 1 & \text { all/CH resident no Wro, no martial law } \\ \text { police } & 1 & & \text { rally } & \text { SCCC } & 2 & 0 & \text { nbho } & \text { no police state }\end{array}$

\section{Collective Consumption}

\begin{tabular}{|c|c|c|c|c|c|c|c|c|}
\hline Tople & Politics & Slze & Target & Tactics & Pollice & Cily & Particlpants & $R$ to Chy or Cause \\
\hline transport. & 2 & & city nal//PDC & rally & 0 & 2 & rall advocates & don't remove tracks \\
\hline raceleduc. & 1 & 40 & PPS & boycott mig & 0 & 2 & BUF & equal opp for black stdts. \\
\hline nousing & 1 & 12 & city & camp & 1 & 2 & Noman King & want city campground \\
\hline raceleduc & 1 & & PPS & press conf & 0 & 2 & BUF & adopt 12 point plan \\
\hline raceleduc & 1 & 24 & PPS & picket & 0 & 2 & Ralnbowy & meeting BUFIPPS bd. \\
\hline raceleduc & 1 & 18 & PPS & news conf & 0 & 2 & students & PPS students boycott \\
\hline race/educ & 1 & 5200 & PpS & boycot & 0 & 2 & students & BUF plan adopt \\
\hline public safe & 2 & 60 & Mult Co Measure 5 & rally & 0 & 2 & Com Pub Safe & No cuts to jails Meas 5 \\
\hline imm rights & 2 & 75 & city nall & rally & 0 & 2 & refugee forum & keep refugee aide pos. \\
\hline eduçation & 1 & 100 & PPS & rally & 0 & 2 & Grant & no steff cuts \\
\hline child care & 1 & 250 & eity/ety/st & rally & 0 & 2 & Corts Coal & support Quality child care \\
\hline housing & 1 & 25 & Oty Han & camp out & 1 & 2 & hml youth & youth housing \\
\hline housing & 1 & 100 & Measure 5 & parade & 0 & 2 & burnside/hl & no cuts to housing prog \\
\hline educ. & 1 & 200 & PPS & rally/march & 0 & 2 & Hoflyrood & save school from closure \\
\hline educ. & 1 & 3000 & Measure 5 & rally/march & 0 & 2 & Orfor Edu & not school cuts prop tax \\
\hline educ. & 1 & & bd. Of higher ed & news conf & 0 & 2 & PSU & no tuition increase \\
\hline race/educ & 1 & 70 & PPS & march & 0 & 2 & Wilson & protest move min, adv. \\
\hline raceleduc & 1 & 120 & Wison & gievance & 0 & 2 & students & no racism at Wilson \\
\hline youth & 1 & 800 & Jefl administrators & walk out & 0 & 2 & Jeff shudents & don't cancel dance \\
\hline education & 2 & 200 & Ppstooard/state & walkoutral & 0 & 2 & students & no Binnsmead culs \\
\hline education & 1 & 600 & PPS budget outs & walk outs & 1 & 2 & Ock Gr. Roos & no budget cuts \\
\hline education & 1 & & PpS budget cuts & march & 0 & 2 & EMS & no cutting our teachers \\
\hline education & 1 & $25-30,000$ & leglslature & rally/march & 0 & 2 & pol/parhohistu & fund schools \\
\hline education & 1 & & PPS & boycott call & 0 & 2 & BUF/coalition & reforms for better min edu \\
\hline educirace & 1 & 20 & PSU/state bd. Edu & protest & 0 & 2 & students & not eliminate min. scholar. \\
\hline class & 1 & 150 & Mult County & protest & 0 & 2 & & no cuts to human services \\
\hline civil nights & $\uparrow$ & 100 & City Council & pickel & 0 & 2 & & support MHRC \\
\hline transp. & 1 & & Tri Met & rallymarch & 0 & 2 & New Cir Vision & all night bus service \\
\hline \multicolumn{9}{|l|}{ SEATTLE } \\
\hline housing & 1 & 126 & sit in & SHA offices & 2 & 0 & Capitol Pk ten & heating bills too high \\
\hline housing & 1 & 150 & raily & bus bam & 2 & 0 & Shareidc & no shelter closures \\
\hline clder/abor & 1 & 1000 & march/strike & downtown & 2 & 0 & child ar wrkes & raise wages of day care \\
\hline gayhesbian & 1 & 15 & action & king $\infty$. cths & 2 & 0 & Queer Naǔon & fight to gay marriage \\
\hline gaylesbian & 1 & 10 & kiss-in & fredsnelson & 2 & 0 & queer nation & right to gay marriage \\
\hline child cribat & 1 & 300 & rally/march & downtown & 2 & 0 & Worthy wages & higher wages cc wiks \\
\hline youth/service & 1 & 20 & picket & McDonalds & 2 & 0 & Rainer b HS & yes on Ref. 43 \\
\hline yth'sveANA & 1 & 40 & rally & DHHS & 2 & 0 & Nalive Am. & fund youth home \\
\hline race/educ & 1 & & picket & Mid School & 2 & 0 & NatBiChidoevin & Close actievment gap \\
\hline youth & 1 & 100 & walk-out & CleveHS & 2 & 0 & students & no closed campus \\
\hline
\end{tabular}




$\begin{array}{lllllllll}\text { educ/race } & 1 & 20 & \text { rally } & \text { Roos HS } & 2 & 0 & \text { roos shudent treat black stu fairly } \\ \text { educhrace } & 1 & & \text { ploket } & \text { RainBeaHS } & 2 & 0 & \text { parent/studtea fire prinicipal } \\ \text { oduc } & 1 & 100 & \text { walk out } & \text { Garfield } & 2 & 0 & \text { students } & \text { keep principal }\end{array}$

\section{Urban Space}

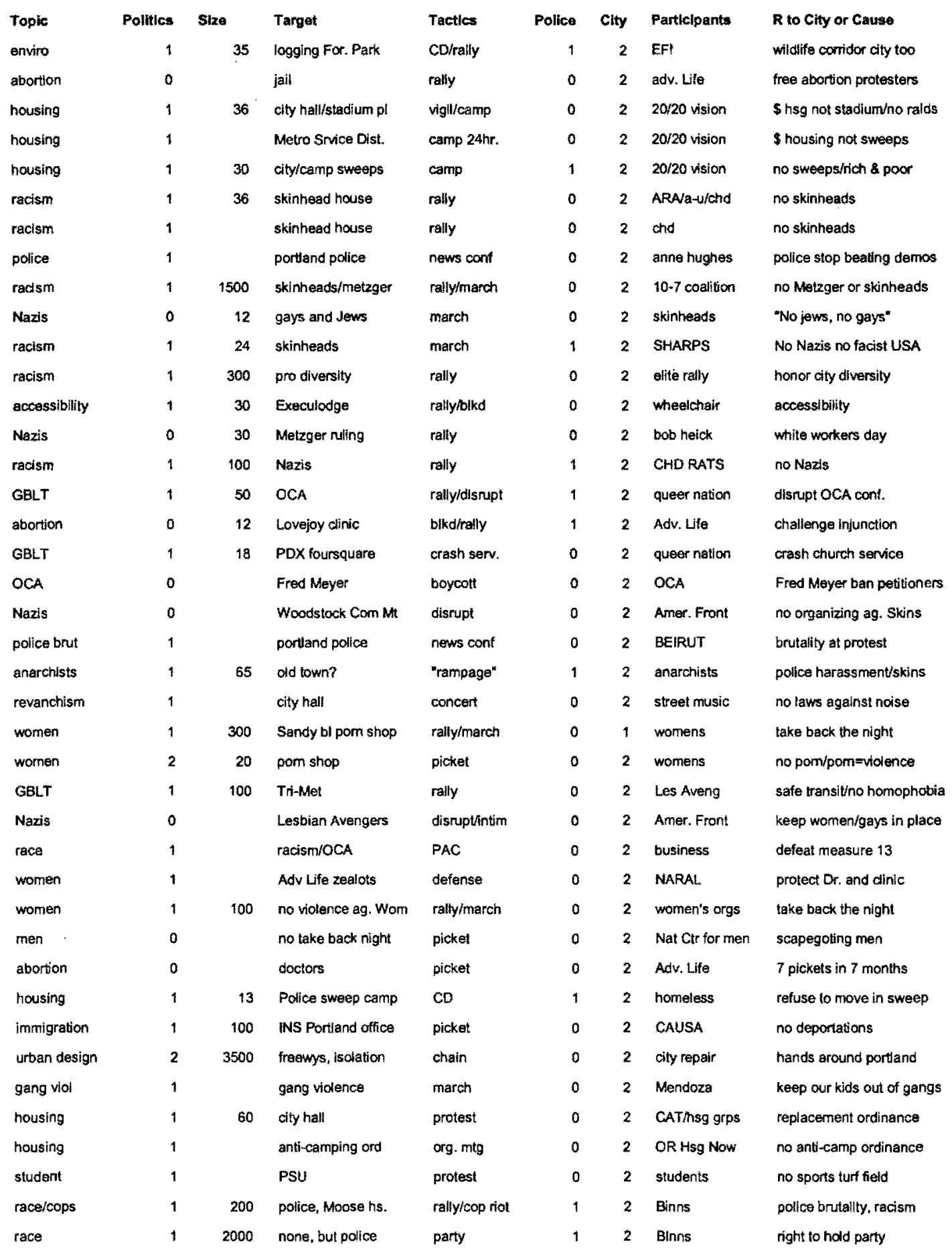




\begin{tabular}{|c|c|c|c|c|c|c|c|c|}
\hline urtan design & 2 & $12,000 ?$ & freewys, is dation & chain & 0 & 2 & city repair & hands around portland \\
\hline police brut & 1 & 150 & portand police & vigil & 0 & 2 & dickie dow fam & Hustice for dickie dow \\
\hline police brut & 1 & 400 & portland police & rally/march & 0 & 2 & oct 24 coal. & no police brutality \\
\hline housing & 1 & 50 & city hall & vigit & 0 & 2 & CAT & support replace ord. \\
\hline youth & 1 & 50 & city curfew laws & rally/march & 0 & 2 & Tinee Smith & no curfew laws \\
\hline youth & 1 & 60 & cly curfew laws & $\mathrm{CD}$ & 0 & 2 & Tinee Smith & no curfew laws \\
\hline police brul. & 1 & 20 & Portland Police & vigil & 0 & 2 & PeopolAcet & dvillain oversight of cops \\
\hline police brut. & 1 & 200 & Portiand Police & rallymarch & 0 & 2 & Lib Coll & no police brut demonstrat \\
\hline hsglythipolbr & 1 & 30 & city hall/oops & campout & 0 & 2 & hi youth & no police harassment \\
\hline \multicolumn{9}{|l|}{ SEATTLE } \\
\hline housing & 1 & 12 & rally & Publix Hotel & 2 & 0 & strond help & don't close hotel. \\
\hline housing & 1 & 75 & rally & McKay Apt & 2 & 0 & op homeloc & preserve/replace aff hsg \\
\hline race/eth $/ \mathrm{mm}$ & 1 & 60 & rally & Harborview & 2 & 0 & SEIUUW stud & right to speak Tagalog \\
\hline disablity ris & 1 & 12 & rally & UW redsq & 2 & 0 & Disab Stu com & make campus accesible \\
\hline housing & 1 & 36 & picketfieed & city hall & 2 & 0 & tnt union $/ D C$ & moratorium demo $\mathrm{LHH}$ \\
\hline race/gay/es & 1 & 50 & rally/occupy & city hall & 2 & 0 & ACT UP & no drug loitering ard. \\
\hline women & 1 & 400 & rally/march & aboretum & 2 & 0 & women & take back night \\
\hline housing & 1 & 100 & rally/march & din vacnt bl & 2 & 0 & DCIOP Home & low inc not vat heg \\
\hline housing & 1 & 24 & occupation & Arton & 2 & 1 & DCIOP Home & Arion low income hsg \\
\hline housing & 1 & & menlitytent & Afion & 2 & 0 & DCJOP Home & Arion low income hsg \\
\hline housing & 1 & & plcket & bright PI Apt & 2 & 0 & BP tenants, TU & Repairs need made \\
\hline hist preserv & 1 & 24 & rally & Music Hall & 2 & 0 & & save Music Hall \\
\hline housing & 1 & 30 & protesthent & landlord $\mathrm{hm}$ & 2 & 0 & Tenants Union & no rent increase \\
\hline housing & 1 & 15 & sleep in & occidental $p$ & 2 & 0 & Op Homestead & don't remove benches \\
\hline anti-Nazi & 1 & 400 & protestriot & Nazis on $\mathrm{CH}$ & 2 & 1 & RCP,ON,UFAF & stop bigotry \\
\hline ADDS & 1 & 30 & disrupt & moral 4 yout & 2 & 0 & ACTUP & no anti-condom dist. \\
\hline police & 1 & 100 & rally & PubSafeBlg & 2 & 0 & CoDenciv Just & pollce accountability \\
\hline race/c/police & 1 & 100 & rallymarch & $1-5$ & 2 & 1 & UW stufother & no racism/police brut \\
\hline racelclpolice & 1 & $125 \mathrm{~A}$ & riot & Cap Hill & 2 & 1 & multi youth & no justice no peace \\
\hline racelpolice & 1 & 100 & marchirally & SCCCADT & 2 & 0 & comm/stud & no felonies for rioters \\
\hline housing & 1 & 50 & occupation & Pacific Hotel & 2 & 1 & Op Homestead & tum into low inc housing \\
\hline nousing & 1 & 25 & march & Sea 1/col tow & 2 & 0 & Op Homestead & Pacific Hotel low income \\
\hline housing & 1 & 60 & rally'march & Udistrict & 2 & 0 & homeless you & youth shelter, squatter it \\
\hline housing & 1 & 25 & march & Udistrict & 2 & 1 & homeless you & squatters rights \\
\hline housing & 1 & 150 & rally & Westlake & 2 & 1 & homeless gro & no Sidran laws \\
\hline housing & 1 & 18 & protest & city coundil & 2 & 0 & homeless grp & no Sidran laws \\
\hline gaylesbian & 1 & 300 & rally & Shrinchurch & 2 & 0 & gaylesbian gr & no Lon Mabon in Sea \\
\hline housing & 1 & 75 & sit in & Occident.PK & 2 & 0 & homelessladu & no Sidran laws \\
\hline housing & 1 & 200 & march & Udistrict & 2 & 1 & homelessladu & no Sidran laws \\
\hline housing & 1 & 50 & rally/march & ConvCWest & 2 & 1 & homeless & no Sidran laws \\
\hline gaytlesbian & 1 & & picket/kissin & Epreclobby & 2 & 0 & Queer Nation & no police harss gays \\
\hline nousing & 1 & 8 & sit in & Mayors & 2 & 1 & Tenants Union & enforce reloc asst law \\
\hline housing & 1 & & sit in & city hall & 2 & 0 & civlib/hmis adv & no Sidran laws \\
\hline Houstwomen & 1 & & rally & DESC door & 2 & 0 & WHEEL & safe access to shelter \\
\hline housing & 1 & 74 & steep in & city hall & 2 & 0 & DCisungle res & don'l destroy Jungle \\
\hline housing & 1 & 30 & $\mathrm{co}$ & jungle & 2 & 1 & nomeless:DC & don't destroy Jungle \\
\hline raceipolice & 1 & & speak out & park-RainVal & 2 & 0 & youthpol acct & justice for Jackson \\
\hline women & 1 & 35 & march & Cap Hill & 2 & 0 & women grp & sale streets for women \\
\hline
\end{tabular}




\begin{tabular}{|c|c|c|c|c|c|c|c|c|}
\hline hsg/police & 1 & 200 & riot & Cap HII & 2 & 1 & homeless yth & no polica harass homel. \\
\hline hsg/police & 1 & 100 & marchirally & Cap HII & 2 & 0 & homeless yth & no police harass homel. \\
\hline housing & 1 & 20 & sit in & BroadBust & 2 & 0 & homeless yth & no Sidran laws \\
\hline housing & 1 & & sit in & Pike PI MkI & 2 & 0 & DisplaceCaal & no Sidran laws \\
\hline housing & 1 & 30 & tent city & la kingdome & 2 & 1 & SHARE & housing for the homeless \\
\hline housing & 1 & 12 & occupation & Payne Apt & 2 & 1 & Op Homestead & No demolish low ine hsg \\
\hline smoking & 1 & 36 & picket & IHOP & 2 & 0 & Youth-REACT & No smoking in IHOP \\
\hline housing & 1 & 24 & occupation & 7thPinesRo & 2 & 0 & Op Homestead & Need low income hsg \\
\hline housing & 1 & 11 & encampment & city hall & 2 & 1 & SHARE & right to sleop city hall \\
\hline youth & 1 & 100 & rally & WAMlidSen & 2 & 0 & EYES & no dress code \\
\hline police & 1 & 200 & ral/marfact & jall & 2 & 1 & & no police brutatly \\
\hline stadium & 1 & & rally & labor temp & 2 & 0 & CtforMorimpTh & no baseball stadium \\
\hline transp/police & 1 & 200 & rally/ride & DT & 2 & 0 & Critcal Mass & no police volence \\
\hline women & $i$ & & rally/march & occ park & 2 & 0 & wormen grps & no rape \\
\hline indig. Rts & 1 & 26 & rally & pot conssite & 2 & 0 & Duwamish & no digging up graves \\
\hline housing & 1 & & picket & hartoonsApt & 2 & 0 & tenents & no condo conversion \\
\hline housing & 1 & & rally & tecton mgm & 2 & 0 & tenants & no rent increases \\
\hline housing & 1 & & rally & tecton mgm & 2 & 0 & tenants & no rent increases \\
\hline gentrification & 1 & & art & ant walk & 2 & 0 & artists & no artist displacement \\
\hline race/class & 1 & 50 & car rally & rainier valley & 2 & 0 & aave our valley & no rail line on MLK \\
\hline trade/housing & 1 & 40 & squat & 914 Viriginia & 182 & 0 & & housing for prot \& poor \\
\hline
\end{tabular}

\section{Imagination}

\begin{tabular}{|c|c|c|c|c|c|c|c|c|}
\hline Topic & Polftics & size & Target & Tactlcs & Pollce & City & Participants & $\begin{array}{l}\text { R to City or } \\
\text { Cause }\end{array}$ \\
\hline nbhd. & 2 & 20 & Union Ave. Initiative & rally/ctean & 0 & 2 & sisters & $\begin{array}{l}\text { yes on king } \\
\text { Show }\end{array}$ \\
\hline women & 1 & & KATU & picket & 0 & 182 & Wom Crisis Ln & $\begin{array}{l}\text { battered men } \\
\text { Malcolm } X\end{array}$ \\
\hline racism & 1 & & Front Ave. & sign swap & 0 & 2 & Group $X$ & $\begin{array}{l}\text { Ave. } \\
\text { stop dice }\end{array}$ \\
\hline women & 1 & 300 & Andrew Dice Clay & rally & 0 & 1 & Coalition & $\begin{array}{l}\text { periromance } \\
\text { no pro gay }\end{array}$ \\
\hline antl-gay & 0 & & Oregonian, Potter & news conf & 0 & 2 & OCA & poilce/news \\
\hline GBL.T & 1 & 10000 & Measure 9 & rally & 0 & 2 & union, gay, bus. & $\begin{array}{l}\text { no on } 9 \\
\text { ant } 9\end{array}$ \\
\hline native rights & 1 & & $\begin{array}{l}\text { OR tral encamp } \\
\text { Rose festival }\end{array}$ & rally & 0 & 2 & native gros & $\begin{array}{l}\text { colonization } \\
\text { protest RF }\end{array}$ \\
\hline women & 1 & 4 & $\begin{array}{l}\text { princs. } \\
\text { Rose festival }\end{array}$ & protest & 0 & 2 & Cleveland & pageant \\
\hline women & 1 & 50 & princs. & rally & 0 & 2 & stop vio ag wm, protest RF pageant & protest OR \\
\hline women & 1 & 100 & oregonian & rally & 0 & 2 & DV advocates & $\begin{array}{l}\text { coverage DV } \\
\text { Don't } \\
\text { eliminate }\end{array}$ \\
\hline rose festival & 2 & & Rose Festival Com & picket & 0 & 2 & Junior Court & $\begin{array}{l}\text { pageant } \\
\text { think about }\end{array}$ \\
\hline housing & 1 & 6 & apathy to homeless & agltprop & 0 & $\mathbf{2}$ & PNCA stu & $\begin{array}{l}\text { homeless } \\
\text { no "chick }\end{array}$ \\
\hline women & 1 & 30 & Z100 pleasure boat & action & 0 & 2 & fern commando & boat" \\
\hline \multicolumn{9}{|l|}{ SEATTLE } \\
\hline anti-develop & 1 & & billbd alter & billboards & 2 & 1 & demo in seattle & $\begin{array}{l}\text { stadium } \\
\text { support gay }\end{array}$ \\
\hline gaydesbian & 1 & & leafletting & ingraham HS & 2 & 0 & Oufer Nation & $\begin{array}{l}\text { students } \\
\text { no beauty }\end{array}$ \\
\hline women & 1 & & rally & seafair page & 2 & 0 & myth seafair & $\begin{array}{l}\text { pagent } \\
\text { stop racist }\end{array}$ \\
\hline racism & 1 & 36 & action/rally & seatle U & 2 & 0 & SeaU students & $\begin{array}{l}\text { attilude } \\
\text { Don't chg }\end{array}$ \\
\hline free speech & 1 & & picket & KCMU & 2 & 0 & CURSE & $\begin{array}{l}\text { format } \\
\text { No Playboy }\end{array}$ \\
\hline women & 1 & & rally & Red $S q$ & 2 & 0 & students & $\begin{array}{l}\text { recritt } \\
\text { no }\end{array}$ \\
\hline AIDS & 1 & 25 & rally & SeaTimes & 2 & 0 & ACTUP & homoph.carto \\
\hline
\end{tabular}


don't show bias show 